This PDF is a selection from a published volume from the National Bureau of Economic Research

Volume Title: Economic and Financial Crises in Emerging Market Economies

Volume Author/Editor: Martin Feldstein, editor

Volume Publisher: University of Chicago Press

Volume ISBN: 0-226-24109-2

Volume URL: http://www.nber.org/books/feld03-1

Conference Date: October 19-21, 2000

Publication Date: January 2003

Title: Industrial Country Policies

Author: Jeffrey A. Frankel, Nouriel Roubini, Mervyn King , Robert Rubin, George Soros

URL: http://www.nber.org/chapters/c9776 


\section{Industrial Country Policies}

1. Jeffrey A. Frankel and Nouriel Roubini

2. Mervyn King

3. Robert Rubin

4. George Soros

\section{Jeffrey A. Frankel and Nouriel Roubini}

\section{The Role of Industrial Country Policies in Emerging Market Crises}

A search for the causes and solutions of crises in emerging markets must begin with the policies of the countries themselves. Nevertheless, policies of the industrialized countries are relevant as well. That is the topic of this chapter. It covers everything from the macroeconomic policies of the Group of Seven (G7) countries themselves, to their role via the G7 and International Monetary Fund (IMF) in managing international crises when they break out, to their role in seeking to reform the international financial architecture so as to reduce to whatever extent possible the frequency and severity of future crises. A theme throughout the chapter will be the moral hazard question: the tension between the desirability of reducing the adverse consequences of any given crisis, on the one hand, and the danger that such efforts will in the longer term encourage capital flows that are larger, more careless, and more likely to result in future crises, on the other hand.

\subsubsection{G7 Macroeconomic Policies}

Nothing that the industrialized countries do, at least in the short run, has as big an effect on economic developments in emerging market countries as

The authors wish to thank Ronald Mendoza for research assistance, and Gordon de Brouwer, Martin Feldstein, Mervyn King, Allan Meltzer, Robert Rubin, and George Soros for comments. The usual disclaimers apply with stronger force. 
their macroeconomic policies. U.S. monetary contractions, for example, were among the important causes, in a proximate sense, of the international debt crisis that began in 1982 and the Mexican peso crisis of 1994. A global easing of monetary policy in the fall of 1998 helped bring that 1997-98 round of crises to an end. Indeed, there is evidence that asset prices in emerging markets are more sensitive to short-term U.S. interest rates than are comparable asset prices in the United States itself.

Three macroeconomic variables among industrialized countries that have major short-term impact on developing countries are growth rates, real interest rates, and exchange rates. Trade policy in industrialized countries is very important as well. We consider each in turn.

\section{Monetary Policy, Fiscal Policy, and Growth}

This paper will not generally try to explain growth rates and interest rates in the industrialized countries but, rather, in this section, will look at their effects on emerging markets. Nevertheless, we begin with a parenthetical aside regarding the sources of growth. Monetary and fiscal policies are traditionally viewed as affecting real growth rates in the short run. They cannot fully explain rapid U.S. growth in the 1990s, however, or rapid Japanese growth in earlier decades. Longer-term supply or productivity determinants are clearly important. In the 1980s, many observers thought that the Japanese brand of capitalism had proven its superiority. In the 1990s, many considered that, to the contrary, the U.S. model had proven its superiority. Perhaps the attractions of Japan as a role model in the 1980s, followed by the United States in the 1990s, have had effects on developing country thinking that are ultimately more important than the immediate economic effects of growth rates in these and other industrialized countries. In any case, it is the latter topic that concerns us here.

\section{Business Cycles}

Incomes in developing countries are procyclical, rising when growth rates in the industrialized countries are strong, falling when they are not. The most visible channel of transmission is trade. When incomes in the rich world fall, their imports from developing countries fall as well. This is important because export revenue is key to the ability of poor countries to service debts. Demand for the types of goods that developing countries produce tends to be unusually procyclical (Goldstein and Khan 1985). The impact of Organization for Economic Cooperation and Development (OECD) slowdowns hits in three ways: lower quantities demanded, lower prices on world markets, and the raising of import barriers.

To take an example, the recession among industrialized countries in 1980-82 depressed prices and volumes for exports from developing countries, reversing a preceding period of boom. This, in turn, contributed to the 
international debt crisis of the 1980s. To take another example, Mexico's 1995 recovery from the peso crisis was aided by rapid U.S. economic growth. With the North American Free Trade Agreement (NAFTA) in place in 1994, Mexican exports to the United States - which were 85 percent of its total exports - were able to grow 92 percent from 1994 to $1999 .{ }^{1}$ When East Asia was hit by its currency crises in 1997-98, by contrast, recovery was hampered by the absence of economic growth in the leading regional economy, as Japan remained mired in recession. Japan's G7 partners at the time urged reflation in Tokyo; among other reasons was the need to promote growth in the rest of East Asia. For all the talk of globalization and of the irrelevance of geography, economic prospects in each region of the world are affected particularly strongly by the growth rate of the largest industrialized countries in that region.

A simple regression estimate illustrates the dependence of emerging market economies on the cyclical position of the bigger countries. Every 1 percentage point increase in $\mathrm{G} 7$ growth raises the growth rate among market borrowers an estimated 0.78 percentage points. ${ }^{2}$

\section{National Saving Rates}

Also critical to emerging markets, even for any given global growth rate, is the availability of capital, as reflected in global interest rates. The best indicator of the availability of capital is the real interest rate, that is, the nominal rate adjusted for expected inflation. An increase in the global inflation rate can for a time actually be good for developing countries. (This is true even if they are fully reflected in nominal interest rates.) The real value of preexisting debt is reduced, relative to the prices of the commodities that they produce.

More broadly, the availability of capital is determined by the balance of saving and investment. The usual presumption is that there is an excess of potentially profitable investment opportunities in the developing world, attributable to its low capital-labor ratio, relative to available domestic saving. At least, this is the presumption for those countries that have put into place the necessary preconditions for growth, such as a market economy and monetary stability, which are generally those countries that warrant the title "emerging markets." The usual presumption is also that the situation is the other way around in the industrialized world: an excess of saving over investment opportunities. As a result, the opening of capital markets results in the flow of capital from low-interest rate rich countries to high-interest rate emerging markets, to the benefit of both.

1. In current dollars. The source is IMF Direction of Trade (various issues).

2. Statistically significant at the 95 percent level. The $R^{2}$ is 0.23 . The period of estimation is 1977-99. 
Table 3.1

Trade and Current Account Balances of Developing Countries (annual average in US\$ billions)

\begin{tabular}{lrrrr}
\hline Region & $1977-82$ & $1983-90$ & $1991-96$ & $1997-99$ \\
\hline Trade balances & & & & \\
$\quad$ Developing countries & 42 & 34 & -14 & 27 \\
Africa & 3 & 5 & 5 & 2 \\
Asia & -14 & -2 & -24 & 47 \\
Middle East and Europe & 54 & 5 & 12 & 4 \\
$\quad$ Western hemisphere & -1 & 26 & -7 & -26 \\
Current account balances & & & & \\
Market borrowers & -44 & -9 & -58 & -36 \\
Developing countries & -28 & -7 & -93 & -61 \\
Africa & -15 & -3 & -10 & -15 \\
Asia & -15 & -14 & -18 & 33 \\
Middle East and Europe & 29 & -10 & -38 & -10 \\
Western hemisphere & -28 & & & -69 \\
\hline
\end{tabular}

Source: IMF, World Economic Outlook (various years).

Table 3.1 shows that developing countries have indeed been able to run current account deficits, financed by net capital inflows. However, this general pattern varies, depending on circumstances. Inflows are cut off in the aftermath of crises. As the table shows, Latin American countries were obliged to switch to large trade surpluses in 1983-90 and Asian countries in 1997-99.

Demographically, the rapid aging of the population in most industrialized countries, particularly relative to the young populations in poor countries, implies that saving rates will fall in the former over the coming decades. Logically, baby boomers in the rich countries should have been saving at high rates in recent years, and investing part of those savings in high-return emerging markets, in order to develop a good portfolio of assets to draw down in their retirement years. However, the trend in the 1980s and 1990s was in reality something quite different. National saving rates have not risen to prepare for the needs of social security deficits in the twenty-first century, but the reverse.

U.S. national saving, never high, fell sharply in the 1980s, due to an increase in the federal budget deficit, exacerbated by a fall in private saving. This kept real interest rates high in the United States, and to some extent globally, and was a negative factor in the international debt situation of that decade (e.g., Dornbusch 1985, 346-47). One view at the time was that the United States was deliberately pushing up its real interest rates (by a mix of tight money and loose fiscal policy) in order to attract capital, appreciate the dollar, and thereby put downward pressure on import prices and inflation. A particular version of this view was that the United States and Eu- 
rope were involved in a competition to appreciate their currencies and that the outcome of this ultimately futile race was high world real interest rates. The developing countries, although innocent bystanders, were said to be the victims hardest hit. The claim was that the G7 countries should enter a cooperative agreement to refrain from attempts to appreciate their currencies, and thereby lower world real interest rates, as the biggest possible contribution to helping solve the international debt problem (Sachs 1985; McKibbin and Sachs 1988, 1991). Others pointed out, however, that the relevant government officials had not in fact raised real interest rates deliberately (e.g., Feldstein 1994).

In the late 1990s the United States solved its budget deficit problem. Record deficits were converted to record surpluses. As a direct consequence, national saving rose. The overall outlook for the saving-investment balance remains a concern, however. Investment in the United States in the 1990s rose even more rapidly than national saving. The "New Economy" offers a ready explanation for booming investment. In any case, the result of the investment boom has been an ever-increasing current account deficit, financed by capital on net flowing into the United States, rather than out. The United States in essence is competing with the developing world to attract capital. The U.S. current account deficit is far larger than those of all developing countries combined.

It is possible that over the next decade a depreciation of the dollar against the euro and yen will reduce the U.S. current account deficit. However, such a trend would probably also symmetrically reduce the current account surpluses of Europe and Japan. This would mean a rearrangement of the flow of funds among industrialized countries, rather than making more capital available for developing countries.

The outlook is for low availability of saving everywhere, not just in the United States. The reason is that the demographic problem is even worse in other industrialized countries than in the United States. European progress in reducing budget deficits under the Maastrict Treaty in the 1990s is small compared to the looming liabilities represented by unfunded national retirement programs. Japan has the most rapidly aging population of all, and the fiscal expansion of the late 1990s has already pushed up previously low budget deficits and debt levels in that country. Nowhere are industrialized countries fully taking advantage of the opportunity to prepare for the coming retirement boom by saving heavily in their high-earning years and investing at substantial levels in younger developing countries (e.g., B. Fischer and Reisen 1994).

\section{The Role of Interest Rates in the United States and Other Major Countries}

On a yearly or monthly basis, fluctuations in interest rates (whether real or nominal) do not reflect changes in long-term fundamentals such as de- 
mographics but, rather, reflect shorter-term factors. These include monetary policy and changes in attitudes toward liquidity and risk. Easy monetary policy among the industrialized countries in the 1970s meant low real interest rates; developing countries thus found it easy to finance their current account deficits, for example, by borrowing petrodollars recycled through banks in London and New York. The U.S. monetary contraction of 1980-82, although it was eventually successful at reversing the high inflation rates of the 1970s, initially pushed up nominal and real interest rates sharply. This, as already noted, helped precipitate the international debt crisis of the 1980s.

In the early 1990s, interest rates in the United States and other industrialized countries were once again low. Investors looked around for places to earn higher returns and discovered the emerging markets. There began what was in many ways the greatest flow of capital to developing countries in history. (The pre-World War I flow of finance from capital-rich Great Britain to land-rich Argentina, Australia, and Canada still holds the record when expressed as a percentage of income. However, the flows of the 1990s were far larger in absolute terms, and more of a global phenomenon.)

During 1992-94, Calvo, Leiderman, and Reinhart (1993, 1994) - and some other authors at the World Bank and IMF — produced a series of research papers examining the new capital flow phenomenon. They enumerated the possible underlying factors, attempted econometric estimation, and generally came to a surprising conclusion: the most important identifiable factors behind the flows were U.S. interest rates and other macroeconomic variables external to the emerging market countries. Capital was heading South because low rates of return were on offer in the North.

This was a surprising conclusion because the more common belief at the time was that domestic factors within the emerging market countries were responsible, particularly promarket policy reforms: monetary stabilization, privatization, deregulation, and the opening of economies to both trade and capital flows. Other candidate explanations were reduction of the existing debt burden under the Brady Plan, which had been launched in 1989 with Mexico as the first case, and institutional innovations in the investor community that made diversification into emerging markets more convenient, such as country funds, American Depository Receipts, and Global Depository Receipts. However, the econometric studies reached the rough consensus that external macroeconomic factors were a major cause, perhaps the major cause, of the increased demand for assets in emerging countries.

Calvo, Leiderman, and Reinhart (1993, 136-37) found that "foreign factors account for a sizable fraction (about 50 percent) of the monthly forecast error variance in the real exchange rate ... [and] . . . also account for a sizable fraction of the forecast error in monthly reserves." Chuhan, Claessens, and Mamingi (1998) estimated that U.S. factors explained about 
half of portfolio flows to Latin America (although less than country factors in the case of East Asia). Fernandez-Arias (1994) found that the fall in U.S. returns was the key cause of the change in capital flows in the 1990s. Dooley, Fernandez-Arias, and Kletzer (1994), in a study of the determinants of the increase in secondary debt prices among eighteen countries, concluded that "International interest rates are the key factor." It is worth emphasizing that all these papers were written before the Mexican crisis of December 1994, during a period when most analysts in the investment community believed that the capital inflows were likely to continue because they were based on local promarket reforms. ${ }^{3}$

One study of early warning indicators among 105 countries over the period 1971-92 found that foreign variables were among those statistically significant in predicting the probability of a currency crash. Short-term world interest rates were important. ${ }^{4}$ A 1 percentage point increase in interest rates was estimated to raise the probability of a currency crash by about 1 percentage point per year. The combination of high indebtedness (ratio of debt to gross domestic product [GDP]) and an increase in world interest rates was particularly likely to lead to trouble. (OECD output growth had an effect on the crash probability that was less clearly significant.) Similarly, Eichengreen and Rose (2001) found that foreign real interest rates were significant in predicting banking crises as well among emerging market countries.

Calvo, Leiderman, and Reinhart (1993) - two years before the Mexican peso crisis - warned that "The importance of external factors suggests that a reversal of those conditions may lead to a future capital outflow." The warning was little heeded at the time. Nevertheless, the prediction came true in 1994, when the Federal Reserve raised interest rates seven times, a total of 3 percentage points (starting 4 February, and counting the last one on 1 February 1995). Foreign purchases of peso assets came to a halt. The assassination of Mexican presidential candidate Luis Donaldo Colosio and a period of other political disturbances also began in early 1994, so it is difficult to disentangle the causes. Both sets of factors undoubtedly played a role, along with domestic macroeconomic policies. In the absence of do-

3. A summary of details regarding the data and statistical techniques used in these four studies appears in Frankel and Okongwu (1996). (That paper also presents more econometric evidence of a heavy influence of U.S. interest rates on portfolio capital flows and local interest rates; these results go up to December 1994 and thus include the adverse effects of U.S. interest rates in 1994 on the Mexican peso crisis.) For a more recent study that finds a significant role of U.S. interest rates in determining capital flows to emerging markets, see Mody, Taylor, and Kim (2001). They, like the authors of some of the other studies, find that the U.S. real growth rate may be at least as important a determinant as U.S. interest rates.

4. Computed as an average of interest rates in six industrialized countries, with weights determined by shares in the debt of the developing country in question (Frankel and Rose 1996). Other variables were also statistically significant in predicting currency crises. Some of the most important concerned the composition of the preceding capital inflows, a topic relevant for the reform of the international financial system. 
mestic adjustment during the course of the year, reserves hemorrhaged in December, leading to the collapse of the peso. Regardless of what one thinks of the deeper causes of the problem, or of the need for vigilance by the Federal Reserve on inflation, the increases in U.S. interest rates were among the proximate causes of the Mexican crisis.

There are a number of channels whereby foreign interest rates affect emerging markets. First, high global real interest rates tend to depress, not just real economic activity in general, but the prices of the basic commodities produced by many developing countries in particular. Second, high interest rates directly raise debt service costs. Particularly where debt is shortterm, or with floating interest rates tied to London Interbank Offered Rate (LIBOR) or the U.S. treasury bill rate, an increase in world interest rates translates immediately into a higher interest bill for debtor countries. Thus, the ratio of debt service to exports suffers as a result of both an increase in the numerator and a decline in the denominator.

In recent years the emphasis has shifted from the ability of debtors to service bank loans out of export receipts - or to roll them over — to the ability of emerging markets to retain investor confidence and thereby attract enough new inflows to meet maturing bonds. High interest rates in industrialized countries make investments in emerging markets less attractive. At first, diminished capital inflows may show up as only a gradual loss of reserves. In a speculative attack, however, the country loses the confidence of the international financial markets unless it raises interest rates sharply, and sometimes even if it does.

The new abundance of data on securities prices in emerging markets over the last fifteen years makes it easier to examine statistically the sensitivity to financial conditions in the industrialized countries. Table 3.2 shows the sensitivity of emerging market securities prices and growth to G7 interest rates. An increase in the $\mathrm{G} 7$ real interest rate (weighted average of the countries' lending rates, adjusted for one-year lagged inflation) has a negative effect on the composite index of emerging market equities. The effect of a 1 percentage point increase in the real interest rate is an estimated 0.17 drop in the log composite index (17 percent). The effect on Latin America considered alone is higher, an estimated 0.42 drop, and on Asia is lower, an estimated $0.11 .{ }^{5} \mathrm{An}$ increase in the real U.S. federal funds rate has an effect on emerging equity markets that is comparable in magnitude — greater in magnitude, in the case of Latin America - than the effect on U.S. equity markets. The Emerging Market Bond Index (EMBI) Global, which tracks returns for U.S. dollar-denominated debt instruments issued by emerging market sovereign and quasi-sovereign entities, also appears to fall as $\mathrm{G} 7$ lending rates

5. These effects at first appear significant statistically, but the significance levels drop sharply when one corrects for high serial correlation. The equations were estimated from annual IFC global data, compiled by the Standard \& Poor's Corporation, over the period 1984-99. 


\begin{tabular}{|c|c|c|c|}
\hline & Coefficient & Standard Error & $R^{2}$ \\
\hline \multicolumn{4}{|l|}{$\begin{array}{l}\text { IFC global index of equities regressed } \\
\text { against the } G 7 \text { real lending rate }\end{array}$} \\
\hline Composite & -0.17 & 0.02 & 0.28 \\
\hline Asia & -0.11 & 0.03 & 0.09 \\
\hline Europe, Middle East, and Africa & 0.03 & 0.06 & 0.00 \\
\hline Latin America & -0.42 & 0.03 & 0.58 \\
\hline \multicolumn{4}{|l|}{$\begin{array}{l}\text { IFC global index of equities regressed } \\
\text { against the U.S. real Federal funds rate }\end{array}$} \\
\hline Composite & -0.11 & 0.02 & 0.19 \\
\hline Asia & -0.07 & 0.02 & 0.08 \\
\hline Europe, Middle East, and Africa & 0.15 & 0.05 & 0.15 \\
\hline Latin America & -0.29 & 0.02 & 0.50 \\
\hline $\begin{array}{l}\text { U.S. Standard \& Poor's } 500 \text { Index regressed } \\
\text { against the U.S. real Federal funds rate }\end{array}$ & -0.16 & 0.11 & 0.04 \\
\hline $\begin{array}{r}\text { Emerging Markets Bond Index (EMBI) } \\
\text { global composite regressed against }\end{array}$ & & & \\
\hline G7 real lending rate & -0.34 & 0.03 & 0.63 \\
\hline $\begin{array}{l}\text { EMBI global composite regressed against } \\
\text { the U.S. real Federal funds rate }\end{array}$ & -0.23 & 0.07 & 0.14 \\
\hline \multicolumn{4}{|l|}{$\begin{array}{l}\text { Developing country growth regressed } \\
\text { against the } G 7 \text { real interest rate }\end{array}$} \\
\hline Market borrowers & -0.39 & 0.27 & 0.09 \\
\hline Africa & -0.35 & 0.19 & 0.14 \\
\hline Asia & -0.04 & 0.21 & 0.00 \\
\hline Middle East and Europe & -0.20 & 0.22 & 0.04 \\
\hline Western hemisphere & -0.77 & 0.23 & 0.35 \\
\hline
\end{tabular}

Source: IFCG from Standard \& Poor's, EMBI from JPMorgan, and interest rates from the IMF (International Financial Statistics [various years] and World Economic Outlook [various years]).

Notes: All interest rates are expressed in terms of real percentage points, and all indexes are expressed in $\log$ form. Regressions with EMBI use monthly data from January 1995 to December 1999 (60 observations). Regressions with IFCG use monthly data from January 1985 to December 1999 (180 observations), except for regressions on EMEA which use monthly data from January 1996 to December 1999 (48 observations). Regressions with S\&P 500 use monthly data from January 1996 to December 1999.

increase. A 1 percent increase in the $\mathrm{G} 7$ real interest rate coincides with an estimated 34 percent decline in the EMBI.

Real interest rates may also have a negative effect on real growth rates in emerging markets. The effect is only statistically significant in the case of Western Hemisphere countries, however: an effect estimated at 0.77 percent in lost growth for every one percentage point increase in G7 real interest rates.

There is much less reason to think that foreign interest rates played an 
important role in the arrival of the East Asian currency crisis in Thailand in July 1997 as compared to earlier crises. There had been a quarter-point increase in the federal funds rate on 25 March $1997,{ }^{6}$ and later came the first hints of a possible end to the Bank of Japan's policy of low nominal interest rates. However, these developments were relatively minor. ${ }^{7}$

The passing of the crises of 1997-98, on the other hand, can be associated with monetary easing in the industrialized countries. August 1998 saw a second round of crises, with the Russian devaluation and default, and subsequent widespread contagion, including trouble for the real in Brazil and trouble for Long-Term Capital Management (LTCM) in New York. The G7 responded in a multifaceted manner (to be discussed below). The most potent arrow in the G7 quiver was interest rates. One view is that each country's central bank would have been reluctant to cut interest rates on its own, for fear of capital outflows and currency depreciation. U.S. leadership could signal the move to a new easier-money global equilibrium. President Clinton, in a speech on the emerging market crises at the Council on Foreign Relations in September, said that the balance of risks in the global economy had shifted from inflation to deflation. ${ }^{8}$ The Federal Reserve Board subsequently voted to lower the federal funds rate three times in the fall of 1998 (end-September, mid-October, and mid-November). Virtually every major central bank in the world followed suit. Within a few months the financial crisis had passed. There can be little doubt that the monetary easing played an important role. (Admittedly, it took longer for the real economies to recover in many of the emerging markets.)

Indeed, it is possible that the monetary easing of late 1998 is the answer to a puzzle that the case of Brazil otherwise poses. The conventional wisdom to come out of the crises of 1994-98 was that the worst thing a country can do, once capital inflows turn to capital outflows, is to delay an inevitable devaluation. Vulnerable emerging markets must choose between rigid institutional fixes for the exchange rate, for those countries willing to give up monetary autonomy, or else increased flexibility (see Edwards, chap. 1 in this volume). If they stubbornly cling to a peg or other exchange rate target until they have lost most of their reserves, the devaluation when it comes will be very costly, resulting in a loss of confidence and a severe recession. This is what happened to Mexico, Thailand, and Korea. Brazil stalled throughout the second half of 1998, hoping that capital outflows

6. A few observers, apparently including some at the New York Federal Reserve, have implicated the Federal Reserve's one-quarter point move (which could have been the beginning of a new trend, even though it turned out not to be) in the subsequent withdrawal of international investors from Thailand (Woodward 2000, 188).

7. World interest rates do not figure prominently in the more recent statistical studies of crisis predictors, probably because they were not close to the scene of the crime in 1997 when it came time to round up the suspects (e.g., Goldstein, Kaminsky, and Reinhart 2000).

8 . Waldman $(2000,231)$. This was the one time that the administration came close to commenting on monetary policy. 
would abate and postponing the devaluation in precisely the way that conventional wisdom warned against. However, when the Brazilian devaluation materialized in January 1999, the feared adverse effects did not. Brazil's growth increased in 1999, led by newly competitive exports, as in the traditional textbook view, but in contradiction to the new conventional wisdom. Furthermore, unlike the contagions of the preceding two years, the Brazilian devaluation had no serious repercussions outside the region. Why the contrast with the preceding crises? There are a number of possible explanations, but one major factor was the easing of liquidity by the major central banks and the restoration of global confidence that had taken place over the intervening five months.

Between the spring of 1999 and the spring of 2000, the Federal Reserve once again raised interest rates, in response to fears of overheating in the U.S. economy. Spreads on some emerging market debt, along with spreads on low-rated U.S. corporate debt, subsequently rose to levels reminiscent of the fall of 1998. This renewed flight of investors away from risk contributed to tremendous financial pressure on Argentina and Turkey in November 2000. It is possible that the movement in U.S. interest rates again contributed to these events.

As with the preceding crises in other countries, macro policies in the industrialized countries were not the most important cause of the problems in Argentina and Turkey. In Argentina an overvalued currency, together with fiscal imbalances and large domestic and external debt refinancing needs, made investors nervous about the economic prospects of the country. In Turkey, structural weaknesses and scandals in the banking system were particularly relevant. In both cases, the turmoil in the currency and domestic bond markets was controlled in late 2000 through a combination of a stronger program of policy adjustment joint with packages of exceptional financing from the IMF (activation of the Supplemental Reserve Facility) and other official creditors; but the peg in Turkey collapsed in February 2001.

\section{G7 Exchange Rates}

Regardless of what choices they make for their own currencies, even if they opt for a fixed exchange rate, small countries can do nothing about variability in the exchange rates among the dollar, yen, euro, and other major currencies. To peg to one currency is to float against the others. At a minimum, this variability complicates their lives. However, some observers would protest that this description understates the problem. They attribute crises in emerging markets, in part, to fluctuations in $\mathrm{G} 7$ exchange rates, and they propose international plans to stabilize them.

The strong appreciation of the dollar in the early 1980s raised the value of the debt obligations of Latin American countries relative to their export proceeds. The destinations of the exports were more diversified geographi- 
cally (especially in Europe) than were the origins of the loans, which were mostly denominated in dollars. Thus the dollar appreciation was another of the contributing factors that precipitated the debt crisis.

\section{Did a Rise in the Yen-Dollar Rate Cause the East Asia Crisis?}

Standard accounts of the origins of the East Asia crises that began in mid-1997 also feature prominently the 40 percent appreciation of the dollar against the yen over the preceding two years. ${ }^{9}$ The East Asian countries are said to have lost international competitiveness because they were pegged to the dollar, which led to large current account deficits, loss of reserves, and ultimately the crises.

This argument is in some ways overstated. In the first place, the appreciation of the dollar against the yen was only a reversal of a sharp depreciation of the dollar that had preceded it in the early $1990 \mathrm{~s} .{ }^{10}$ In the second place, although the competitiveness effects were real enough, there was also a debt denomination effect that could go the other way. Not all foreign debt is denominated in dollars. The use of the yen in Asian finance increased sharply in the 1980s and was widely heralded at the time. The southeast Asian countries, in particular, doubled the share of their debt denominated in yen from 1980 to 1987, surpassing the share denominated in dollars. For this reason, when Southeast Asians in the late 1980s pleaded for a reduction in yen-dollar volatility, citing fears of severe financial stress, they were worried about appreciation of the yen, not depreciation! ${ }^{11}$

Admittedly, the currency denomination of Asian debt reversed to some extent in the 1990s. By 1996, the dollar share had reached 41.5 percent, and the yen share had declined to 24.0 percent for the region overall. However, the situation varies substantially from country to country. Toward one end of the spectrum, two of the three crisis countries, Thailand and Indonesia, still had more yen debt in 1996 than dollar debt. For Thailand and the Philippines, the importance of the Japanese market in exports was well below the importance of the yen in their debt. For Indonesia, the debt shares corresponded roughly to the trade shares. Toward the other end of the spec-

\section{9. $120 / 85=1.41$.}

10. The yen-dollar rate, which peaked near 147 in 1998, had also been at that level in 1990, and far higher than that before 1986.

11. It should also be noted that these figures apply only to long-term debt. Figures on the currency denomination of short-term loans are not available for all countries, but they were probably more often dollar-denominated than was long-term debt. (For Korea, short-term debt denominated in dollars represented 91 percent of the $\$ 19.9$ billion total, yen debt 7 percent, and DM debt 1 percent. The data include debt for all banks or countries that participated in the January 1998 rollover agreement.) It should also be noted that a comparison of debt shares and export shares tells the direction of effect on the debt-export ratio only if export quantities are fixed in terms of the partner's currency. It ignores, for example, competition with Japanese producers in other markets. 
trum, Malaysia and, especially, China had dollar debt shares that were higher than their yen debt shares and higher than the relative importance of the dollar area (taken to be the western hemisphere) in their exports. Consequently, these may be the countries that had the most to lose from yen depreciation. This may help explain why China opposed further depreciation of the yen against the dollar in June 1998. A desire to placate China was reported to be the motive behind yen purchases at that date, the first time the Clinton Administration had intervened to resist dollar strength. (Other reasons were important as well, however.)

As recently as the mid-1990s, fears of the consequences in Asia of a yen appreciation were associated with the "yen carry" trade. When Japanese interest rates fell almost to zero, speculators began borrowing heavily in yen and investing the proceeds in dollar-denominated securities that paid higher interest rates, the practice known as yen carry trade. The difference in interest rates is pure profit if the exchange rate remains unchanged, but some were concerned that Asian speculators were underestimating the dangers of future yen appreciation, which could impose huge losses if it occurred. It is ironic that during the two years leading up to the Asia crisis, the yen-dollar movement was in the opposite direction, and the yen carry trade was temporarily very profitable. ${ }^{12}$

To summarize the point, the depreciation of the yen between 1995 and 1997 helped the Southeast Asian debtors on the debt side, by reducing debt service costs and improving their balance sheet, even while it hurt them on the trade side. If the debt service ratio is a relevant indicator, then the depreciation of the yen against the dollar was actually good for countries like Thailand, where the share of debt denominated in yen exceeded the share of exports going to Japan, but bad for countries like China, where the reverse was true. We emphasize the implications for yen-denominated debt only because it has been completely neglected in most commentary. ${ }^{13}$

One interpretation is that large swings of the yen-dollar rate in either direction generate stress in the region, that volatility per se is the problem. If exchange rates among the major industrialized countries were stabilized, it would no doubt simplify the lives of everyone else. The key question, then, becomes whether this stabilization can be accomplished in practice, or at what sacrifice.

12. Such fears indeed became relevant in the fall of 1998 , when the yen appreciated sharply.

13. The Frankel and Rose (1996) study looked for evidence of the debt exposure effects. The question was whether the probability of a currency crash increases in a country when there is an appreciation of the major currencies in which a high proportion of that country's debt is denominated. Even though other measures of the composition of capital inflows or external conditions showed up as significant indicators (e.g., the share of short-term debt and foreign interest rates), this measure of currency composition and movements in G3 exchange rates did not show up with the sign expected. Perhaps the trade composition channel on average outweighs the debt composition channel. 


\section{The Proposal for a Group of Three Target Zone}

Such commentators as Bergsten, Williamson, and Volcker have urged the Group of Three (G3) countries to stabilize exchange rates, for example, through a target zone arrangement. One of their arguments is precisely that excessive exchange rate volatility among the dollar, yen, and euro plays a role in emerging market crises. ${ }^{14}$ Most economists, however, believe that exchange rates reflect monetary conditions in the corresponding countries and other economic fundamentals such as productivity, that the G3 countries have no means for stabilizing their exchange rates other than devoting monetary policy to the task, and that they neither should nor will subordinate domestic priorities to such international goals (e.g., Clarida 2000).

We believe that the view that all exchange rate fluctuations are attributable to monetary policy and other economic fundamentals is too simple. Sometimes the exchange rate moves for reasons unrelated to fundamentals, and sometimes governments can combat such moves by public statements or intervention in the foreign exchange market, even if these actions do not change monetary policy (Dominguez and Frankel 1993). Intervention in support of the dollar in mid-1995 was instrumental in reversing the preceding depreciation of the dollar, and intervention in support of the yen in mid1998 may also have played a role in reversing the depreciation of the yen.

Nevertheless, the majority's policy conclusion stands. If the G3 or G7 countries were to proclaim an explicit target zone for the major currencies, it would not be long before speculators were testing the limits, a challenge in which they would eventually be successful. We do not view a target zone among the $\mathrm{G} 3$ currencies as a practical reform to help avert crises in emerging markets.

\section{Industrial Country Trade Policies}

International trade is an important engine of economic development even in the best of times. ${ }^{15}$ When a developing country undergoes a balanceof-payments crisis, the ability to increase exports rapidly (or, more generally, to increase production of internationally traded goods) is critical to its resolution. For many of the recovering victims of recent emerging market crises, an improvement of the trade balance led the stabilization of confidence on the part of international investors. These countries succeeded in switching from large deficits to surplus in the span of a couple of months. Unfortunately, this initial "improvement" in the trade balance usually takes the form of a sharp drop in imports due to domestic recession. It takes

14. See, for example, the dissenting statement "On Target Zones for the G-3 Currencies," by Paul Allaire, C. F. Bergsten, and others including George Soros and Paul Volcker, in Council on Foreign Relations (1999), pages 125-29. They believe there can be no serious reform of the architecture regarding emerging markets without a plan to stabilize the dollar, yen, and euro.

15. Econometric evidence and further references are available in Frankel and Romer (1999). 
longer before the devaluations have the intended effect of promoting exports. Only over the subsequent few years does growth in exports lead the recovery of economic activity.

In the past, the highest barriers to international trade have been those put in place by the developing countries themselves. However, most of these countries, at least most that qualify as emerging markets, went a long way in the 1990s toward reducing trade barriers. Industrialized countries retain substantial barriers to exports from developing countries, and there is little evidence of a downward trend. True, the rich countries in the Uruguay Round of multilateral negotiations to liberalize trade promised to phase out over time their quotas on apparel and textiles, two of the most important sectors for developing countries, and to end the previous exemption of agriculture from multilateral negotiations. The phasing-out has yet to begin, however, and there is even less sign of any intention to liberalize with respect to those agricultural products, such as sugar and rice, that are of particular interest to developing countries.

In fact, many rich-country politicians, in the wake of both the 1982 and 1997 crises, responded to increases in their constituents' purchases from developing countries by supporting new protection of domestic markets. They either did not realize or did not care that shutting off these exports was inconsistent with calls on emerging market countries to obey the rules of the marketplace and to generate the foreign exchange needed to service their debts. Barriers to the export of steel from Brazil, Korea, and Russia were perhaps the strongest examples.

What are the chances that a future World Trade Organization (WTO) round will address the export interests of the developing countries? Even though decisions in the General Agreement on Tariffs and Trade (GATT) and WTO are technically made by consensus, with each country having an equal vote, it is inevitable that some players in practice count far more than others. The pattern in past GATT rounds has been that cut-and-thrust exchange between the United States and Europe has dominated the negotiations, and when those two powers have come to some agreement, the rest of the world generally falls into line. Other countries have had little influence over the agenda. Little vote was given to the developing countries, largely because they had little in the way of lucrative concessions to offer the rich countries.

Increasingly, however, the developing countries are important players, at least collectively. Asia and Latin America now constitute major markets. Under the new rules agreed upon in the Uruguay Round, they, like other WTO members, are generally no longer able to opt out of aspects of an agreement ${ }^{16}$ or to block decisions by panels under the dispute settlement

16. Bhagwati (1998). The requirement that WTO members must adhere to all negotiated obligations as a "single undertaking" still has exceptions for the poorest developing countries. Also, two areas, government procurement and civil aviation, remain under "plurilateral accords" of the WTO (Schott 1998, 3). 
mechanism. Furthermore, in the Uruguay Round developing countries were asked in the area of Intellectual Property Rights to put energy into enforcement of a set of rules that, whatever their economic justification, benefit rich-country corporations and not them. For all these reasons, in the next round of WTO negotiations their interests will have to be taken into account. In addition to liberalization of textiles trade, this would also mean protection against arbitrary antidumping measures, if the United States would agree (and liberalization in agriculture, if Europe would agree). If a new round has nothing to offer the developing countries, they might this time try to block it.

Textiles and apparel are typically the first rung of manufacturing exports for poor countries seeking to climb the ladder of development. Rich countries agreed in 1995, under the Uruguay Round, to phase out over the next ten years the quotas that under the Multi Fiber Agreement (MFA) have long kept the textile sector highly protected. An acceleration of the schedule is the simplest concession to offer the poor countries in exchange for the many demands being placed on them. But little liberalization has occurred to date. The difficult time the U.S. administration had in 1998-99 in convincing Congress to support the elimination of barriers to apparel exports even from Africa and the Caribbean is revealing. China's accession to the WTO alarms some with the prospect of a huge increase in the global supply of inexpensive textiles and apparel. There are grounds for skepticism, given domestic politics in the United States and other rich countries, regarding whether the MFA phase-out that was promised in 1995 will actually happen. If rich countries fail fully to deliver on this promise, it is hard to see what incentive developing countries have to go along with a new round or even to carry out their Uruguay Round commitments in the area of Intellectual Property Rights (Wang and Winters 2000; Subramanian 1999).

Antidumping (AD) measures are on the upswing. In 1999, 328 AD cases were launched, up 41 percent from 1998, and more than double the rate in 1995 (The Economist, 22 April 2000). The name antidumping makes the measure sound like it has something to do with antitrust enforcement against predatory pricing; thus it gives the press and public the impression that these measures are a tool to combat trade distortions and increase competition. On the contrary, they have nothing to do with predatory pricing: they suppress competition rather than defending it, and they are among the costliest of trade barriers. ${ }^{17}$

The use of AD measures increased rapidly in the United States in the 1980s and 1990s, because firms hit by increased imports found it much easier to gain protection under the AD laws than under the safeguard laws.

17. The enactment of antidumping duties means import quantities on average fall by almost 70 percent and import prices rise by more than 30 percent (Prusa 2000). 
Their use has subsequently increased rapidly in other countries as they emulate and retaliate against the United States. An attempt to rein in the indiscriminate use of $\mathrm{AD}$ would rank near the top of the economist's wish list of priorities for the next round of multilateral negotiations. (It could be coupled with some steps toward a multilateral competition policy, to reassure those who are under the illusion that the AD laws have some procompetition value.) Unfortunately, the United States is unlikely to agree to the inclusion of this issue.

Nothing requires waiting for a new WTO round to reduce trade barriers against emerging markets. In the aftermath of the 1997-98 crises, the major industrialized countries could have committed collectively to keeping their markets open to exports from other countries. However, even an initiative to commit the rich countries to end quotas and duties on their imports from the poorest countries, at the IMF and World Bank meetings in the spring of 2000, ran into the inevitable political roadblocks (e.g., "Spring Meetings Fail to Burst into Blossom," Financial Times, 19 April 2000).

To recapitulate the conclusions of section 3.1.1, movements among the industrialized countries in interest rates and, to a lesser extent, exchange rates, can have important influences on emerging markets. Inflationary monetary policies among industrialized countries might temporarily help emerging markets but would also do substantial damage to the industrialized countries. Sustaining their own growth and keeping their trade barriers low may be the most important things that industrialized countries can do to maximize growth in emerging markets and minimize the frequency and severity of crises. At the end of the day, providing open markets for goods and services may be more important than all the institutional reforms that have been proposed regarding the financial architecture.

\subsubsection{Crisis Management}

There is a vast array of organizations and venues where national representatives deliberate over measures that affect emerging markets, whether the measures are in the category of short-term macroeconomic policy coordination or long-term reform of the international financial architecture to reduce the frequency of future crises and resolve more efficiently those crises that do occur. When a crisis breaks out, these mechanisms become particularly important as a mode of crisis management, that is, as a means to minimize adverse effects.

\section{Modalities of Coordination}

The governments of the industrialized countries dominate the discussions in these meetings. One defense against wider inclusion is that speed and decisiveness are important in crisis management, which requires a small number of participants. Moreover, groupings of small countries re- 
ceive a voice through proportionate representation, as on the IMF Board of Executive Directors, with votes roughly proportionate to economic importance. One rationale for participation by the IMF managing director in G7 finance ministers' meetings is as a representative of the smaller countries. (The Russian president is now included in Group of Eight (G8) summit meetings; but the country is not invited to participate in G7 meetings on financial topics.)

Some emerging market countries are large. By 1996, China and Brazil had in economic size surpassed Canada, the seventh largest country in the G7, even when their GDPs are valued at current exchange rates. In addition, India, Mexico, and Indonesia had done so if one evaluates GDPs by purchasing power parity (PPP). ${ }^{18}$ Switzerland, Belgium, and Sweden are in the Group of Ten (G10), but by 1996 China, Brazil, Korea, Russia, India, Argentina, and Mexico had passed Sweden, even at current exchange rates (as had many others, if one evaluates GDPs at PPP rates). After the crises of 1997-99, the emerging markets all slipped in the rankings. In 1999 only China remained ahead of Canada, by the PPP measure; Brazil, Mexico, India, Korea, Taiwan, and Argentina remained larger than the smaller members of the G10.

The fact that the G7 (United States, Japan, Germany, France, United Kingdom, Italy, and Canada) and G10 economies are overall larger than the developing countries does not explain the membership in the $\mathrm{G} 7$ or G10. ${ }^{19}$ Another relevant principle that explains these power relationships is that creditors generally have influence over debtors. ${ }^{20}$ While the United States (and Italy) are net debtors internationally, in the context of crises they are net lenders to crisis countries and to the international financial institutions. Perhaps the most succinct description of the membership of the G7 is that it represents the victors in the Cold War, much as the membership of the United Nations (UN) Security Council was chosen to represent the victors of World War II. Moreover, the growing economic importance of systemically important emerging market economies is behind the recent drive to create international groupings, such as the Group of Twenty (G20; to be

18. National incomes are properly evaluated at purchasing power parity rates if one is interested in the real incomes of the population. For purposes of evaluating weight in international power relationships and responsibilities, it is more appropriate to evaluate at actual exchange rates. For example, one might care how many F-16s a country can buy, how much money it can offer a small island nation for the right to put a naval base there, or how much it can contribute to a multilateral peacekeeping operation, famine relief, debt forgiveness, or the New Arrangements to Borrow. In each case, current exchange rates are the right measure, as variable as they are.

19. This group has actually eleven members: the G7 plus the Netherlands, Belgium, Sweden, and Switzerland.

20. This truism is somewhat at odds with another favorite and wise aphorism: "If you owe your banker a million dollars, you have a problem. If you owe your banker a billion dollars, he has a problem." 
discussed below), that include these countries along with the advanced industrialized countries.

\section{Finance Ministers and Deputies}

The G7 finance ministers, their deputies, and deputies' deputies play a crucial and central role in crisis management. This role takes three central forms:

1. Consultations and cooperation during crises of systemically important countries to resolve such crises (Mexico, Thailand, Korea, Indonesia, Russia, Brazil);

2. Joint work to develop G7 policies and doctrine on how to prevent and resolve financial crises (as in the work on the reform of the international financial architecture);

3. Crisis management for nonsystemic countries requiring external debt rescheduling or restructuring (Pakistan, Ukraine, Ecuador, Romania) and formulation of official doctrine on private-sector involvement in crisis resolution.

Crisis management and resolution as well as formulation of policies regarding private-sector involvement (PSI) involves a number of other institutions, namely, the IMF, the Paris Club, the Bank for International Settlements (BIS) and G10 central bank governors, national security agencies and heads of state and, more recently in a more limited consultative forum for discussing general PSI policies, the G20 group. The role of these other players will be discussed below, after the G7.

There are a variety of views among the $\mathrm{G} 7$ on how to deal with these three sets of issues, but the $\mathrm{G} 7$ has been able to reach a solid consensus on most questions. Indeed the work on crisis management and architecture reform has been very cooperative. On the question of how to deal with systemic liquidity cases, Europeans have been slightly more wary than the United States of providing large packages of official money out of concerns about moral hazard. Some Europeans have also correspondingly been somewhat more hawkish in support of more coercive ways to involve the private sector in crisis resolution, including stronger sympathy for the idea of debt standstills. The United States has stressed the importance of maintaining some degree of flexibility to address each case on its own merits rather than relying on rigid or formal rules, including using large official packages when appropriate. The United States has shown greater support for the idea of corner solutions in exchange rate regimes (either a firm fixed or flexible one, as opposed to intermediate regimes) than the Europeans and the Japanese, and less sympathy for some suggestions to restrict international capital flows (both inflows and outflows). Some Europeans and Japanese are also more sympathetic toward ideas regarding direct rather than indirect 
regulation of highly leveraged institutions such as hedge funds in the context of the work of the Financial Stability Forum. There has also been a broad related discussion among the $\mathrm{G} 7$ members on how to reform the IMF. In spite of the different nuances and differences, the $\mathrm{G} 7$ has been able to reach a significant and constructive consensus about the various elements of architecture reform, including PSI, as shown by the G7 Koln summit report and the Fukuoka summit report, as well as other G7 finance ministers reports and communiqués at the IMF-World Bank meetings.

The G7 dialogue has included issues such as the following: how to reform IMF facilities with Europeans more sympathetic to the Extended Fund Facility (EFF) and the United States wanting to provide a greater role to the Contingent Credit Line (CCL); how much emphasis to give in country programs to traditional macroeconomic policies relative to structural ones; how to reform the governance structure of the IMF (with Europeans pushing to turn the former Interim Committee into a stronger and more powerful executive body; the eventual compromise turned it into the International Monetary and Financial Committee [IMFC]); and how to reform the current country quotas (because, according to some criteria, the European countries are currently overrepresented and emerging market economies are underrepresented). ${ }^{21}$ Again, this dialogue has been constructive and led to the development of a consensus as represented by the G7 April $2000 \mathrm{Fi}$ nance Ministers Communiqué at the time of the IMF-World Bank annual meetings. At the annual IMF-World Bank meetings in Prague in September 2000, agreement was reached on how to operationalize the reform of IMF lending facilities and broader reform of the IMF.22

Developing countries believe that they should be better represented in the decisions that affect them. The issue of the representation of significant emerging market economies in international bodies has emerged not only in the context of the discussion about IMF quotas but also in the U.S. position, viewed with some concern by some European G7 countries, that the views of such emerging markets should be more broadly represented in global affairs. Europeans know that any such shift in power will come largely or entirely at their expense. The U.S. push to involve emerging market countries began with a proposal by President Clinton in November 1997, at the Vancouver Leaders Summit of the Asia-Pacific Cooperation forum. It took the form of support for the inclusion of important emerging market governments in the ensuing Group of Twenty-Two and Group of Thirty-Three (G22 and G33) process, support that led to three early reports in late 1998 on international architecture reform. These groups were followed by the creation of the Group of Twenty (G20) as a regular forum of

21. See IMF (2000c) for the report of the official "Cooper Commission" on how to reform the country quotas.

22. The details of this agreement are described later in the "Recent G7 Initiatives to Reform the International Monetary Fund" section. 
dialogue among advanced industrial economies and a group of systemically significant emerging markets. The transformation of the Interim Committee into the IMFC balanced some European concerns about the creation of new groups such as the G20.

\section{Coordination among Central Bankers and the Bank for International Settlements}

G10 central bankers and the BIS have also been involved in crisis management and resolution. A particularly significant role in crisis response and management has been played by the U.S. Federal Reserve given the lead role of the United States in international financial policies. The role of G10 central banks has been more prominent in the large systemic liquidity cases than in the smaller, nonsystemic countries' cases. In the former cases (Mexico, Thailand, Indonesia, Korea, Russia, Brazil), G10 central banks have been directly involved in the formulation of official policy: consultations on how to deal with systemic countries and on the size of official rescue packages and involvement in lining up second lines of defense financial support.

G7 finance ministries have been most directly in charge of the design of official G7 policy regarding the reform of the international financial architecture (the Koln and Fukuoka summit reports), but central banks have been widely consulted in this process.

G10 central banks' direct involvement in the formulation of official policy for PSI in crisis resolution has been more limited (relative to that of treasuries and finance ministries), although G10 central banks have run some seminars and activities in the debate on PSI. Their involvement in nonsystemic debt restructuring cases has also been more consultation than direct crisis management even if some central banks (the U.S. Federal Reserve and the regional New York Federal Reserve) play a larger role in such cases as well.

G10 central banks and the BIS play a larger role in addressing global systemic risk issues and in questions of international financial regulation (the Financial Stability Forum work). The Federal Reserve was deeply involved in the management of the LTCM crisis. The Basel Eurocurrency Committee (now the Committee on Global Financial Stability [CGFS]) has been involved in discussing and managing the response and formulation of policies to address episodes of global financial turmoil, global liquidity shocks, and systemic financial crises.

G10 central banks have also been deeply involved in the work of the Financial Stability Forum and its formulation of recommendations on highly leveraged institutions, short-term capital flows, offshore financial centers, implementation of codes and standards, and reform of deposit insurance.

Also, the formulation of monetary policy by G10 central banks has been affected by episodes of systemic crises. The reductions of interest rates by 
the Federal Reserve and many other central banks in the fall of 1998 (following the Russian default, the LTCM crisis, the seizure of global liquidity, and the spillover of financial turmoil from emerging markets to U.S. and other G7 capital markets) were not coordinated but were successful in stemming the risk of a global financial meltdown.

Also, the work on the reform of the Basel Accord (the BIS capital standards) has seen a central role for the central banks and other institutions that supervise and regulate the banking and financial system.

\section{Paris Club}

The Paris Club (PC) is a major forum for crisis management and resolution, because it is in charge (in consultation with the IMF) of the rescheduling of official bilateral credits to emerging markets. The PC has become a lightning rod for complaints of the private sector against the official policy for PSI in crisis resolution. Complaints emerged from recent policy debates and private financial-sector views on official PSI policy in general and bonded debt restructuring in Pakistan, Ukraine, Russia, Ecuador, and Nigeria specifically. The club has been accused of a number of ills: being a secretive organization, arbitrary and unfair in its decisions; forcing the private sector to be the residual claimant (deciding first how much the official creditors are paid in cash when there are external financing gaps and letting the residual be paid to private creditors); expecting private debt reduction when it does not provide any itself; lacking transparency, predictability, and openness; being unwilling to engage the private sector in negotiations and dialogue; being politically biased in its decisions; and imposing comparability (the restructuring of private claims on terms comparable to the restructuring of official claims) while not accepting reverse comparability (the restructuring of official claims on terms comparable to those of private claims in cases - like that of Russia - when private claims are restructured before PC ones).

Many of these critiques suggest a significant misunderstanding in the financial community of the role and functions of the PC.

The first misconception about the $\mathrm{PC}$ is the belief that its claims are senior to those of the private sector. Although official bilateral claims are perceived to have legal seniority over private ones, the reality of international finance is that PC claims are always effectively junior to private ones. When a country experiences debt-servicing difficulties, the first payments that are suspended are those to PC creditors. Debtors know that going into arrears to PC creditors has little consequence (because such claims are eventually rescheduled), whereas nonpayment to private creditors has consequences (formal default, acceleration, litigation risk, etc.). Thus, debtors are most eager to stop paying official bilateral creditors well before they stop paying private creditors. Indeed, strategic nonpayment to the PC has long been used by debtors as a way to continue paying in full and on time to private 
creditors. The accumulation of arrears to PC creditors is a systematic and endemic phenomenon that has allowed continued payments to private claims. For example, Nigeria accumulated over $\$ 23$ billion of arrears to the $\mathrm{PC}$ and has so far paid in full its private debts. This is a distorted system of incentives: no private creditors would be willing to provide credits to a sovereign at the terms, risk features, and spreads provided by official bilateral creditors. Indeed, the fact that countries were still able to have market access in spite of rising PC arrears (as in the case of Ecuador's issuance of Eurobonds in the mid-1990s) implied that investors believed that the financing burden would be shifted to the official creditors and they would not be "bailed in." However, recent applications of the PSI framework (discussed below) have changed this perception: investors do now realize that countries with significant PC arrears are more likely to be involved in PSI, when private claims are material.

Second, PC claims not only are the first to go into arrears, but they are immune from litigation risk; they are not subject to rollover risk because they effectively have a rollover option given to the debtor, in that the latter can always stop paying with little consequence; and they are not subject to liquidity risk driven by any panic from creditors withdrawing lines of credit. Also, such claims are restructured at terms that are often quite generous and at interest rates that do not truly reflect repayment risk. Note that if the market had to provide similar claims not subject to rollover, liquidity, and litigation risk, the pricing of such debt (in terms of spread over risk-free assets) would be most expensive. Consequently, the treatment of PC claims is more beneficial in most dimensions for the debtor than that of private claims.

Third, the PC does not systematically provide debt reduction apart from cases in which the country qualifies for debt reduction, such as qualification under the Highly Indebted Poor Countries (HIPC) initiative or other criteria. However, the terms of $\mathrm{PC}$ rescheduling are generous and imply some significant effective reduction in the net present value (NPV) of such claims. In fact, the PC fiction of rolling over claims at the contractual original low interest rate and discounting the present value of restructured claims with a discount rate equal to this rollover rate allows the accounting fiction of maintaining NPV neutrality. The use of a more economically appropriate discount rate reflective of the actual expected repayment probability would imply some significant NPV reduction. Finding the appropriate discount rate for PC claims is not easy. It is likely to be smaller than market rates but much higher than the officially used rate. Nevertheless, the terms of PC claims and their restructuring (systematic arrears; no rollover, liquidity, and litigation risk; generous restructurings with long grace periods and low interest rates; and eventual debt writedowns for some qualifying debtors) suggest that, in most cases, PC claims are effectively reduced rather than just restructured even though not formally subject to face-value reduction. 
Arguments that PC restructurings are unfair to private creditors when, as in the case of Ecuador, the private sector is asked to provide for debt reduction while the official sector is not, miss the point: $\mathrm{PC}$ restructuring is usually not NPV-neutral. Thus, PC restructuring can be "comparable" to private claims debt reduction even when formal face-value reduction is not immediately provided by $\mathrm{PC}$ creditors.

Fourth, the rules followed by the club are quite clear and the criteria, amounts, and terms of restructurings quite forecastable, given the track record and procedures of the PC (normal terms for middle-income countries, Houston terms for poor ones, HIPC terms for those who qualify for HIPC, etc.). Thus, the private sector is normally able to infer how much finance will be provided by the PC creditors. The current process is not much different from that in the 1980s by which PC restructurings were followed by London Club restructurings on "comparable" terms. (The London Club represents private banking creditors in the same way that the PC represents government creditors.) The main difference is that now bonded debt may also be subject to comparability because it is no longer "de minimis"-a consequence of the rising importance of securities markets in international capital flows that were once dominated by bank loans.

Fifth, the PC could do better in terms of providing more information and transparency about its activities. There are limits to what can be done, because the $\mathrm{PC}$ is not a structured formal organization but rather an ad hoc group of rotating creditors. In this sense, there is not an official PC view, spokesperson, or common view; any external view would have to be cleared by all relevant creditors. However, the PC has recently made some progress on this front by committing to the creation of a website that will provide information to markets and investors about its activities, rules and procedures.

Sixth, the idea that "reverse comparability" would be used in deciding how to fill a financing gap would create many problems. Some clear burdenslicing rules such as a proportionality principle (whenever there are external financing gaps to make cash payments on debt servicing due and to restructure private and official claims according to the proportion of private and public claims coming to maturity) would provide a simpler, more predictable, and, some would say, fairer distribution of the burden than a formal negotiating process. Moreover, the nature, motivation, and terms of the official bilateral claims are very different from those of the private claims; thus, attempts to negotiate a "fair" distribution of the burden are burdensome and add to uncertainty rather than reducing it. In addition, the current structure of the distribution of the financing burden (country adjustment first, senior status for new International Financial Institution money, more junior status for PC claims with clear and established rules for their restructurings, and residual financing by the private sector) provides a clear and mostly predictable system of adjustment and financing. It 
is not clear that a system in which the financing burden on the private sector is negotiated would improve on this system.

Seventh, although private-sector participants concentrate on the contribution of the PC creditors, the effective contribution of the official sector to PSI also includes the new money provided by the multilateral creditors. This contribution is often significant and may even be larger than that of bilateral creditors. Conceptually, the larger the combined support of official creditors (both bilateral and multilateral), the smaller the amount of private claims that are subject to PSI. Indeed, often the private-sector response to requests for PSI has been to ask the official creditors as a whole to fill in the entire financing gaps, to avoid nonpayment on private claims so as to shift the full adjustment burden onto the official sector.

Eighth, some confusion derives from the fact that the PC does "flow restructurings" while the private sector does "stock restructuring." The origin of this distinction goes back to the 1980s. The PC would restructure all the claims (including arrears) that came due during the consolidation period; thus, only current payment flows are restructured, rather than the total stock of outstanding debt to official creditors. This also means that repeated flow restructurings of PC claims are necessary, because the stock of debt is not dealt with once and for all, but only the consolidation-period flow payments. The London Club instead would take a stock approach, given the nature of the claims rescheduled (i.e., syndicated bank loans), and restructure the entire stock of claims that were due in the consolidation period, both interest and full principal. Once the doctrine of PSI was applied to bonds starting in 1999, it was logical to take a stock approach for the bonded debt. Although restructuring only payments due in the consolidation period could be technically feasible, dealing with the full stock makes more sense because bond restructurings require bond exchanges of the full stock of debt. It would be extremely cumbersome and inefficient to have only flow restructurings of bonded debt and to do bond exchanges over and over again every few years. Thus comes the rationale of dealing with the stock of bonded debt once and for all and restructuring it according to terms that ensure medium- to long-term viability of the debtor.

Ninth, formal negotiations of the private sector with the PC to discuss the "slicing of the pie" are not likely to be productive, for several reasons. First, PC rules for restructuring versus upfront cash payments are clear and known for a long time. Second, negotiations may lead to endless delays beneficial to none. Third, the current system is effectively close to the proportionality distribution of the debt burden described above. Also, once the up-front cash payment distribution has been figured out, there is little to negotiate because the constraint of medium-term debt sustainability and standard PC rules for the terms of the restructuring of the remaining liabilities determine clear parameters of what is comparable and what is sustainable.

Finally, although the original PC claims against a sovereign may be fi- 
nancing projects that are not motivated on strict commercial terms, this does not mean that all PC loans are strictly "political." If there is a political element in such loans, the effectively subsidized terms of the loans (that is, interest rates that are submarket, adjusted for repayment risk) also price that subsidy transfer. Also, some of the financed projects are either formally or informally of a tied-aid nature and provide benefits to private-sector firms of the creditor country. Thus, the private sector often significantly benefits from such "politically" motivated loans.

\section{Other Government Agencies and Heads of State}

Other government agencies, such as national security agencies, ministries of foreign affairs, and defense ministries, as well as heads of government, are also involved in crisis management in important countries even if finance and treasury ministries have had a central role. Quite naturally, geopolitical, strategic, and military considerations play some role in deciding the response to crises. A naive view would argue that the introduction of noneconomic considerations in crisis response represents an interference with sound economic judgment. However, decisions about international financial policy are inherently political in the positive political-economy sense of the word. Countries are "of systemic importance" not only because their size implies systemic contagion effects to other economies in the region or around the world; they are also systemic for geostrategic reasons. For example, Indonesia is the largest Muslim country in the world; its stability has economic and strategic implications for the entire Asian region. Russia is also systemically important, for both the United States and Europe, in part because of geostrategic reasons even though its GDP is smaller than that of the Netherlands. To consider these political factors need not imply compromising sound economic judgment on whether and how much support should be given. It means instead that the policy process considers the political economy of stabilization and reform: how much a country can adjust given its political constraints, and the strategic implication of providing or not providing financial support. ${ }^{23}$ The concern that consideration of extraeconomic issues may lead to moral hazard (expectations of bailout of systemically important countries) has a valid basis. Rarely, however, do such considerations dominate more narrow economic criteria for supporting adjustment in a crisis country. In the dialogue between finance ministries and agencies for national security, the former usually play the role of guardians of fiscal and monetary orthodoxy and stress the importance of

23. Some critics of the IMF as not being "independent" of its leading members (De Gregorio et al. 1999) miss the point. In a positive sense, the IMF is a "political" institution that is accountable to its shareholders while at the same time maintaining its standards, following its mandate, and rigorously applying its articles of agreement. As in any other efficient principalagent relation and corporate governance issue, the appropriate balance between goals and objectives of major shareholders ( $\mathrm{G} 7$ and other industrial countries) and minority shareholders (emerging market economies) has to be found. However, independence, by itself, has little meaning. 
sound politically unbiased decisions on whom and by how much to support financially. The latter are, obviously, more concerned about the strategic effects of letting a systemically important country go. Sometimes the finance ministries explain to the others that there may be no way the West can help a crisis victim that isn't willing or able to help itself, no matter how politically sensitive the country is.

National security agencies and foreign affairs ministries are also quite involved in consultations with finance ministries on the proper response to crises in non-systemically important countries. Some of them (Pakistan, Ukraine, Ecuador, Romania, Nigeria) have political importance that goes beyond their economic size. Generally, finance ministries are more "hawkish" (less willing to provide support to poorly managed economies where there is a poor track record of commitment to stabilization and reform), whereas other agencies, ministries, and departments are generally more "dovish."

Heads of state get involved in crisis management in large systemic cases (Mexico, Thailand, Indonesia, Korea, Russia, and Brazil), during episodes of severe global financial turmoil (as in the fall of 1998) and as a part of the G7 summitry. The speech at the Council on Foreign Relations by U.S. president Clinton in the fall of 1998 showed - at the highest level — the concern about the risks of a global financial meltdown and engagement in trying to design policy responses to such a risk. Progress on architecture reform has been achieved in preparation for various $\mathrm{G} 7$ heads-of-state summits (Halifax, Kohln, Okinawa). Even the formation of the G20 was a partial response to heads of state interest in getting involved in a broad dialogue on global issues, although the eventual G20 group was centered around finance ministries rather than heads of state.

\section{The Role of the G3}

The G7 club is already sufficiently exclusive to expose it to charges of elitism. However, even this exclusive club of richest countries can be effectively reduced to the G3: the United States, the European Union (EU), and Japan. Furthermore, it is commonly believed that the United States has disproportionate power in the deliberations of the $\mathrm{G} 7$ and IMF. The complaint that the global system is essentially run by the Group of One (G1) is well represented by the following quotation.

[C]ertain national governments - and the United States in particularexercise a disproportionate influence over the decisions taken by the Fund. In this view, the Fund too often pursues policies that serve the interests of Wall Street and the U.S. State Department rather than the world as a whole. ... [T] he IMF is too responsive to the agendas of national governments (the governments of its principal shareholders in particular). . . . The U.S. government's prominence in international financial markets and large voting share in the Board enable it to exercise a disproportionate influence over decision-making in the Fund. (De Gregorio et al. 1999, 1-4) 
These authors propose that the IMF be given independence, in the manner of an independent central bank, in order to insulate it against pressure from the United States and other large shareholders.

It is unquestionably true that the United States has an influence on global governance that is more than proportionate to its economic size, let alone to its population. Three of many instances in which it is widely believed that the U.S. Treasury wielded heavy influence in the IMF include February 1995, when the United States persuaded Managing Director Michel Camdessus to ram through emergency financial support for its neighbor, Mexico, despite opposition from some other major shareholders; December 1997, when a U.S. assistant secretary of the treasury went to Seoul to tell the Korean government what would be the conditions of its IMF program; and several instances during the 1990s when the IMF was arm-twisted to make a lenient interpretation of Russian compliance with the terms of past programs, to prevent the world's number two nuclear power from going into default. This record has been accompanied by steady grumbling, and worse, on the part of other industrialized countries, especially in Europe, as well as developing countries.

If one wished to pass judgment on this state of affairs, much would depend on how well one thought the United States has used its power-intelligently or incompetently, benevolently or selfishly. It is the view of the authors that the power was used well in the emerging market crises of the 1990s, when one considers the policy choices that had to be made and avoids comparing the actual outcomes with unattainable alternatives. Consider the example of the policy toward Russia, much maligned on account of corruption in that country and the ultimate failure of the IMF program in August 1998. There simply did not exist an option that read "first end corruption and establish rule of law; then support enlightened economic reform." The IMF has to work with the government in place, especially if it is democratically elected. It is not the United States alone, but everyone, that has a high stake in a stable and happy Russia. On the one hand, not to have supported Yeltsin when the best reformers in a century were in the Russian government would have been to say that the West was never prepared to help Russia. This is true even when one knows full well Russia's corruption and other problems. On the other hand, to have continued supporting Yeltsin in $\mathrm{Au}-$ gust 1998 would have been reliably to throw good money after bad. This is true even when one knows full well that the alternative was default and devaluation. The combination of support when there was a chance that reform would work, and pulling the plug in 1998 when the moral hazard had become severe, sent the right combination of signals. Either a policy of never helping or a policy of always helping would have sent much worse signals.

The considerable power of the U.S. Treasury may not always be wielded as wisely as we feel that it was in the crises of 1995-2000. There are broader issues of international political economy at stake, however, that would be 
relevant even aside from the quality of personnel in any future U.S. administration.

The most important argument in favor of the U.S. role is the classic argument of international relations theory that the world needs a leader to organize the delivery of "public goods" such as international monetary stability. In a world of many small or medium-sized powers, the free-rider problem would prevent effective collective action: it does not pay for any one country to organize or sustain multilateral cooperation. Charles Kindleberger has argued that Great Britain was the hegemon before World War I - the guarantor of free trade, the gold standard, and the Pax Brittanica. In this view, the fundamental reason for the economic, political, and military horrors of 1919-44 was that Britain had lost the capacity to act as hegemon and the United States had not yet gained the will to play the role. The fundamental reason for the relative harmony and prosperity of the postwar period is that the United States did play that role, in part through the IMF and other multilateral institutions, and has continued to do so in the management of recent crises in emerging markets.

Although the United States has played a leadership role in international financial affairs and the management of recent crises, one should not overstate the hegemonic role of the United States. The G7 process, at the level of both heads of state and finance ministers, works on a consensus basis. The United States may have provided leadership in crisis management, in proposals for the reform of the international financial architecture, for PSI in crisis resolution, and in reform of international financial institutions (IFIs: IMF and multilateral development banks [MDBs]), but the process that has led to the implementation of these reforms has operated through a broader consensus. For example, on architecture reform, PSI reform, and IFI reform, initial U.S. and other countries' proposals lead to an intra-G7 dialogue and eventually to a G7 consensus on these policies and reforms. Next, other emerging market countries were involved in the process (in a number of forums: G22, G33, G20, FSF, etc.) so as to reach a global consensus and decisions to approve the reforms were made within the IMF executive board, where all member countries are directly or indirectly represented.

A valid question is whether the United States is up to the role of global leadership. It showed that capacity after the end of World War II; but can it now, fifty years later? In one way, the United States is well suited for hegemony: its domestic economic and political system sets a good example for the rest of the world, a model that is attractive and overall beneficial. In another way it is ill suited to be global leader: many in the public, and especially in Congress, have lost interest in the role. We consider this latter problem.

\section{Lack of Domestic U.S. Support for Internationalism}

Many Americans are now reluctant to pay the price for global leadership, even when the price is small. There is a lack of interest in internationalism. 
The United States has won the Cold War, as well as the international economic competition, but it may not be sufficiently interested in collecting its winnings to put down the small deposit required for the job of hegemon.

Examples come readily to mind. As recently as thirty years ago, it would have seemed a great "deal" for the United States to be able to exercise influence in the IMF that is more than proportionate to the size of its quota; in 1998 Congress was very reluctant to approve the U.S. share of the quota increases. Thirty years ago the United States criticized the Russians for neglecting to pay their UN dues; in the 1990s, the United States was the nation chronically in arrears. Ever since 1974 the U.S. Congress has given presidents authority to negotiate trade agreements on a fast-track basis, but Congress continued to deny this authority to President Clinton. The United States seems unconcerned that it is almost completely isolated in its position in international negotiations over such issues as the land mines treaty, International Criminal Court, Kyoto Protocol, Comprehensive Test Ban Treaty, and the antiballistic missile treaty.

Ten years ago, much of this reluctance on the part of the American Congress and public to play an active role in the world had already become evident. However, in the 1980s the fear was that the U.S. economy was in decline, particularly compared to Japan and other East Asian countries. It was said that the United States could no longer afford the cost of leadership as it could have when it had the world's strongest economy. Even at that time, there were serious flaws in this argument. The decline in U.S. economic performance was only relative to others, the natural result of gradual economic catch-up in GDP per capita on the part of many countries. If in the immediate postwar period the United States could afford the vast sums involved in the Marshall Plan, it is hard to see why it could not afford in the 1980s to remain the leading aid-giver (for example) at a time when its income was considerably higher than in the 1950s.

However, it is perhaps more surprising that the reluctance of the U.S. Congress to exercise global leadership continued, even deepened, in the 1990s - surprising because U.S. economic performance was so spectacular, whether measured by the length of the expansion (ten years, an all-time record), the average growth rate (4 percent in the late 1990s), the swing from budget deficit to surplus (records in both cases), or the low rates of unemployment and inflation (to the levels of the 1950s).

The lack of domestic support for internationalism is a serious minus for U.S. leadership. Poll results show a higher level of support among the general public than one might think. A poll by the Chicago Council on Foreign Relations found that 61 percent of the public (and 96 percent of leaders) support an active U.S. role in world and that 54 percent think globalization has been good for America. A poll by the Program on International Policy Attitudes found that 61 percent of Americans favored globalization, almost 80 percent of respondents supported more international cooperation, and 
a plurality even supported a stronger IMF. However, evidently few people feel strongly about foreign affairs issues, except when they think their economic interests are specifically at stake or when they have relevant ethnic ties. The poll results do not translate into support in Congress.

An amateur political scientist can think of five interrelated reasons for a decline in political support for international initiatives:

1. The end of the Cold War. When the United States was in a global contest with the Soviet Union, many in Congress were willing to support initiatives that they were told would contribute. This ended with the breakup of the Soviet Union.

2. Reversion to pre-1941 isolationism. During most of its history, the United States avoided "entangling alliances." It was a reluctant entrant into the two world wars. The period of strong support for international engagement was a deviation from the normal, attributable to the experience of those wars and to a conviction that the Europeans could evidently not be trusted to manage their own affairs.

3. The passing of the World War II generation. By now, those who had the experience of living through and fighting the war have retired from the ranks of senators and presidential candidates. Perhaps those who have taken their place have less appreciation for the long-term dangers of staying out of international affairs. One is tempted to make an analogy with stock market crashes and with the theory that tolerance for risk in the stock market has been rising since the generation of investors who witnessed the crash of 1929 passed from the scene.

4. Lack of trust in elites. Until recently, most voters would accept the word of experts and leaders that fast-track negotiating authority or International Development Association replenishment was necessary, even if they did not understand them. In the wake of Vietnam, Watergate, and so on people no longer trust elites on any issue. Thus they are unwilling to take their word for it in the area of international finance.

5. A general feeling that money is wasted by international bureaucracies. Polls show that voters think the United States spends far more on foreign aid than it actually does. Apparently they would be willing to allocate more than we currently do if they thought the money would be spent efficiently. ${ }^{24}$

\section{The U.S. Congress}

The relevance of America's constitutional separation of powers is not a mere abstraction. The government has been substantively divided in most recent years. For example, the executive and legislative branches have been in the hands of different parties since January 1995. In 1998, at the height of

24. Most measures relevant for emerging market crises are not foreign aid. Even the quota contributions to the International Monetary Fund are not budgetary costs but rather asset exchanges. 
the emerging market crises, Congress initiated proceedings to impeach the president.

Throughout the postwar period, the American executive has generally been committed to international engagement. This was as true of President Clinton as of his predecessors. In the economic sphere, the biggest international accomplishments in the first Clinton Administration were probably the passage of the WTO and North American Free Trade Agreement (NAFTA) legislation and the Mexican rescue program, and in the second administration, the management of the East Asia crisis.

Congress has been much less supportive. Congress showed its resistance to the Clinton Administration's activist approach to emerging market crises in a number of ways. Two of the most important were its opposition to the use of government funds in the Mexican peso crisis and its initial opposition to an increase in resources for the IMF in 1997-98.

In January 1995, the first attempt by the administration to put together a Mexican support package would have required congressional approval. Notwithstanding that the senate majority leader and the speaker of the house, the newly installed Newt Gingrich, agreed in a White House meeting to support the request, the rank and file in Congress rebelled. By the end of February, the administration was forced to give up on Congress and use the Treasury's exchange stabilization fund (ESF) instead. Use of the ESF is at the discretion of the secretary of the treasury (Henning 1999). The Mexico policy worked well: financial confidence quickly stabilized, the Mexican economy (after an admittedly severe recession) recovered in the second year, and the U.S. Treasury loan was repaid ahead of schedule, at a profitable interest rate. (We consider in the next section the argument that this policy, by posing a moral hazard of "bailout," sowed the seeds for the East Asia crisis three years later.) In any case, many in Congress showed anger that the administration had gone ahead. The D'Amato amendment retaliated by putting severe restrictions on the Treasury's use of the ESF.

When the Thai crisis broke in July 1997, the United States was not one of the countries that contributed bilateral funds to the rescue package. In retrospect this was probably a mistake, in light of the ensuing contagion to much of the world. Certainly the Thais were offended that the United States did not contribute, whereas American funds were made available as part of the "second line of defense" in the Korean and Indonesian rescue packages a few months later. However, a key difference was that the D'Amato amendment expired between the dates of the Thai rescue and the subsequent crises, freeing up the ESF. Thus, if it was indeed a mistake for the United States not to participate, at a time when the Thais were prepared to make needed policy reforms and the systemic crisis arguably might have been nipped in the bud, the mistake could be attributed to Congress.

Many in Congress continued to be hostile to administration efforts, whether out of genuine concerns regarding moral hazard or with the motive 
of seizing an opportunity to make political hay. Congress refused to approve the administration's request that the United States contribute its $\$ 18$ billion share of an increase in IMF resources - which was to consist of an increase in members' capital quotas and the establishment of the New Arrangements to Borrow. Sentiment in Congress did not begin to change until the Russian default in July 1998 ushered in round two of the crisis. Many market observers were caught by surprise, having expected the G7 and IMF to continue to bail Moscow out under the logic that it was "too important to fail."

For better or worse, some market observers concluded from the Russian default that the IMF might have run out of resources. (Others drew the lesson that unilateral sovereign defaults on bonds had suddenly become more respectable. The most important of the three possible lessons that could have been drawn, that the IMF and G7 were after all serious about conditionality, was the slowest to win acceptance.) In any case, investors everywhere fled from risk and loaded up on liquidity. An unprecedented contagion spread to Brazil and throughout the western hemisphere. Sovereign spreads on emerging market debt rose to 15 percentage points above treasuries in September. The excess demand for liquidity affected U.S. financial markets, most notably in the form of the near collapse of LTCM. Spreads on corporate bonds rose. News magazines put aside their New Economy or Overheating Economy cover stories and instead began to ask if a global economic meltdown was imminent.

President Clinton's speech on the subject of the crisis in September 1998, before the Council on Foreign Relations in New York, implicitly responded to fears that he and other G7 leaders had been too preoccupied with domestic matters to pay attention. He made evident that there was indeed "someone minding the store" (Waldman 2000, 230-36). There, and at the IMF annual meetings the following month, the White House laid out a series of initiatives to address the current crisis and as well to reform the financial architecture so as to avoid future repeats. (The signal of a change in global monetary policy was discussed in the first section of the chapter.) The president also, for the first time, used the word "irresponsible," in describing congressional foot-dragging on IMF funding. Some congressmen began to worry that if a global recession were really to take place, they would be blamed.

Finally in October Congress responded by passing the funding package for the IMF, opening the way for about $\$ 90$ billion of usable resources to be provided by all IMF members. The financial refueling of the IMF, in conjunction with the easing of monetary policy and various G7 initiatives, probably contributed substantially to the subsequent weathering of the stresses on Brazil and the easing of the crisis worldwide.

There is one sense in which the low and variable level of congressional support for American international engagement generally, or for bailouts in 
particular, is useful, however. That is the doctrine of constructive ambiguity in bailout policy. ${ }^{25}$ Consider the analogy of the domestic lender of last resort. The Federal Reserve does not admit to having a policy that some banks are automatically "too big to fail." To reduce moral hazard, it seeks to maintain ambiguity as to whom it would bail out. In the case of the largest banks, this coyness is not credible. They are too important to the payments system and thus to the entire economy to be allowed to fail. This is a moral hazard problem with no good solution. At the international level, American claims that in the future the G7 will not necessarily bail out troubled debtors are more credible. In the event of a repeat crisis, it may be that a future executive will seek once again to put together a rescue package for suitably deserving and systemically important countries. ${ }^{26}$ However, nobody can be confident that Congress will go along. Thus the constructive ambiguity is credible.

\section{Moral Hazard and Private-Sector Involvement in Crisis Resolution ${ }^{27}$}

The problem of moral hazard and attempts to address it by involving private investors in a rescue package are relevant to any attempt at crisis management.

\section{Introduction}

The issue of the appropriate ways to involve the private sector in crisis resolution has been one of the most hotly debated and contested policy questions to emerge since the onset of currency and financial crises in the $1990 \mathrm{~s} .^{28}$ It is one of the core issues in the current debate on the reform of the international financial architecture.

Even the definition of the problem is controversial. The issue under consideration has been defined by different authors as the "bail-in" issue (as opposed to "bailout"), the "burden-sharing" issue, the "private-sector in-

25. See the longer discussion in the section "International Lender of Last Resort."

26. This is equally true whether the president is a Democrat or Republican. It is only after they leave office that policymakers such as former Secretary of State George Schultz decide that the IMF should be abolished (Schultz, Simon, and Wriston 1999). The first Reagan Administration made full use of the IMF and U.S. funds to bail out countries in Latin America and elsewhere that had more profligate fiscal and monetary policies, larger state sectors, and less liberalized economies than the emerging market countries that the IMF rescued in 1995-98.

27. See Roubini (2000) for a more detailed discussion of the bail-in, burden sharing, and PSI debate and issues.

28. Recent official-sector views and policy on PSI can be found in Rubin (1998), Köhler (2000), Fischer (2000), Summers (2000), Geithner (2000), Group of Seven (1999, 2000) and IMF (1999). Private-sector views include IIF (1999a,b), Corrigan (2000), Bucheit (2000), Cline (2000), Dallara (1999), Kahn (2000), and Independent Task Force (1999). Some academic views include Roubini (2000), Eichengreen (1999b, 2000), Eichengreen and Portes (1995), Eichengreen and Ruhel (2000), Dooley (2000a), Portes (2000), Friedman (2000), Haldane (1999), Kenen (2001) and Rogoff (1999). See Cline (1984) for an analysis of crisis resolution during the 1980 s debt crisis. 
volvement" question, and, most recently, the "constructive engagement" of the private sector question. ${ }^{29}$ The definitional semantics are themselves loaded with the views of different actors (creditors, debtors, and the official sector) of what such involvement should be. The issue of PSI remains highly contentious and complex.

In a sense, PSI is not new at all. The evolving strategy to deal with the international debt crisis of the 1980s already implied a significant, and somewhat coercive, involvement of the private sector in crisis resolution: sovereigns stopped payments on their syndicated loans to international banks; significant debt servicing difficulties emerged; bank loans were first rescheduled, then restructured and rolled over; new money was at times put on the table; and eventually debt reduction came via the Brady plan workouts. ${ }^{30}$

What was new in the 1990s was not PSI but the nature of the debt instruments, creditors, and debtors. As for instruments, bonded debt, short-term interbank loans, other structured debt securities, and derivative instruments have increasingly supplanted syndicated medium-long-term bank loans. As regards creditors, commercial banks have been increasingly supplanted by a whole host of other creditors, such as small and large bondholders, investment banks, hedge funds, and real money investors (such as mutual funds and pension funds). Among debtors, although sovereigns are still important, private-sector debtors in emerging markets (such as financial institutions and corporations) are increasing their share of cross-border borrowing.

Whereas in the 1980s the challenge was to restructure and reschedule the loans of a limited set of commercial banks, the challenge in the 1990s became one of rescheduling and restructuring bonded instruments (as well as cross-border short-term interbank loans). Bond rescheduling was not an issue in the former period because bonded debt was mostly "de minimis" compared to bank loans. Initial attempts by the public sector to include

29. A first term used to discuss this issue was "bail-in" as a way to connote the need to avoid systematic "bailouts" of private-sector creditors during crises. This term was deemed a bit too coercive by some, who preferred instead "burden sharing." However, even the latter phrase was contested as suggesting equity considerations rather than the need to fill a financing gap; the term also had coercive connotations that appear at odds with the goal of constructively involving the private sector in crisis prevention and resolution. Thus, the increasing use by the official sector of the term "private sector involvement in crisis resolution" (often referred to as PSI policy) with the adjective "appropriate" often added in front of PSI to stress the view that such involvement should be as voluntary, constructive, and cooperative as possible. Most recently, the new IMF Managing Director Köhler (as well as the outgoing Deputy Managing Director, Stanley Fischer) has suggested a new phrase, "constructive engagement," that emphasizes the need for voluntary and market-based solutions, as opposed to forced or coercive approaches, to PSI. Unfortunately, this series of increasingly less explicit terms has made it harder and harder for the nonspecialist to know what is meant.

30. A detailed discussion of PSI in the $1980 \mathrm{~s}$, from payment suspensions on syndicated loans in the early 1980s to the implementation of the Brady plan in the late 1980s and 1990s, is beyond the scope of this paper. Cline (1995) presents a comprehensive discussion of this issue. 
bonded debt into PSI were received with skepticism by the private sector as well as the debtors. It was argued that although in the 1980s it was relatively easy to convince a small set of homogenous creditors subject to regulation and pliant to forbearance (commercial banks) to reschedule a set of homogenous instruments (syndicated bank loans), it would have been impossible to restructure some instruments that were more common in the 1990s. This applies particularly to bonds that did not have collective action clauses, that were heterogeneous in their legal and economic features (Eurobonds, Brady bonds, and other bonded securities) and that were held by thousands of creditors who were marking to market, not heavily regulated, and neither willing to engage nor expert in bonded debt instrument restructuring. The collective action problem of coordinating the actions of such a disparate and large group of creditors without creditor committees or majority and sharing clauses was deemed to make it all but impossible to restructure bonds. Also, it was argued that the short-term nature of the interbank loans would make them hard to restructure: creditors would stop rolling them over and would close their positions before the debtors could even start thinking about a possible partially involuntary rollover. The reality of PSI in the 1990s turned out to be quite different from these pessimistic assessments.

For one thing, the collective action problems were also quite serious in the 1980s: there were hundreds of commercial banks with different exposures and interests; the free-rider or holdout problem was as serious then as now; and the debt instruments were quite heterogenous, because hundreds of very different syndicated loans had to be repackaged and restructured. ${ }^{31}$ Moreover, as the recent restructuring of the bonded debt of Pakistan, Ukraine, Russia, and Ecuador suggests, restructuring is feasible even in the absence of ex ante collective action clauses (CACs). Also, with the emergence of short-term interbank loans in the 1990s, in part a reaction to the bail-in of longer-term bank loans in the 1980s, a bail-in of such instruments to prevent liquidity-driven runs became a feature of the strategy. In different ways and with different degrees of coercion or voluntarism, the restructuring or monitored rollover of cross-border interbank loans in Korea, Brazil, Russia, Indonesia, and Turkey became part of the PSI policy of the 1990s.

Even the rationales for PSI have been contested and hotly debated. The official G7 doctrine on PSI stresses the following rationales. First, a balance of payments crisis creates an external financing gap. Even after the debtor makes domestic adjustments to policy and reduces domestic absorption as part of its policy adjustment process, a financing gap may remain because the amount of capital outflows and debt that has to be serviced exceeds the foreign reserve resources of the country avail-

31. Collective action problems were partly solved by having creditor committees where some financial institutions took a leadership role and prodded creditors to play ball with carrots and stick. The term "Rhodes Rolodex" has been used to characterize the central role played by Citicorp's Bill Rhodes in providing such a coordinating and leadership role. Interestingly, he played a similar role in some of the 1990s' restructuring episodes, namely in the case of Korea. 
able for external debt service. Second, involvement of official creditors may contribute to filling this external financing gap but cannot fill it altogether. Even generous PC restructurings of official bilateral debt and normal access by multilateral creditors to financial support from the IMF, the World Bank, and other MDBs still leave a financing gap. In other words, official money, unless it is exceptionally large (a hotly contested issue) cannot in most cases fill in the debtor's entire financing gap. Third, exceptional financing is not only infeasible given political, financial, and other constraints to large-scale official support, but also undesirable, apart from a few special cases. It is undesirable because expectations of official-sector bailout of creditors would lead to severe moral hazard distortions of cross-border borrowing and lending. ${ }^{32}$ Thus, financing gaps, the limited availability of official money, and moral hazard considerations are the basis of the need for "appropriate" PSI in crisis resolution. ${ }^{33}$

32. Throughout this section we use the term "bailout" interchangeably with "large official support." However, the term "bailout" has specific positive and normative connotations. When large-scale official finance is provided to a debtor country, this is not technically a bailout if the funds are eventually repaid to the IMF and official creditors. Indeed, in the recent episodes of large-scale support IMF loans have been repaid or have been serviced according to the terms of the lending. Some argue that these official loans have some subsidy component, but this alleged subsidization is far from a "bailout." One could argue that this official lending is a bailout in that it bails out international creditors of the sovereign or its private firms. However, even in this case the term "bailout" may be inappropriate: as long as the debtors (sovereign or private firms such as banks) are solvent, the creditors would be eventually repaid in full, and the IMF support only changes the timing of their receipts. Preventing the postponement of debt payment servicing that would have occurred if official funds were not available is of value to international creditors (because effective restructuring/ rollover/restretching of payments may have a net present value cost to them), but it is not, again, a full bailout. In cases in which the debtor is not solvent and a debt write-down would occur in the absence of official support, policies of PSI may effectively bail in creditors and provide burden sharing. Although the term "bailout" may thus be imprecise, in the following discussion we will use it in the loose form that has been used in the debate on bailouts versus bail-ins.

Note also that the degree of coercion in PSI will vary a lot depending on the specific cases. At one extreme are cases of "soft" PSI, where international investors commit to maintain exposure (as international banks in the cases of Brazil and Turkey) or when debt restructuring occurs on voluntary and market terms (as in the megaswap in Argentina in 2001). More coercive forms of PSI are the case of Korea where international banks agreed to turn short-term lines to Korean banks into medium-term government guaranteed claims under the effective threat of a Korean default. Similarly, the restructuring of the sovereign bonded debt of Ukraine and Pakistan, although not implying a reduction in the principal value of the claims, occurred at below market interest rates and thus implied some NPV reduction. At the other extreme are cases in which the country has effectively defaulted - by suspending payments on its domestic or foreign liabilities and the restructuring implies a reduction in the principal value of the claims (Russia, Ecuador).

33. Other goals of PSI have been mentioned from time to time. For example, the "unfairness" of bailing out private investors and having the official creditor sector fill in the full financing gap is behind the references to burden sharing. However, fairness and burden sharing can also be seen as being motivated by the lack of enough official money ("there is not going to be enough money to fill in all the gaps") and the moral hazard distortions of large scale bailouts ("creditors and debtors would be reckless if they knew that the official sector stands ready to bail them out systematically"). 
The basic logic behind the official approach to PSI was thus the need to finance external gaps, the limited availability of official money, and the need to avoid moral hazard distortions. The initial private-sector rejection of PSI in the financial community looks perplexing. Indeed, although the logic of PSI may have been quite uncontroversial, and even the private sector has reluctantly come to accept it, the application of PSI to specific cases has remained complex and controversial. The remainder of this section of the paper will make a broad assessment of the logic of PSI, the evolution of the official doctrine, its application to specific cases, and a wide range of open and controversial issues. ${ }^{34}$

First, note that the type of creditors, debtors, and instruments involved in crisis management and resolution and the degree of coerciveness of PSI has been very different in different crises in the 1990s (Mexico, Thailand, Korea, Indonesia, Malaysia, Russia, Brazil, Ecuador, Ukraine, Pakistan, Argentina, Turkey). At one extreme, there is the case of the 1994-95 Mexican crisis, in which there was no meaningful PSI of foreign investors because the amount of official resources provided by the IMF and the United States to Mexico was sufficient to allow all the foreign holders of short-term government debt (tesobonos) who were unwilling to roll over their instruments to exit from Mexico at maturity and with no losses. Very soft forms of PSI were implemented in the Brazilian case; in addition to a large package of official support, private cross-border interbank lines were first monitored (starting in the fall of 1998), and, next, international creditors committed to maintain interbank exposure to February 1999 levels. A similar but even softer form of PSI was implemented in Turkey, where the December 2000 IMF package was accompanied by a soft monitoring of crossborder interbank lines and a generic commitment by international investors to maintain such lines. In the case of Argentina there was no meaningful PSI of foreign investors in the IMF package of December 2000 because the amounts of official support committed to the country were sufficient for the government to avoid, if necessary, borrowing new funds from international

34. The discussion will concentrate on the role of PSI in crisis resolution while touching only marginally on the use of PSI for crisis prevention (which will be discussed in section 3.1.4). Appropriate PSI for crisis prevention partly overlaps with crisis resolution. If a rollover of interbank loans is arranged - maybe through ex ante coordination mechanisms such as creditors' committees - before asset prices such as exchange rates, stock prices, and sovereign debt prices have collapsed, one can think of this as crisis-preventing PSI. After the crisis is triggered, it becomes crisis-resolving PSI, but the substance of the problem is quite similar. Many proposals for crisis prevention could be discussed: capital controls, standstills, creditor committees, voluntary rollovers, private contingent credit lines. We will touch on these as part of our discussion of crisis resolution rather than crisis prevention, but a serious, difficult issue remains open. Ideally, one would want to involve constructively the private sector before, rather than after, the free fall of currency and other asset prices has caused recession, significant financial distress, and bankruptcy of sovereigns, corporations, and financial institutions. Thus, PSI for crisis prevention is preferable to that for crisis resolution. However, knowing how to avoid the crisis in the first place remains difficult. 
capital markets for most of 2001. However, there was some soft form of involvement of the domestic private sector as domestically based banks and pension funds committed in principle to purchase in 2001 determined amounts of government debt.

More coercive forms of PSI were implemented in Korea, Thailand, and Indonesia. In Korea, in December 1997, foreign bank creditors of Korean banks were trying to repatriate most of the short-term cross-border interbank lines amounting to about $\$ 20$ billion. However, faced with the risk of an imminent suspension of payments given that Korea and its banks did not have enough foreign reserves to finance such a roll-off, international banks first agreed to roll over such lines and then, in March 1998, to turn them into medium-term claims. This was a semicoercive form of PSI, formally a form of concerted rollover facilitated by the actions of the U.S. Treasury and the New York Federal Reserve. They helped to coordinate the collective action problem faced by the international creditors: international banks were effectively forced to accept the rollover and maturity transformation of their claims because of the country's lack of reserves to finance a roll-off of such lines. Restructuring of short-term international bank claims against the sovereign was implemented in Thailand and Indonesia even though the amounts at stake were much smaller than in Korea. In Indonesia the severe financial distress of corporates and banks also led to an effective standstill of private-sector liabilities to foreign investors (mostly corporate debtors given the larger exposure of the corporate sector to international banks).

In Asia, sovereign bonded debt issued internationally was minimal; thus, the PSI in these countries did not involve bonded debt. Sovereign bonded debt restructurings, instead, were part of the PSI policy in Pakistan, Ukraine, Russia, and Ecuador. Although the restructuring of these claims was, in the end, voluntary in the sense that unilateral exchange offers were made by the sovereign and accepted by a large fraction on bond creditors, there was a significant amount of coerciveness because these restructurings were preceded by effective default (nonpayment on the old instruments), as in Ecuador and Russia, or threat of default, as in Pakistan and Ukraine. Also, although Mexico, Korea, Indonesia, Thailand, Brazil, Argentina, and Turkey involved large official support packages together with policy adjustment and different degrees of PSI, the four bonded debt restructurings occurred in the context of smaller official support and large financing gaps. In Russia, the initially committed IMF package was large, but, given the country's inability to implement conditionality requirements, actually disbursed amounts were smaller and the country decided to default on a broad range of its claims against foreign investors.

The case of Malaysia was the only one not involving official creditors' support, because the country did not request an IMF package. Thus, the country's own decision to impose capital controls in September 1998 was 
not formally an application by the IMF and G7 of the official PSI doctrine. ${ }^{35}$ Such controls were, however, a form of standstills on some payments to foreign investors and will be discussed below in the section on standstills.

The official PSI doctrine has evolved over time. As discussed above, PSI was part and parcel of the official strategy to deal with the 1980s debt crisis including the Baker plan of 1985 and culminating in the Brady plan and its implementation in the early 1990s. The Mexican peso crisis of 1994-95, the first major capital account-based crisis of the 1990s, brought back the issue of whether and how appropriately to involve the private sector in crisis resolution. The effective bailout of private investors was ex post successful in that Mexico had been close to a liquidity run and that its economy rapidly and successfully recovered after official support. However, it led to the now familiar concerns about moral hazard, political limits to the size of official support packages, and the need for PSI. The G10 Rey Report came out in 1996 with recommendations about the need for CACs, IMF lending into arrears, and appropriate PSI. These recommendations were not implemented at that time, but the debate resurged in the aftermath of the Asian crisis. The crisis brought back the question of PSI, both in practice and as a doctrine. Before official doctrine was formally fleshed out, dealing with the crisis cases led to effective private-sector burden sharing in Korea, Indonesia, and Thailand. These cases were limited to cross-border bank loans (to financial institutions and corporates) and did not address the issue of restructuring bonds that were de minimis in these episodes. The official PSI doctrine was next developed as part of the attempt to reform the international financial architecture. The October 1998 reports of the G22 included one on PSI in crisis prevention and resolution. The formal $\mathrm{G} 7$ doctrine was fleshed out in early 1999 in preparation for the July 1999 Koln G7 summit, where PSI was addressed as one of the building blocks of the new international financial architecture. The Koln document on architecture reform included a large section on the new G7 PSI framework and doctrine.

This official doctrine can be characterized as a case-by-case approach with principles and tools. While the approach was case by case, a series of clear principles and tools were provided to clarify the process to be used in implementing PSI. Although some suggested the need for more precise rules to guide PSI, rigid rules were in the end deemed by the G7 as unrealistic. In this view, the complexity and novelty of the issues to be addressed did not allow a rigid set of rules. For example, under what circumstances would PSI be implemented? What kind of PSI would be appropriate in different cases: soft, semicoercive, concerted, coercive? What claims are to be included in PSI: bonded debt, short-term interbank flows, other short-

35. Formally, even the Russian case was not part of the official PSI policy because involving the private sector was not a requirement of the IMF program. The country decided on its own to default on some of claims. 
term credits, Eurobonds, Brady bonds, domestic debt (local and foreign currency-denominated)? What class of creditors is to be included: foreign, domestic, bondholder, bank creditors? How much adjustment and how much filling of external gaps are required? And how would the financing gap be filled between multilateral creditors (IFIs), bilateral official creditors ( $\mathrm{PC}$ creditors), and the private sector? How is $\mathrm{PC}$ comparability to be defined? How is the financing pie to be divided among different creditors? Is PSI to come before or after a PC rescheduling? What about reverse comparability? How to restructure sovereign bonds: via a market soundings process followed by unilateral debt exchange offers, or by relying on committees and formal negotiations between debtors and creditors? Should CACs be used or not? How much to micromanage the restructuring process? What to do in liquidity cases? How to distinguish insolvency from illiquidity? ${ }^{36}$ This is only a partial list of the very difficult questions that the official sector had to address in designing its PSI policy. Because many of these questions did not have a simple answer, in the view of the G7 the caseby-case approach-cum-principles and tools for PSI provided the correct balance between the need to provide clear guidelines to market participants and the need to maintain the flexibility of the policy to address specific cases.

The official doctrine has also stressed two other points that are of paramount importance. First, PSI should be "as appropriate." This bland word is intended to signify that, in the G7 view, whether and what type of PSI was needed would have to be considered by case-by-case study. Blanket rules suggesting PSI for all countries in crisis or for all countries that may have an IMF program would be avoided. In each case, the merit of appropriate PSI would have to be carefully assessed. Second, strong preference should be given to cooperative and voluntary solutions relative to more coercive solutions. Given the importance of enforcing international debt contracts and ensuring a steady flow of capital to emerging markets, semicoercive or coercive solutions would be considered only in extreme situations, and strong preference would be given to crisis resolution processes that are as noncoercive and as cooperative as possible. In the G7 view, the aim of PSI is not to punish or inflict losses on private-sector investors. It is rather to resolve, ensuring appropriate financing of external financing gaps and creating conditions that facilitate stable flows of capital to emerging markets and support long-run economic growth. At times, the private sector has perceived actions of the official sector as unfair, punitive, and unpredictable, but the G7 has argued that the whole PSI policy has been guided by an awareness of the importance of maintaining sound international capital markets and avoiding actions and policies that may disrupt flows of capital in undesirable ways. 
The difficult trade-off in official PSI policy was between the official desire to limit large money packages, while maintaining the option of having them when appropriate, and the desire to implement PSI policies that are as voluntary and cooperative as possible. This difficult trade-off is, for example, apparent from the first remarks of the new IMF managing director on the issue of PSI (Köhler 2000). On one hand, he suggested a preference for limiting large official packages; on the other hand, he strongly supported "constructive engagement" with the private sector, which implies, among other things, a preference for cooperative and voluntary, as opposed to semicoercive, solutions to crises. The two goals, while separately valid, are at times in dialectic tension with each other. Less official money might mean more PSI (and at times more coercive forms of PSI when voluntary ones are not feasible), whereas more voluntary forms of PSI or of constructive engagement might require more, rather than less, official money. This basic tension between the desire to limit official finance and the goal of having constructive and voluntary forms of PSI has not been fully resolved in official doctrine and practice.

During the same period that the official PSI policy was being fleshed out, developments in the policy arena led to the first cases of bonded debt restructuring.

First, the PC extended the comparability principle to bonded debt for the case of Pakistan in January of 1999. Although the principle was not new, it had not been applied before to bonds because they were de minimis in most cases. The restructuring of Pakistan's Eurobonds and other bonded claims was then successfully performed in the fall of 1999.

Second, the pressures on the Brazilian currency in the fall of 1998 that eventually led to the devaluation and float of this currency in January 1999 posed again the issue of whether and how to involve appropriately the private sector in crisis resolution. Cross-border short-term bank lines were, again as in Korea, at stake and in risk of no rollover. Moreover, a large stock of very short term domestic debt was also subject to rollover risk. Eventually, the form of PSI in Brazil turned out to be very mild with a system of monitoring of bank lines followed by a mild commitment in March 1999 to maintain exposures to February levels. Such mild PSI worked as the catalytic role of the official package, and the adjustment efforts of the country prevented a destabilizing loss of confidence and eventually restored economic growth without the need to resort to coercive outcomes.

Third, large external financing gaps and debt-servicing difficulties in 1999 by Romania and Ukraine led to attempts to restructure their bonded liabilities. ${ }^{37}$ Such attempts were ad hoc and only partially successful: PSI in

37. Strictly speaking, the first restructuring case was that of Ukraine in 1998. In that case, the instrument was not a classic bond but a structured financing (a local currency claim packaged with guaranteed access to foreign exchange from the central bank). This was not strictly a bond restructuring but certainly a restructuring of something that was not a bank line. 
Romania was attempted (the official policy was to consider bond restructuring but then to back down and let Romania pay its maturing instruments in return for a promise to raise new money) but eventually abandoned. The debt and bond restructurings in Ukraine (the structured note in 1998, the Dutch ING structured note in the summer of 1999, and a European Currency Unit-based claim in the fall of 1999) were first partial, ad hoc, and unsustainable over the medium term, as the strict market approach led to restructurings that were of very short maturity and at interest rates that were unsustainable in the medium term. Only later in 2000, did Ukraine take a comprehensive approach to its bonded debt restructuring (restructuring of Eurobonds and an assortment of Eurobond-like instruments created in earlier restructurings).

Fourth, the effective default of Russian debt following the August 1998 crisis led to a process that would eventually in 2000 restructure its bank and bonded liabilities. ${ }^{38}$

Fifth, the effective decision by Ecuador to stop payments on its external debt in August 1999 represented the first episode in which the previously restructured Brady bonds were effectively defaulted upon. This led to the need to restructure them (as eventually was successfully implemented in July/ August 2000).

Sixth, the drive to restructure bonds via market-based debt exchanges was successfully implemented in 1999 and 2000 in Russia and Ukraine (a comprehensive deal for Ukraine in 2000 rather than the ad hoc deals in 1998-99) after the successful Pakistani episode. And Ecuador's bonded debt exchange was successfully launched and completed in July/August 2000.

As these test cases played themselves out, the official doctrine evolved as well. Although the case-by-case approach was maintained and deemed appropriate given the complexity and differences of cases, the G7 agreed in April 2000 on a set of "operational guidelines" for PSI, in part as a response to private-sector requests for greater clarity. These guidelines were reaffirmed as part of the Finance Ministers Communiqué prepared for the July 2000 G7 summit in Fukuoka, Japan, and approved at the September 2000 IMF annual meetings in Prague.

One other general point is worth discussing at this stage. The form of PSI will depend on where a debtor country stands in the broad spectrum that goes from pure "liquidity" cases to pure "insolvency" cases. This is a most complex issue. First, deciding whether a country is insolvent or not is very hard, given that debt servicing depends on both ability to pay and willingness to pay. Second, the spectrum of cases is not limited to corners of pure

38. First, there was the default on GKO and nondeliverable forwards in August 1998. Then, cascading defaults on Ministry of Finance bonds (Min Fins), Prins, Ians, and other Soviet-era debt eventually lead to a restructuring of a broad range of external and domestic London Club and bonded obligations. 
illiquidity and pure insolvency cases but is more gray and continuous. Often, countries that are mostly illiquid have significant policy problems (such as Mexico in 1994 and Korea in 1997), so that a simple solution such as full unconditional large official support without any PSI may not be feasible. At the other end, countries that look insolvent (for example, Ecuador) may eventually be able to service their restructured — rather than reduced - debt if they implement enough policy adjustment. In between the cases of liquidity (with or without policy problems) and the pure cases of insolvency, there are many cases of countries with significant macro and structural adjustment problems whose debt burden may not be unsustainable in the long run but who do face significant payment humps in the short run (Pakistan, Ukraine, Romania). In these cases some form of PSI short of outright debt reduction may be adequate to solve the payment problems of these countries.

One could argue that the severity of the PSI policy will depend on where a country stands within this spectrum. Debt reduction is inevitable for clear cases of insolvency subject to a country's effort to adjust its underlying problems. Debt restructuring, rescheduling, and rollovers that do not formally touch the face value of principal payments may be warranted in cases in which severe policy problems exist and the debt burden is not unsustainable but payment humps and lack of market access do not allow the country to service its debt in full and on time in the short run. ${ }^{39} \mathrm{~A}$ solution closer to large official support packages (full bailout) may be warranted because of favorable externalities in cases of pure illiquidity, especially if the country is large and of systemic importance. However, as we will discuss in detail in section 3.1.6, the role of PSI in such liquidity cases is a more complex issue than this simple logic suggests.

\section{Moral Hazard}

The issue of moral hazard in international capital flows has been hotly debated. Moral hazard in this context has to do with the potential distortions deriving from implicit or explicit official guarantees of debts and the potential effects of official creditors' support packages. Because one of the fundamental rationales for PSI is the idea that excessive official support may lead to moral hazard, it is important to assess the importance of this distortion in international capital markets.

Some definitional distinctions are important. One can be concerned

39. Even in such cases, the restructuring will imply some NPV reduction of the debt as interest rate and principal payments will be rescheduled at rates that are below current market rates. Thus, some real debt reduction will occur and does occur even in cases without formal reduction of face value. As official bilateral claims are also rescheduled at rates that do not truly reflect repayment risk, PC debt is also subject to effective NPV reduction even if it is not formally written down. This was discussed in more detail in the section "Modalities of Coordination." 
about the debtor's moral hazard or the creditor's moral hazard. The debtor's moral hazard arises if official money (in the form of multilateral and bilateral lending and support) reduces the incentive of a debtor to follow sound policies in the first place and affects its incentives regarding payments on its external liabilities to foreign private investors. Even within the class of debtor moral hazard, one may want to distinguish between the moral hazard of the sovereign and the moral hazard of domestic private agents. The latter refers to the case in which implicit or explicit government guarantees lead domestic agents in emerging markets (financial institutions, corporations, and households) to borrow excessively (directly or indirectly from foreign creditors) relative to what would be optimal and to make distorted investment decisions. The debtor government's moral hazard derives instead from expectations that some external official agent (multilateral or bilateral official creditors) will provide bailout support to the country, thus leading ex ante the sovereign to follow loose economic policies that may eventually cause economic and financial problems. The creditor's moral hazard refers to the distortions in the lending decisions of international creditors that derive either from expectations that the official creditor sector will bail out a sovereign or from expectations that a sovereign will ex post guarantee liabilities of its private sector that have been incurred with private international creditors. ${ }^{40}$

There is a broad range of views on the analytical and practical importance of moral hazard distortions in international capital flows. Some, such as McKinnon and Pill (1997), Calomiris (1998b), Schwartz (1998), Dooley (2000b), Chinn, Dooley, and Shrestha (1999) and Corsetti, Pesenti, and Roubini (1999a,b) believe that such distortions are critical, whereas others, such as Summers (2000) and the Institute of International Finance (IIF; 1999c), think that such distortions are less important than others have made out. The issue is obviously one of quantitative degree rather than absolutes. Official response to crisis always has the potential to lead to moral hazard; the issue is how important the distortion is.

The different views on moral hazard and the determinants of the flows to emerging markets in the 1990s are hard to test. ${ }^{41}$ Formal and systematic evidence is scarce. There are, however, a few recent econometric studies. A paper from the IIF (1999c) attempts to test formally for moral hazard by trying to assess whether the significant reduction in sovereign spreads in the period before the Asian crisis can be explained by fundamentals or could be

40. Even when governments have declared ex ante that they will not guarantee private claims, they are often nonetheless forced to take responsibility when the time comes. Chile in the early 1980 s was a case in point. Korea's guarantee of cross-border banks' liabilities in late 1997 is another example from the recent Asian crisis. More recently during the NovemberDecember 2000 turmoil in its markets, Turkey decided to guarantee all bank liabilities, including cross border.

41. See Roubini (2000) for a more detailed discussion of these arguments. 
related to bailout expectations following the Mexican rescue. This study does not find evidence of moral hazard. Lane and Phillips (2000) consider whether IMF programs are a source of moral hazard. They find that this type of moral hazard is difficult to detect in market reactions to various IMF policy announcements, and there is no evidence that such moral hazard has recently been on the rise. Dell'Ariccia, Goedde, and Zettelmeyer (2000) have also tested for moral hazard by considering sovereign spreads and their variance before and after the Russian crisis; they find partial, and mixed, evidence of moral hazard in this episode. More circumstantial evidence suggests that investors may have expected large official support packages for systemically important countries in recent episodes of financial turmoil such as Russia in 1998, Brazil in 1998-99, and Argentina and Turkey in 2000.

Both debtor moral hazard and creditor moral hazard deriving from expectations of bailout via official support are important enough to be a concern for the design of an efficient international financial system. Moral hazard affects issues such as the desirability of an international lender of last resort, the optimality of official support packages, and the issue of whether and what form of PSI is appropriate. The overall analytical and empirical evidence suggests that the moral hazard rationale for PSI is a valid argument for appropriate forms of PSI in crisis resolution.

\section{Issues with Standstills}

Several authors have suggested that some broad debt standstills (suspension of debt payments) may at times be necessary, either to prevent a period of turmoil from turning into a full-blown crisis or to prevent further overshooting of asset prices and the risk of an outright default once a crisis has occurred. This is certainly a most controversial issue. Support for the idea of standstills comes not only from academic economists but also, cautiously, from some official-sector representatives within the G7 (see, e.g., King 1999). ${ }^{42}$

A standstill, if temporary, can be seen as a radical form of bailing in the private sector, and, according to some, it is a better and more orderly way to gain time and restore confidence than a disorderly rush to the exits. A standstill could be the right policy response both in liquidity cases when there is an "irrational" rush to the exits and in other crisis situations, when serious policy problems are afflicting the debtor country but the rush to the exits of creditors is disorderly and threatening to create a worse outcome.

Standstills pose a lot of complex questions. What are the risks and benefits of standstills? Would they include only sovereign payments or payments on all the debtor country's claims, including by the private sector? Do

42. See IMF $(2000 \mathrm{a}, \mathrm{b})$ for a discussion of standstills and the debate on them at a recent IMF board meeting. 
standstills require systematic capital and exchange controls? Should they be sanctioned by the IMF or the official sector? Could they be associated with a stay of litigation?

Consider the potential benefits of standstills. In pure liquidity cases in which there is uncertainty and no risk aversion, the threat of a standstill is enough to support the good equilibrium: that is, ex post there is no need to implement the threat, and agents will avoid rushing to the exits if they know that everyone would be locked in. ${ }^{43}$ In reality, uncertainty, risk aversion, and policy problems make this first best equilibrium unlikely, and standstills would have to be introduced (rather than just threatened) to prevent investors from rushing to the exits.

If standstills have to be imposed, what are their benefits? The main benefit may be to prevent a disorderly rush to the exits when, even allowing that the country may have serious policy problems, investors panic and overreact to the negative developments. Such a disorderly rush is inefficient for two reasons: First, it may force the debtor into effective default (inability to make debt payments) when, even if solvency is not at stake, the stock of foreign reserves is below the short-term claims that are coming to maturity and are not being rolled over. Second, when the exchange rate is allowed to float rather than being fixed, the rush to the exits may lead to severe overshooting of the exchange rate. That, in turn, may be extremely costly if it leads to financial distress and bankruptcy of a large set of debtors, sovereign and private.

Take, for example, the cases of Korea and Indonesia. If the concerted rollover of cross-border interbank loans in Korea had occurred by Thanksgiving 1997 rather than a month later at Christmas, widespread financial distress would have been limited. The difference between the two dates is that, at the former, the exchange rate of the won to the U.S. dollar had fallen from 900 to 1,100 (beneficial in terms of competitiveness), whereas by Christmas it had fallen to over 1,800 (causing widespread financial distress). Although many chaebol were already distressed earlier in 1997 before the fall of the won, 1,800 was a rate at which many more foreign currency debtors, financial firms, and corporates were effectively distressed if not bankrupt. Thus, the implication of the delay in the concerted rollover was a significant worsening of the financial conditions of Korea and a worsening of the real output effects of the exchange rate shock.

In the case of Indonesia, some have argued that the lack of an early standstill on payments by the local corporates to their international creditors contributed to the free fall of the currency. The collapse in the value of the currency, particularly the move of the exchange rate of the rupiah to the U.S. dollar from 4,000 to 8,000 and then 12,000 (and above) led to the wide-

43. See the section "International Lender of Last Resort" for a broader discussion of standstill and other issues in liquidity cases. 
spread effective bankruptcy of most financial institutions and firms in the country. At the end, the burden of foreign debt was so high, given the fall in the value of the currency, that these corporates effectively stopped payments. An informal standstill of corporate liabilities occurred by default in a situation of complete financial distress of these firms.

The above arguments suggest that an early standstill might have helped to minimize the costs of further turmoil that derived from a lack of orderly workouts. The reality, however, is more complex. In the case of Indonesia one could argue that the depreciation of the rupiah had less to do with the attempt of corporates to hedge their foreign currency positions than with government failures that shook confidence in the country. The lack of commitment to structural reform, the political uncertainty, the health of Suharto, his crumbling power regime, the monetization policy of Bank of Indonesia, and the capital flight of the ethnic Chinese who were exposed to violent attacks were all more important than hedging demand in driving the rupiah into free fall. In the absence of a more serious and credible adjustment program, it is likely that a standstill would not have worked out and would have failed to stem the fall of the rupiah and the generalized panic that enveloped domestic and foreign investors. Flight and asset stripping might have continued even under strict capital and exchange controls, given the many sources of leakage in capital flows. Thus, it is not obvious that a standstill on private payments would have worked. Also, standstills on payments by private firms are harder to arrange than on sovereign payments. The difficult issues include who will declare one and how to enforce it.

Again, in the case of Korea, it is not clear that a standstill would have worked. The won started to fall precipitously in early December when, in spite of an IMF program, a series of bad news hit markets: the low level of reserves was revealed, the extra offshore liabilities of Korean financial institutions and chaebol emerged, the upcoming election and the policy uncertainty around it became important sources of uncertainty and of concern about the willingness of the government to implement reforms credibly. Also, all the players in the game - international creditors, the Korean government, and official creditors - were not ready early on to go for a concerted rollover. It was only when - at the end of December - it became clear that Korean banks were on the verge of defaulting on their liabilities that a concerted rollover became feasible and acceptable to creditors.

The case of the Malaysian capital controls in September 1999 was not formally a case of implementation of PSI as part of a package of official support, because the country did not request an IMF package and did not rely on official creditor financial support. Instead, the country decided to impose capital controls as a way to regain monetary autonomy in the presence of large pressures on its currency. Some of the capital control measures (such as closing down the offshore ringgit market) did not formally represent PSI; others, such as the temporary restrictions to foreign investors' 
ability to repatriate portfolio investments in Malaysia, were a clear form of coercive bailing in of foreign investors. Note that Malaysia did not impose a standstill on sovereign debt payments, but these liabilities were negligible to begin with.

Standstills have a number of other potential drawbacks that need to be considered.

First, standstills may reduce in the medium to long run the amount of capital flowing to emerging markets if they are perceived to be a tool used by debtors to opportunistically default on their debt obligations.

Second, as in the case of anticipated capital controls, anticipations of a standstill may lead to an earlier crisis (as all investors rush to the doors in expectation that the doors will be shut); or, worse, they can even trigger a crisis that otherwise would not have occurred. This is the main drawback, one that cannot be avoided if there are clear rules that imply some automatic standstills in some circumstances. Constructive ambiguity in place of rules may help, but if investors fear that standstills will be imposed with some probability (even without mechanical rules), the rush to the exits may occur anyway. Proponents of standstills have not seriously addressed this main shortcoming of the tool. For example, it is clear that the Korean concerted rollover in December 1997 led investors to believe that such semicoercive policy might be imposed on Brazil as well. The sharp reduction in interbank exposures to Brazil in the summer and fall of 1998 was clearly affected by the experience of Korea - and that of Malaysia in September 1998 - and expectations that similar coercive solutions might be imposed in Brazil. In the case of Malaysia, capital controls of the type that were eventually imposed in September 1998 were widely predicted throughout 1998 as being likely to be implemented. Thus, some of the capital flight and pressures on the currency in 1998 were caused by the expectation of controls. However, the breadth and extent of these controls somewhat surprised investors once they were imposed.

Third, and related, standstills risk international contagion. Contagion may occur either because investors start to expect that such standstills may be imposed on other countries or via the financial contagion channels that the literature has highlighted (common creditor effects, proxy hedging and cross-country hedging, proxy plays, increase in risk aversion of investors, portfolio adjustment effects). The Russian default and imposition of capital controls by Malaysia clearly produced a severe contagion effect in the summer and fall of 1998.

Fourth, partial standstills may not work. They may have to be extensive and widespread. A standstill on sovereign payments probably has to be comprehensive to be effective; otherwise, claims not included will be tempted to flee. Similarly, standstills on sovereign claims alone may not be enough, for several reasons. First, as in Korea and Indonesia, the claims of domestic banks and corporates can be the source of reserve loss and cur- 
rency depreciation. Second, standstills on sovereign payments may not close the financing gap if private claims can also flee and the existence of a sovereign standstill leads private investors to worry that a broader stay of payments will soon be imposed on them.

Fifth, as a consequence of the point above, broad capital controls and exchange controls may have to be imposed that restrict the payment ability of private agents in the economy. ${ }^{44}$ Under fixed exchange rates, since all liquid claims - even those in domestic currency — can be turned into foreign assets, widespread capital controls may be necessary to reduce the pressure on official reserves. Under flexible rates, the same attempt of the private sector to turn domestic assets into foreign ones will lead to a sharp currency depreciation that is potentially very harmful if there are many foreign currency liabilities. Thus, again, broad capital and exchange controls may be necessary to prevent an overshooting of the currency and other asset prices.

Sixth, standstills on payments of domestic private agents, especially corporates, are difficult to arrange; they effectively imply the imposition of capital and exchange controls. The controls may lead, as the experience of Indonesia shows, to perverse effects such as "asset stripping." It is one thing to impose controls to avoid a destabilizing rush to the exits; however, if such controls are used for strategic avoidance of sustainable debt payments or to strip the assets of the underlying firms, the effects may be perverse. Thus, some form of standstill may make sense in countries where there is an efficient and functioning insolvency and corporate restructuring legal system. But it can have perverse effects in countries where, because of inadequate institutions, corruption, and archaic legal systems, creditors cannot seize firm assets and prevent asset stripping.

Seventh, formal standstills present complex legal issues. The main problem is whether a standstill can prevent litigation aimed at seizing the assets of the debtor. One solution would be to provide such a power to the IMFthe power to sanction broad standstills. It is, however, agreed that providing such a power to the IMF would require amending Article VIII.2.b of the fund's Articles of Agreement. There is significant political resistance among the main fund creditors to take a route that would provide the IMF with such authority. All sorts of economic and institutional concerns have been expressed even though several influential voices have expressed support for such a change (including that of former IMF Managing Director Camdessus and other official sources).$^{45}$

44. Malaysia is an example of the imposition of capital controls as way to prevent domestic residents' capital flight and as a way to lock in foreign investors trying to exit from their long local portfolio investments.

45. In the absence of a legal mechanism to provide the IMF the power to sanction a standstill, debt suspensions by a sovereign or private-sector entities (whether within or outside official PSI policies) are subject to litigation risk. For example, creditors accelerated their claims once Ecuador defaulted on its Bradies, but then they did not pursue legal action to enforce their claims. 
In the absence of such an amendment, the issue is whether, in the presence of a standstill informally sanctioned by the IMF with a policy of lending into arrears, a court would provide a stay of litigation (preventing litigation aimed at seizing the assets of the debtor), especially if the debtor is cooperatively working to work out its payments with some of its creditors. Although there is some limited legal precedent in the United States for courts' imposing such stays, it is an open issue whether such a stay could be legally imposed as a temporary tool aimed at allowing an orderly workout. Also, while threat of litigation is an issue, occurrences of litigation in practice may be limited, especially because the ability of creditors to seize the assets of sovereign and private debtors in emerging markets is limited. The costs of litigation may effectively reduce the occurrences of such a problem.

In spite of serious shortcomings with formal debt standstills, one cannot rule out the possibility that, in some circumstances, their benefits may outweigh their costs. Thus, although having formal rules that determine when a standstill may be introduced would be counterproductive if they triggered the rush to the exit that one wants to avoid in the first place, one cannot rule out their use in extreme situations. Some degree of constructive ambiguity may be helpful in this regard even if the uncertainty over whether, how, and how widespread a standstill is likely to be would in other respects be counterproductive. Temporary, targeted standstills in situations in which a real commitment to policy reform exists (but is not fully credible to market participants) may be a useful part of the tool kit of crisis prevention and resolution. ${ }^{46}$ However, such a tool needs to be used with extreme care to prevent consequences worse than the problems that it is aimed to cure.

\section{The G7 PSI Framework and Its Application to Bonded Debt Restructurings}

We discuss next the many aspects of the PSI official doctrine and practice as emerged in a number of recent case studies (Pakistan, Ukraine, Romania, Ecuador, and Russia) $)^{47}$ of sovereign bonded debt restructurings. These recent episodes have involved countries that are small (nonsystemic, with perhaps the exception of Russia) and where restructuring of bonded debt has become an element of the PSI in crisis resolution. Indeed, bonded debt restructuring is a relatively new, controversial, and complex issue. Thus, we will discuss the many issues that have emerged in applying PSI to the case of bonded debt and other similar securities. The official PSI doctrine can be

46. Korea's concerted rollover could be seen as such a targeted standstill in the context of a credible adjustment program, whereas Malaysia's capital controls were much more coercive in their nature and implementation and not linked to an explicit policy adjustment plan.

47. Strictly speaking, the Russian debt restructuring in 2000 was not a case of application of the PSI doctrine but resulted from the decision of the country to restructure again its old restructured London Club bank claims, the Prins (bonds issued in exchange for old 1997 London Club principal) and Ians (bonds issued in exchange for interest arrears on 1997 London Club debt) and the past due interest claims. 
characterized as a case-by-case approach-cum-principles and tools. Note that such doctrine applies not only to bonds but also to overall claims of a debtor country (including bank claims). However, the framework has been recently applied to many bonded debt restructuring cases.

\section{Collective Action Clauses and Voluntary Debt Exchanges}

All of the recent episodes of sovereign bonded debt restructurings (Pakistan, Ukraine, Ecuador, and Russia) have made a very limited use of CACs before such bonded debt restructurings occurred (via voluntary exchange offers). But strong arguments were made that bonded debt restructurings would not be feasible without CACs such as collective representation mechanism for creditors, majority clauses to change the terms of bond contracts, and sharing clauses. The arguments in favor of and against CACs are by now familiar and the views on CACs of official creditors, the private sector, and debtors quite known. Collective action clauses were first proposed in the Rey Report as a way to facilitate the restructuring of bonded debt. Next, both the official sector in its expressions of PSI doctrine (see Koln G7 Summit Architecture Communiqué) and academics (such as Eichengreen, Portes, and many others) extolled their benefits. It was argued that the lack of such CACs would make it very hard, if not impossible, to restructure bonds. Lack of collective representations mechanisms (such as bondholder committees, trustees, and similar coordination mechanisms) would make it hard to coordinate actions of a multitude of dispersed bondholders and implement restructurings. Lack of majority clauses would require unanimity in the decision to change the terms of the bond contract and would hold a possible large majority of bondholders willing to restructure hostage to a possible miniscule minority of holdouts and vulture creditors. Lack of sharing clauses - which require the sharing among all creditors of proceedings obtained by the litigation action of a subset of creditors - would open up room for disruptive litigation by a small group of litigious holdout creditors. ${ }^{48}$

The differences between bonds issues under U.K. law and those issued under New York law were also highlighted by many: the former effectively had collective representation, majority, and sharing clauses (especially trustee bonds), whereas the latter did not. Collective action clauses (especially their being mandatory in international bonds) were first strongly resisted by the private sector. In this view they would make restructuring too easy and would thus tip the bargaining power balance in favor of debtors

48. Note that London Club debt—-syndicated bank loans-implied implicit and explicit forms of collective action clauses: syndicated loans required the formation of creditor committees to represent the interests of creditors, thus solving the collective action problem of coordinating creditors' action; they included effective majority clauses because a majority of creditors could decide to restructure their claims while such actions were not necessarily binding on minority holdout banks; and, often, they included formal sharing clauses. 
with the risk of making defaults more frequent (strategic opportunistic defaults based on unwillingness to pay rather than inability to pay) and thus eventually undermining new debt flows to emerging markets. Borrowing countries too were concerned that such clauses would taint their reputations. Emerging market economies were wary of CACs' being forcibly imposed on their debt contracts under the concern that spreads on such instruments would be higher. On the other hand, it was argued that spreads would instead be higher for instruments where restructuring was very hard, because the costs of necessary restructuring would be too high. Next, some academic research (Eichengreen and Mody 2000a,b) suggested that, actually, spreads for good credit countries are lower on bonds with CACs, but higher for poorer credit countries. ${ }^{49}$ Thus, the benefits of reducing restructuring costs outweigh the penalty for possible opportunistic default for good credits. Academics (Eichengreen and Ruhel 2000; Eichengreen 2000; Portes 2000) also sharply criticized the ad hockery of the case-by-case approach to PSI and argued that CACs would have provided a much more transparent and simple approach to all PSI problems.

In spite of these arguments in favor of CACs, recent experience with bonded debt restructurings suggests that, although CACs may be marginally helpful in facilitating such restructurings, their usefulness has been somewhat exaggerated. In all recent cases of bond restructurings (Pakistan, Ukraine, Russia, and Ecuador) CACs have had a very marginal role. First, note that all these debt restructurings have occurred through unilateral "debt exchange offers" rather than via the formal use of CACs even in cases in which, as in Pakistan and Ukraine, the instruments included CACs. The use of unilateral debt exchange offers obviates the need for CACs because such an offer is voluntary and can be made regardless of the existence of a majority clause or other CACs. Thus, one can envision a system in which debt exchanges are the norm and the CACs are neither needed nor used when available. Collective action clauses have been marginally helpful only in two cases: in Ukraine, where three out of four restructured instruments had CACs, such clauses allowed the ex post "binding in" of holdout creditors after a vast majority of bondholders (over 90 percent) had accepted the terms of the offer. Thus, they were used ex post rather than ex ante to lock in holdouts and prevent disruptive litigation. In the case of Pakistan, where restructured bonds all had CACs, such clauses were not used either ex ante or ex post. However, one could argue that they were somehow useful, in that the possible threat of their use may have convinced some undecided creditors to accept the exchange offer. In Russia and Ecuador, debt restructurings were performed without any CACs because the underlying instrument did not have such clauses. In the case of Ecuador, however, legal ways were 
found to dilute the litigation benefits of holdouts by the use of "exit consent" amendments. Thus, worse terms were "crammed down" on holdouts.

Thus, exchange offers have been the norm in bond restructurings so far, and CACs have not been used ex ante to force the restructuring even when instruments including them were available. Why didn't CACs turn out to be essential for successful restructurings in the way that had been suggested by many? ${ }^{50}$

One first answer is that exchange offers allow a restructuring of bonded debt even in the absence of any CACs. Litigation risk by holdouts is an issue to be considered in these cases, but experience, so far, has been that such risk has been limited, for reasons to be discussed in more detail below. Thus, exchange offers provide an effective alternative to CACs as a tool to implement bonded debt restructuring. Also, when available ex ante, CACs can be used in a second round if an exchange offer were to fail; so they are an instrument of second resort rather than first resort in bond restructurings even when available.

Second, debtors and debt agents (such as trustees) are obviously wary of the idea of using collective representation clauses (such as creditor committees) and majority clauses because they are concerned that even just calling a meeting of bondholder creditors may lead to undesirable outcomes. Such meetings may start a protracted negotiation process that may take too long; it may allow creditors to coordinate their decisions and take legal action against a debtor. In reality, no debtor or trustee would want to call a meeting of creditors unless previous market soundings and bilateral meetings with creditors have allowed these agents to figure out all the details of a possibly successful debt exchange offer. Thus, the model of debt exchanges without use of CACs - in which financial and legal advisors of the debtor make broad market soundings before the offer is launched to figure out which terms will maximize the probability of a successful offer-can avoid a potentially disruptive, long-delaying formal negotiation under creditor committees and via the use of CACs.

As suggested above, the model of "debt exchanges-cum-market soundings" has successfully worked so far in all bond restructuring cases, and the role of CACs has been either to provide a tool to bind in holdouts ex post or to threaten credibly their use in case an exchange offer does not work. This experience also suggests that academic critiques of the current PSI process as being ad hoc and inferior to one with CACs turned out to be a bit off the mark. Collective action clauses are only an empty shell that may or may not facilitate a restructuring process. They are not, by themselves, a tool that provides ex ante the answer to the complex set of questions (when, how, how much, which assets, which creditors, in which sequence) that have to be addressed when trying to restructure bonds. Collective action clauses

50. See Eichengreen and Mody (2000b) for a recent defense of CACs. 
do not provide ex ante an easy tool through which these questions can be answered and solved in practice.

\section{Lessons from Recent Cases of Bonded Debt Restructuring}

Bonded debt restructurings have occurred since 1999 as the direct outcome of the adoption of the new G7 official PSI policy. Successful recent case studies include Pakistan (the first case of an application of the PSI policy, because the $\mathrm{PC}$ requested a restructuring of the private bonded claims of Pakistan on comparable terms to the restructuring of PC claims), Ukraine (where the official sector nudged the country to restructure its sovereign bonded claims as an implicit condition for an IMF program), and Ecuador (where the official sector effectively sanctioned the country's decision to suspend payments on its Brady bonds in the face of an unsustainable external debt-servicing path). In all these episodes, bonded debt restructuring was the effective outcome of the G7 policy to include bonded debt among claims to be restructured when a country suffered severe debt servicing problems. Russia successfully restructured its Principal Interest Notes (Prins) and Interest Accrual Notes (Ians), but this was not formally part of the official PSI policy (but, rather, the result of the country's decision to restructure its liabilities). In Romania, PSI was attempted but eventually abandoned as the country made payment on maturing debt and then was unable to raise new money as required by the PSI components of its IMF program.

What are the lessons learned from these restructuring cases? Although the sample of cases is limited (Ukraine, Ecuador, Pakistan, Russia, and the failed attempt to impose PSI in Romania), one can suggest a number of tentative lessons.

First, debt exchanges (following extensive market soundings) are an operational alternative to the use of CACs or formal negotiations. In all these episodes CACs were not used ex ante, and the benefit of their existence was only the ex post ability to "cram down" new terms on holdouts (as in Ukraine) or threaten their use (as in Pakistan). Even in the case of Ecuador, where there were no formal CACs in the old restructured instruments, the legal advisor found legal ways to cram down new terms on the holdouts to make the old bonds less appealing to the holdouts. Note that although Ecuador's bonds required unanimity to change payment terms, only a simple majority of 51 percent is required to change nonfinancial terms. Thus, "exit consent" for those who accepted the deal were used to change the terms of the old bonds and make them less appealing to potential holdouts.

Second, all these deals provided mark-to-market gains to investors, in that the terms of the deals were generous and included various sweeteners. Such sweeteners included financially favorable terms for creditors, informal upgrade in the seniority of the claims (in Russia), substantial up-front 
cash payments (Ukraine, Ecuador, Russia), and Brady collateral release (Ecuador). Indeed, some have argued that such deals were very generous to investors because they led to sharp gains evaluated at market prices relative to the predeal prices of the restructured bonds. Such gains were equivalent to over 20 percent for Ukraine, 32 percent for Russian Prins and 18 percent for Russian Ians, 3.5 percent for Pakistani bonds, and averaging over 30 percent (based on the jump in the price of Brady Bonds, PDIs, and euros after the deal was announced) for the case of Ecuador.

Third, the reasons for the mark-to-market gains after the deals were announced are not fully clear. Some argue that the gains were due to the better-than-expected terms of the deals, but if a country's debt price depends on its ability to pay, it is not clear why unexpectedly generous terms would affect that price. Some explanations are that a better-than-expected deal signals something about the country's desire to make more adjustment than otherwise or more commitment to attempt to keep the new payment profile (as debt prices depend not only on the ability but also on the willingness to pay). Other explanations are that the deal implies that the official bilateral creditors will bear a greater burden and the private sector will thus bear a smaller burden; the new instruments have or are perceived to have a greater seniority than other instruments, although this effect on the price is rational only if official creditors or other private creditors who are not in the bond deal are worse off as a consequence of the deal; the up-front cash in most of these deals (very significant in Ecuador as the Brady principal collateral was to be released to creditors) was a positive surprise that effectively gave senior payment treatment to investors who took the deal because cash today is much more valuable than a promise of payments down the line. But if this is the case, whoever gets cash first does so at the expense of future creditors (probably official ones), who are likely to be hurt by the deal. Thus, in most cases, the jump in price signals a deal that made some creditors better off, most likely at the expense of official creditors.

Fourth, it is not obvious that in all cases medium-term debt sustainability has been restored. For cases of countries such as Pakistan or Ukraine where the overall external debt burden was not unsustainable (i.e., the country was not insolvent), a restretching of payment terms allowed avoiding the payment humps and, subject to successful economic reform, the debt profile may become sustainable. Similarly, the default by Russia and restructuring of its external and domestic debt is likely to have put the country on a path of solvency. The same may not be said of the Ecuador deal, whose terms were quite favorable to creditors. Even after the deal is concluded, and even assuming the most optimistic scenarios for domestic adjustment, the country is likely to end up in the medium run with a debt-GDP ratio of around 100 percent and a debt-exports ratio and a debt-government revenues ratio that are well above the official HIPC criteria for significant debt reduction. Although the country's GDP does not allow it to qualify for 
HIPC relief, it is likely that the country will remain with debt ratios that are possibly unsustainable. Moreover, considering that the assumptions about fiscal adjustment and trade balance adjustment embedded in the IMF program are the most optimistic in terms of intensity of the country's policy adjustment, any slippage in performance will make such ratios much worse. One could argue that the country has only delayed for a few years its debtservicing problems and that further debt restructurings will occur as the current debt profile may keep the country insolvent.

Fifth, as the unsuccessful experience with PSI in Romania suggests, attempts to expect "new money" at below market rates from creditors as a form of PSI do not work if the country has lost market access and is allowed to make large debt payments that are coming to maturity. In 1999, Romania, facing \$720 million of payments, was allowed by the IMF to use dwindling reserves to make such payments under the condition of raising 80 percent again in new money ( $\$ 600$ million). Once the payment had occurred, the country lost any leverage (nonpayment threat) over creditors, and the IMF and G7 lost their ability to nudge the country to an involvement of the private sector in sharing the burden of external debt adjustment. The subsequent attempts to raise $\$ 600$ million were sequentially diluted in the face of the country's lack of market access; thus, eventually the IMF waived the PSI requirement in an obvious failure to implement the PSI policy for that country.

The country then bore the consequences of its decision to make the payments on its external debt. The domestic adjustment was deeper than necessary, with output falling in 1999 and early 2000 more than otherwise possible. The subsequent buildup of reserves in 2000 - earlier depleted by the large 1999 debt payments - was made at the cost of a substantial and sharp contraction of imports that was feasible only with a sharp contraction of output. Thus, the decision of the country not to restructure its external debt (which was sustainable in terms of its size but characterized by a very lumpy payments profile in the short run) was thus paid for with high real costs.

Stated official PSI doctrine is that the official sector should not force a country into nonpayment but should rather make clear to the country the consequences of continuing to pay when restructuring may be warranted according to the IMF. That is, the official PSI doctrine implies that continuing debt payments in these cases will imply a greater amount of domestic adjustment, not greater amounts of official support. In reality, however, debtor countries may still make decisions - continue payments - that eventually shift some of the debt burden onto official bilateral creditors (PC claims) or lead to greater-than-otherwise-planned multilateral support. In practice, official bilateral and multilateral support may effectively grow ex post in spite of ex ante official statements to the contrary, or the terms of the IMF program may become effectively more lax to allow breathing space to the country. 
Sixth, the official sector has indicated that bonded debt restructurings should be evaluated by the IMF to ensure that their terms are comparable to $\mathrm{PC}$ restructurings and consistent with medium-term debt sustainability. This means for the IMF to assess the financial terms of these deals, the amount of up-front cash, the upgrade in seniority terms, and the implications for medium-term sustainability in deciding whether such deals are consistent with an IMF program. Note that the current system of incentives and the financial interests of advisors and debtors result in deals that turn to be financially beneficial to private creditors (as suggested by the jump in prices of the old debt in all recent exchanges) but may imply some burden shifting to official-sector claims. Financial advisors are interested in generous deals because they maximize the probability of success (reduce "deal risk"), increase the fees and commissions that are conditional on a successful deal, and reduce the burden sharing for the buy side of their firms (which hold the old bonds) while the sell side is involved in underwriting and successfully placing the new bonds.

Thus, although the official doctrine suggests that the official sector should not "micromanage" debt restructuring, some systematic way to assess whether a deal is appropriate should be developed. It is true that the generosity of the deal may be required at times to ensure its success. In Ukraine, up to 100,000 creditors had to be convinced to accept the new bonds. In Ecuador, up-front cash, on top of the collateral release, was necessary to give incentives to PDI and euro bond holders because such claims did not have collateral. Upgrade of seniority made the Russian Ians and Prins deal more palatable to creditors, and so on. However, the issue that the IMF is mandated to assess is whether the terms of such deals are consistent with the overall adjustment program of the country and the mediumterm sustainability of its external debt.

Seventh, an alternative strategy has been to reduce the face value of debt, as in Ecuador, where the judgment was made that the country was insolvent. In other cases (Ukraine, Pakistan, Romania) where it was not clear whether the country was insolvent or rather facing illiquidity given the lumpy debt payments coming due, a rescheduling/restructuring rather than face-value reduction was attempted. Even in such cases, the restructuring did imply some NPV reduction of the debt as interest rate and principal payments were rescheduled at rates that were below current market rates. Thus, some real debt reduction occurred even in cases in which face-value reduction was not formally performed. As official bilateral claims are also rescheduled at rates that do not truly reflect repayment risk, PC debt is also subject to effective NPV reduction even if it is not formally written down. Comparable treatment of official bilateral and private claims is thus possible only in approximate terms because exact comparability is hard to define. In this regard, the Pakistan exchange was broadly comparable to the 
PC deal. Other cases (Russia, Ukraine, Ecuador) cannot be assessed because private claims rescheduling preceded $\mathrm{PC}$ rescheduling.

Eighth, while a normal or standard restructuring sequence would have seen, as in the 1980s, an IMF program followed by PC rescheduling of official claims followed by London Club rescheduling on comparable terms of private claims, only the Pakistan deal followed this sequence. In the other cases (Ukraine, Russia, Ecuador, and possibly Nigeria in the future), the IMF program was followed by debt exchanges of private claims with PC rescheduling to follow next. This reverse sequencing complicates the application of the comparability principle and may create strategic incentives in the private sector to impose "reverse comparability" or to stake ex ante limits to the amount of private-sector burden sharing. This reverse sequencing also confirms why a case-by-case approach to PSI was followed: simple rules, even for the sequencing process (such as a debt exchange to follow PC rescheduling), appeared to be difficult to implement given the limited and very recent case history in debt restructurings.

The reasons for the reverse sequencing in these episodes are varied: in Russia creditors may have tried to lock in the amount of debt relief they were willing to provide before the PC imposed comparable terms. However, since conditions for Russia (oil prices, current account, fiscal situation) improved significantly after the private deal, the PC ended up offering a restructuring deal that did not imply any debt reduction, only generous restructuring. Thus, the private sector ended up complaining that they did it more than the PC in going first with its deal. In Ukraine, delays and suspensions in the IMF program that delayed a PC deal led investors to try to lock in the best deal they could in spite of the lack of a PC deal. In Ecuador, the PC deal was repeatedly delayed, given the time it took to negotiate an IMF program and, next, the country's inability to reach an agreement with its official bilateral creditors. Thus, in the summer of 2000 the country went ahead with its exchange offer in spite of the lack of a PC deal.

Ninth, differences among classes of creditors and conflicts of interests among them have to be addressed. Short-term investors (such as highly leveraged institutions, hedge funds, vulture funds, and other similar players) willing to buy distressed debt at low market prices have received hefty returns when, following exchange offers, the price of debt has rebounded. Longer-term investors, such as real money funds, asset management firms, and other investors with longer-term horizons, have at times disposed of their holdings of distressed emerging market debt when restructuring became likely and prices of such debt have plunged. Having short-term investors who bought low and who obtained significant capital gains made the chances of a successful exchange deal more likely in that such investors obtained significant mark-to-market gains. But the losses incurred by more dedicated and longer-horizon investors on their holdings of emerging 
market debt may reduce the core longer-term demand for this class of debt and lead to lower flows and higher spreads for this category of debt. ${ }^{51}$ In general, official policy has tried to avoid having a negative effect on the longer-term prospects for emerging market debt. These conflicts of interest among creditors are also one of the reasons why the model of creditors committees as a way to restructure debt may not work: such creditors may have very different interests and agendas, and the collective action problem of finding a common creditor position may be as difficult as the problem of negotiating with the debtor. ${ }^{52}$ Also, serious issues about whether Chinese walls are too leaky in a world where mark-to-market investors are buying and selling distressed debt may limit the possibility of having a representative creditor group; the actual composition of the holding group may change due to trading. Also, some investors may be actually shorting the distressed debt rather than holding significant long position in the asset.

Tenth, litigation risk has been, so far, limited. Acceleration and crossdefault occurred in the case of Ecuador, but no legal action was taken by creditors to enforce their rights. ${ }^{53}$ The usual limits to litigation were at work: it is costly, it takes a long time, and debtor assets are relatively hard to attach (even in cases, such as that of Nigeria, when the waiver of sovereign immunity is quite broad). Also, CACs have been successfully used - for example, in Ukraine - to bind in holdouts, cram down new terms on such dissenting minorities, and dilute their potential legal claims; even in cases, such as that of Ecuador, when the ex ante availability of CACs was quite limited, creative legal clauses such as exit consent clauses have been created to achieve the same result. Also, the generous terms of recent exchange offers, together with the sweetener of significant up-front cash, has effectively helped to bribe possible holdouts.

51. In this sense the interests of sell-side agents in financial firms that manage the restructuring of debt may be at odds with the interests of buy-side agents that manage dedicated emerging market portfolios for these firms. The impression that emerging market creditors' and buy-side interests are not fully represented is behind recent buy-side efforts to be involved in the PSI debate and the creation of the Emerging Markets Creditors Association.

52. Although in the 1980 s creditors found ways to solve this collective action problem, the situation today is somewhat different, for several reasons: syndicated loans provided a mechanism for the collective representation of creditors; explicit and implicit majority and sharing clauses were available in those loan contracts, whereas they are often absent in bond contracts; some financial institutions and individuals, namely Bill Rhodes of Citicorp, provided leadership to the group of creditors; the interests of the creditors were more homogeneous because they were all commercial banks, whereas in the case of bonds there is a wide range of creditors with very different interests. Thus, although coordinating creditors may not be impossible in the case of bonds, it appears to be harder than in the 1980s.

53. The recent Peru-Elliott case, in which a "vulture" creditor-Elliott Associates-successfully sued Peru and was able to get payment in full for its pre-Brady claims, may have changed the likelihood that creditors may successfully litigate in court sovereign debtor claims. However, how far-reaching this case will be is open to question because the legal issues were not tested in court, given Peru's decision to pay rather than end up in technical default before a court decision on the case. 
In the absence of exit consent clauses in the new bonds or clauses that allow ex post to bind in potential holdouts, the debtor has to decide how to deal with such holdouts. ${ }^{54} \mathrm{~A}$ credible threat not to provide holdouts with better terms than those of the exchange offer is the only way a debtor can ensure that the offer will be accepted; otherwise, many creditors would be better off waiting and trying their luck. Once the offer has been successfully accepted by the minimum threshold of the deal (a minimum 85 percent acceptance rate for the Ecuador case, for example), the debtor has to decide whether to keep its threat and risk litigation or to appease the holdouts and pay them on terms that will lead them to settle. The former solution is a way to ensure that the ex ante threat is not time inconsistent; otherwise, the game would unravel at the next debt-restructuring episode. However, buying off some marginal holdouts may, at times, be better for the debtor than engaging in costly and lengthy litigation.

The risks of litigation in future bonded restructuring cases should not, however, be underestimated. The recent Peru-Elliot case and the lessons learned by investors from previous restructuring cases may imply that creditors aggressively pursuing their claims may become more successful in the future.

\section{Concluding Remarks on PSI}

The official G7 and IMF PSI policy ("a case-by-case approach with principles, criteria, tools and guidelines") has been applied in the last few years to cases of bonded debt restructurings and cross-border bank lines (cases such as Korea, Thailand, Indonesia, Brazil, Pakistan, Ecuador, Ukraine and Turkey, and, indirectly, Russia and Argentina). The application of this policy has not led to the dire consequences and negative outcomes predicted by some a couple of years ago. Not only has the international capital market not been destroyed, but there is also little evidence so far that the flows of debt (and their pricing) to emerging market economies have been affected by this policy in ways that are jeopardizing long-term flows to such economies. Moreover, a combination of official money and case-specific PSI minimized the cost of crises in a number of large systemic countries and thus supported their rapid resumption of economic growth. Also, moral hazard distortions have been somewhat reduced, and there is evidence of healthy greater discrimination by creditors between better and worse sovereign debtors: average spreads do not seem to have been affected by the PSI policy, whereas the distribution of such spreads appears to be more reflective of underlying credit or repayment risk. Finally, the G7 PSI policy led to several cases of bonded debt restructuring that were successfully implemented even in the absence of an ex ante use of CACs. 
The official PSI framework - as described in the relevant G7 and IMF documents - provided a balance between the benefits of rules (to reduce the uncertainty and unpredictability of policy) and the advantages of discretion to deal with each individual and complex case study. The overall balance of principles, criteria, considerations, and tools in a PSI framework where a case-by-case approach has been shaped by basic principles and operational guidelines seems to have provided a trade-off between rules and discretion. Maybe, over time, case history will allow the development of clearer rules even if some degree of constructive ambiguity may remain as a component of an efficient PSI regime.

Many complex issues are still to be addressed in both the "liquidity" cases and the "insolvency" cases. They are difficult, complex, and not prone to simplistic answers and solutions. But the overall official PSI strategy in the 1990s ensured that the flows of capital to emerging markets continued to be the main source of finance to such countries while not being distorted by expectations of systematic bailouts of investors.

Such PSI policy may lead to endogenous financial engineering to create new classes of claims that are not as easily restructurable. In the 1990s, the emergence of interbank loans and bonded debt was partially-but only partially - the result of the bail-in of syndicated loans in the 1980s. Similarly, one can expect that new structured instruments embedded with complex derivative features may emerge as a strategy to avoid the bail-in of current debt instruments.

However, there are limits to how this PSI avoidance process can go. Eventually, a country's repayment of its debts depends more on its ability to pay than its willingness to pay because there are enforcement mechanisms (reputation and market discipline and punishment) to reduce the risk of opportunistic default. Thus, if a country will face a debt-servicing problem because of either an unsustainable debt burden or a profile of burden that is incompatible with short-term liquidity resources, some rollover, restructuring, rescheduling or, at the extreme, reduction of the debt payments will become unavoidable, however sophisticated the new instruments are. ${ }^{55}$ Such

55. When considering the issues of debt restructurings, one should be careful to distinguish between inability to pay and unwillingness to pay. As the theory of sovereign debt clearly suggests, the latter is an important issue. The latter phenomenon, that is, strategic defaults and opportunistic nonpayments, can be avoided via intertemporal and static market discipline. Punishments include trade sanctions, cutoffs from lending in international capital markets, and the output costs that creditors can inflict on defaulting sovereigns. Indeed, some punishment should be, and is, in the system to avoid strategic defaults. Some (e.g., Dooley 2000a), however, go so far as to argue that the rationale behind PSI policy and the IMF's lending into arrears policy is faulty because it will reduce the costs of strategic defaults. In Dooley's view, the output costs of default are the only meaningful punishment that prevents default in a world where the IMF or other agents cannot distinguish between nonpayment due to inability to pay and nonpayment due to unwillingness to pay. In his view, anything that reduces such debt renegotiation costs and makes it easier to restructure sovereign debt (such as CACs, IMF lending into arrears, or official sanctioning of defaults) will make the current system of international capi- 
instruments may shift the burden from some secured creditors to others (and the official sector is concerned that their result is not to shift the burden to the official sector), or they may just make the costs of renegotiating debt claims higher and thus make more difficult and more delayed such restructurings.

As long as the debt-servicing problems derive from true inability to pay or avoidable liquidity humps that lead to liquidity runs, a system that makes it very hard or costly to restructure debts may not be efficient and may impose severe costs not only on debtors but also on creditors. Creditors do not internalize the negative externalities or collective action effects of their unilateral attempts to stake seniority at the expense of other actors or the overall system. Thus, the official sector has been concerned about the development and widespread use of instruments that provide effective seniority to some private claims relative to other private claims or official claims or that make it harder to restructure debts.

\subsubsection{The Architecture to Reform the International Architecture}

Just as we began our discussion of crisis management with a survey of the institutional arrangements by which it is done, so we precede our discussion of more fundamental reform of the international financial architecture with a survey of the additional institutions and forums in which these issues have been discussed.

\section{Halifax Summit and Rey Report}

A broad debate on the steps needed to strengthen the international financial system was already under way when the Mexican peso was devalued in December 1994. The ensuing peso crisis gave the debate considerable impetus and pertinence. The annual summit of G7 nation leaders in 1995 held in Halifax, Nova Scotia, initiated work in a number of areas. They

tal flow more inefficient and will cause a reduction in the flows of capital to emerging markets. Dooley's basic point (that there must be costs to opportunistic default) is sensible, but the argument is taken to the extreme in ways that are not sensible. First, some countries will stop paying because of inability to pay; thus, in these cases it is in the interests of both the debtors and the creditors to renegotiate the debt contract and restructure, roll over, or reduce the debt. Making it very costly to do this restructuring will only hurt both creditors and debtors. Thus, a system in which the output punishment is as high as possible and the renegotiation costs are as high as possible is not efficient or optimal from a global welfare point of view. Second, in case of pure liquidity runs, there is a collective action problem that needs to be solved. Part of the solution (which is welfare beneficial to all) can be at times concerted rollovers of short-term debts that are coming to maturity. Thus, a system in which the costs of renegotiating debt claims and making reschedulings or rollovers are prohibitively high is also going to be welfare inferior to a system in which renegotiation is possible. Thus, a sound system is one in which the trade-off between the need to avoid strategic default (via punishments) and the need to renegotiate efficiently contracts when liquidity runs or insolvency requires it are balanced. A system in which the costs of renegotiation are too high is inefficient and of no benefit to either debtors or creditors. 
called for additional study of means to prevent future crises and to promote their orderly resolution when they do occur. The finance ministers and central bank governors of the G10 countries were asked to review ideas. The G10 group established a working party that submitted a report-informally known as the Rey Report, after its chairman - to the ministers and governors in May 1996.

The Rey Report noted recent changes that have altered the characteristics of currency and financial crises in emerging markets. It indicated that neither debtor countries nor their creditors should expect to be insulated from adverse financial consequences in the event of a crisis. It also called for better market-based procedures for the workout of debts when countries and firms are under financial distress. Specific reforms of bond contracts were proposed to encourage the cooperation and coordination of bondholders when the financial distress of a country or corporation requires the restructuring of the terms of a bond contract. It also suggested a review of IMF rules on lending into arrears in order to extend the scope of this IMF policy to include new forms of debt. Previously the power of the IMF had been used to support creditors' interests in the sense that it would cut off lending to any debtor that was not meeting its private debt service obligations. Lending into arrears would allow the IMF to continue lending, in certain circumstances, to countries that had temporarily suspended debt service payments but had continued to maintain a cooperative approach toward their private creditors and to comply with IMF adjustment policies.

A number of important innovations came out of this reform process: international standards for banking supervision, the so-called Basel core principles for banking supervision (Goldstein 1997); the development of international standards for making economic data publicly available, under the IMF's Special Data Dissemination Standard; an emergency financing mechanism in the IMF, the Supplemental Reserve Facility, to help members cope with sudden and disruptive loss of market confidence with financing significantly larger than traditional quotas; and the decision to expand the IMF's backup source of financing under the New Arrangements to Borrow. ${ }^{56}$

\section{G22 and Reports}

Despite some progress in strengthening the system, the eruption of the Asian crisis in 1997 demonstrated the need for further efforts. In November 1997, on the occasion of the Asia Pacific Economic Cooperation (APEC)

56. Twenty-five potential participants to the NAB agreed to make loans to the IMF when supplementary resources are needed to forestall or cope with an impairment of the international monetary system or to deal with an exceptional situation that poses a threat to the stability of the system. The twenty-five include many outside the traditional circle of member countries of the G10 or of the original General Arrangements to Borrow. 
Leaders Summit in Vancouver, a number of Asian leaders proposed a meeting of finance ministers and central bank governors to discuss the crisis and broader issues regarding the functioning of the international monetary system. They suggested that the meeting be global, that is, that it should include emerging market countries, and not just the usual small group of major industrialized countries. U.S. President Clinton responded by calling on Secretary Rubin and Chairman Greenspan to convene such a meeting. Finance ministers and central bank governors from twenty-two systemically significant countries (informally dubbed the G22) accordingly gathered in Washington on April 16 to explore ways to reform the international financial system that could help reduce the frequency and severity of crises. ${ }^{57}$ Ministers and governors created three working groups to consider measures to increase transparency and openness, potential reforms to strengthen domestic financial systems, and mechanisms to facilitate appropriate burden sharing between the official and private sectors in times of crisis.

The United States was strongly supportive of the creation of the G22 group, because it included systemically important emerging market economies, whereas other G7 members, especially the Europeans, remained slightly wary of a new group that might crowd out some functions traditionally performed by other groups or institutions in which they had more influence and leverage (the IMF executive board, the Interim Committee, the G10). The three working groups of the G22 presented their reports in October 1998, on the occasion of the annual meetings of the IMF and World Bank.

The report of the G22 working group on transparency and accountability recommended that national authorities publish timely, accurate, and comprehensive information on the external liabilities of private financial and corporate sectors as well as their own foreign exchange positions; it recommended adherence to existing international standards for transparency; it called for better monitoring of countries' compliance with such standards, including through IMF reporting on countries' adherence to internationally recognized standards. It also recommended that the potential for greater transparency of the positions of investment banks, hedge funds, and institutional investors should be examined. Finally, the IMF and other IFIs were called upon to be more open and transparent. Unnecessary secrecy was deemed particularly inappropriate in institutions telling others to be more transparent.

Because weaknesses in the financial sector were at the core of the Asian and global crisis of 1997-98, the report of the G22 working group on strengthening financial systems included the following recommendations:

57. The group ended up being effectively composed of twenty-six members, the usual size creep in these types of international groupings. 
strong prudential regulation and supervision of banks and other financial institutions; the design of explicit and effective deposit insurance schemes to protect bank depositors; the design and implementation of bankruptcy and foreclosure laws for insolvent firms; development of liquid and deep financial markets, especially markets in securities (bonds and equities); national implementation of the Basel core principles of banking supervision and of the objectives and principles of securities regulation set by the International Organization of Securities Commissions (IOSCO); coordination and cooperation among international organizations and international supervisory entities in strengthening financial systems; technical assistance for and training of government officials and regulators; improvement of corporate governance in both the financial and nonfinancial sectors, so that investment decisions respond to market signals rather than to personal relationships; implementation of efficient insolvency and debtor-creditor regimes that would facilitate workouts for corporations in financial distress. These may include procedures for systemic bank and corporate restructuring and debt workouts.

The report of the G22 working group on international financial crises identified policies that could help promote the orderly resolution of future crises, including both official assistance and policies and procedures that could facilitate appropriate PSI in crisis resolution. The work of this working group was a continuation of the development of official PSI policy that started with the Rey Report and continued in 1999 and 2000 with the development of the G7 framework for PSI (see section 3.1.2 for details).

At two subsequent meetings in March and April 1999, an enlarged group, the G33, discussed issues related to reform of the global economy and international financial system. The experience with the ad hoc G22 and G33 groups, which led to a broad dialogue on many important aspects of the international architecture reform, next led the United States to suggest in 1999 that a more permanent group, including advanced economies and systemically important emerging economies, the G20, be created.

The Road to the Koln and Kyushu-Okinawa Summits of the G7

The work of the G22 group laid the foundation for subsequent work on reforming the "international financial architecture" (a term first introduced by U.S. Treasury Secretary Rubin). The G7 took the main lead on this project, but emerging markets and other advanced economies were involved in the dialogue via the G22, G33, and G10 groupings.

In the fall of 1998, the Asian crisis became global with the collapse of Russia in August 1998, the contagious effects of this crisis to other emerging markets (Brazil and the rest of Latin America), the near collapse of LTCM, and the ensuing liquidity seizure in the capital markets of the United States and other advanced economies. By October 1998, the risk of a global financial meltdown had become significantly greater. The United 
States and the other $\mathrm{G} 7$ countries responded to this threat through a series of joint initiatives, outlined in the 30 October 1998 statement of the G7 finance ministers and central bank governors. The G7 committed to a number of reforms consistent with the recommendations of the G22 working groups as well as a great deal of additional work on architecture reform in areas previously not dealt with. At the same time, a series of uncoordinated reductions in interest rates in the fall of 1998 by the U.S. Federal Reserve, other G7 central banks, and a large number of other monetary authorities helped to restore liquidity in financial markets, reduce the panic that had enveloped financial markets following the Russia and LTCM episodes, and restore investors' confidence in the stability of the international financial system.

The $\mathrm{G} 7$ effort to reform the international financial architecture took momentum in the winter of 1998 and spring of 1999. The G7 agreed to come up with a specific architecture reform proposed by the time of the G7 Koln Summit in June 1998. This cooperative effort led to the report of the G7 finance ministers to the Koln Economic Summit ("Strengthening the International Financial Architecture"), where a broad range of proposals to strengthen crisis prevention and crisis resolution were agreed.

The G7 agreed to measures to strengthen and reform the IFIs (i.e., the IMF and MDBs), enhance transparency and the promoting of best practices (specifically, the strengthening of financial regulation in industrial countries), and strengthen macroeconomic policies and financial systems in emerging markets. The last measure included appropriate choice of exchange rate regimes for emerging markets, ways to improve their financial systems, ways to ensure that the benefits of international capital flows are maximized, and appropriate management of external and domestic debt to reduce liquidity and balance sheet risks.

The $\mathrm{G} 7$ also agreed on policies to improve crisis prevention and management. The latter included a formal framework for PSI in crisis resolution that became the core of the G7 PSI doctrine. This doctrine can be described as a "case-by-case" approach to PSI constrained by principles, considerations, and tools.

Following in part the private-sector demands for greater transparency, clarity, and rules and to provide clearer guidelines to the IMF, the case-bycase approach to PSI was refined in April 2000 through a set of "operational guidelines" providing more details on the process and substance of PSI. These operational guidelines were agreed by the $\mathrm{G} 7$ at the ministerial meeting around the IMF-World Bank spring meeting and were later formally adopted in the G7 finance ministers and central bank governors communiqué prepared for the July 2000 G7 summit.

The July 2000 Kyushu-Okinawa G7 Summit (preceded by the meeting of the G7 finance ministers at Fukuoka that produced the report on "Strengthening the International Financial Architecture" from G7 finance 
ministers to the heads of state and government) also saw the emergence of further G7 consensus on two other major issues-first, on how to reform the IMF and MDBs. The consensus on IMF reform at Fukuoka fleshed out the agreements previously reached by the G7 at the time of the IMF spring meetings in April 2000. Operationalization of the agreements on IMF reform (especially the reform of facilities approved by the IMF Board) was achieved by September 2000 in coincidence with the Fall Annual meetings of the IMF/World Bank in Prague (see section "Recent G7 Initiatives to Reform the International Monetary Fund" for details). Second, the G7 also agreed on policies towards HLIs (Highly Leveraged Institutions), Capital Flows, and OFCs (Offshore Financial Centers) that were supportive of the recommendations of the working groups of the Financial Stability Forum (see subsection below, "New Groups," for details).

\section{New Groups}

\section{The International Monetary and Financial Committee}

The International Monetary and Financial Committee (IMFC) came into being on 30 September 1999, when the IMF's board of governors approved a proposal of the IMF executive board to transform the Interim Committee into the IMFC and strengthening its role as the advisory committee of the board of governors; the committee usually meets twice a year.

The IMFC mandate and role are outlined by the IMF as follows:

Like the Interim Committee, the IMFC has the responsibility of advising, and reporting to, the board of governors on matters relating to the board of governors' functions in supervising the management and adaptation of the international monetary and financial system, including the continuing operation of the adjustment process, and in this connection reviewing developments in global liquidity and the transfer of resources to developing countries; considering proposals by the executive board to amend the Articles of Agreement; and dealing with disturbances that might threaten the system. ${ }^{58}$

The creation of the IMFC was the result of an elaborate diplomatic dialogue between the United States and Europe (especially France) regarding which international bodies to strengthen. The United States supported trying to involve more systemically important emerging markets in the dialogue on international financial issues that eventually led to the creation of the G20. The European nations, especially France, wanted instead to strengthen existing institutions and pushed for turning the IMF Interim

58. The committee, whose members are governors of the IMF, reflects the composition of the IMF's executive board: each member country that appoints, and each group that elects, an executive director, appoints a member of the committee, which, like the executive board, has twenty-four members. 
Committee into a stronger and permanent political body that would give guidance to the IMF board on major policy issues. The creation of the IMFC turned the longstanding previously "temporary" Interim Committee (IC) into a permanent one. However, the functions and roles of the IMFC effectively ended up being equivalent, with minor nuances, to those of the previous IC; certainly, the new IMFC, currently headed by U.K. Chancellor Gordon Brown, does not have the broad political mandate and power that the French wanted it to have.

\section{The G20}

The G20 was created at the urging of the United States, out of a desire for a forum where major emerging market economies would have a voice and participate in a dialogue on global financial issues. The positive experience with the G22 (and G33) process suggested a need to better involve these emerging markets.

The finance ministers of the G7 leading industrialized nations announced the creation of the G20 in September 1999. This new international forum of finance ministers and central bank governors represents nineteen countries, the EU, and the Bretton Woods Institutions (the IMF and the World Bank). ${ }^{59}$ The mandate of the G20 is to promote discussion and to study and review policy issues among industrialized countries and emerging markets with a view to promoting international financial stability. ${ }^{60}$

The first ministerial meeting of the G20 was held in Berlin in December 1999, and the second took place in Montreal in October 2000. So far, the G20 has been mostly a forum for dialogue (some belittlingly call it a "talk shop") on exchange rate regimes, national balance sheets management and prudent debt management, PSI and global financial issues, financial-sector regulation and supervision, and international codes and standards. Between ministerial meetings, the G20 work in 2000 continued at the deputies level with a broad dialogue and papers on three crucial issues in international financial architecture: exchange rate regimes, national balance sheets and vulnerabilities, and PSI in crisis resolution.

The October 2000 meeting of the G20 reviewed the global economic outlook, the challenges posed by globalization, and issues related to financial

59. Member countries include Argentina, Australia, Brazil, Canada, China, France, Germany, India, Indonesia, Italy, Japan, Mexico, Russia, Saudi Arabia, South Africa, South Korea, Turkey, the United Kingdom, the United States, and the European Union. The managing director of the IMF and the president of the World Bank, as well as the chairpersons of the International Monetary and Financial Committee and Development Committee of the IMF and World Bank, participate fully in the discussions. The first meeting was chaired by Minister Martin in Berlin in December 1999. The second meeting took place in Montreal in October 2000.

60. Finance Minister Paul Martin of Canada was selected to be the inaugural chairperson of the G20. 
crime and money laundering and discussed ways to make the world less vulnerable to financial crises, especially the issues discussed at the deputies level. The G20 finance ministers and central bank governors agreed on a series of measures aimed at "reducing vulnerability to financial crises" that included appropriate exchange rate regimes (supporting consistent and credible exchange rate regimes while not endorsing corner solutions to exchange rates), prudent liability management, PSI in crisis prevention and resolution (endorsing the principles and tools agreed by the IMF's IMFC at the 2000 spring and annual meetings), and implementation of international standards and codes.

In the view of some, the $\mathrm{G} 20$ should become over time an institution with greater importance and influence than the G7 because it is more representative of systemically important countries. Although over time the views of important emerging market economies might be more represented in international affairs, it is unlikely that in the short run the leadership role of the $\mathrm{G} 7$ will be reduced. However, the G20 is a forum where a serious dialogue between advanced economies and emerging markets can be pursued. ${ }^{61}$

\section{The Financial Stability Forum}

The Asian and global financial crisis suggested shortcomings to the pattern of national supervision and regulation of financial institutions in a world where such institutions operate globally and financial markets are becoming increasingly integrated. Although proposals for international financial regulation (such as Kaufman's global superregulator, discussed in section 3.1.6) are regarded as unrealistic, greater international coordination of policies of financial regulation and supervision has been deemed most useful and necessary. This need for coordination led to the creation in 1999 of the Financial Stability Forum (FSF).

In the winter of 1998, Bundesbank's President Tietmeyer worked on a proposal to establish an FSF to improve policy coordination among national financial authorities, the IFIs, and international regulatory bodies to promote international financial stability. Another aspect of the FSF is that its membership has been broadened beyond the $\mathrm{G} 7$ industrial countries and now includes eleven advanced economies (G7 plus Australia, Hong Kong, Singapore, and the Netherlands); additional emerging market economies (such as Malaysia) participate in the various working groups of the forum.

The FSF was first convened in April 1999, as its website notes, "to promote international financial stability through information exchange and international co-operation in financial supervision and surveillance. The Fo-

61. Some - for example, de Brouwer (2000) — go so far as to suggest that new international groups such as the G20 may replace or augment the policy function of the IMF. In this view, the IMF is too bureaucratic an organization and new international groups do not have the additional layer of interference in international policy making. These are, however, minority views. 
rum brings together on a regular basis national authorities responsible for financial stability in significant international financial centers, international financial institutions, sector-specific international groupings of regulators and supervisors, and committees of central bank experts. The FSF seeks to co-ordinate the efforts of these various bodies in order to promote international financial stability, improve the functioning of markets, and reduce systemic risk." The forum is chaired by Andrew Crockett, general manager of the BIS, in his personal capacity.

Initially, the FSF formed three working groups on capital flows, offshore financial centers, and highly leveraged institutions. They presented their reports and recommendations in the spring of 2000.

The working group on capital flows recommended that national authorities put in place a risk management framework, or national balance sheet, for monitoring and assessing the risks faced by their economies arising from large and volatile capital flows. The group, recognizing the vulnerabilities associated with sovereign debt that is too short term, recommended that the IMF and World Bank develop a set of guidelines for sound practices in sovereign debt and liquidity management, which they are now doing. The guidelines include, for example, addressing gaps in available statistics, encouraging greater transparency, and eliminating laws and regulations that inadvertently encourage imprudent behavior. The group also pointed to other important ways in which national authorities and international bodies should support the process of addressing the national balance sheet approach to assessing the risks from capital flows.

The working group on offshore financial centers (OFCs) concluded that it was essential for OFCs to implement international standards as soon as possible, especially in the areas of regulation and supervision, disclosure and information sharing, and anti-money laundering, and that such implementation would help address concerns about some OFCs. The group's recommendations spell out a process for assessing OFCs' adherence to international standards, identify standards for priority implementation and assessment, and propose a menu of incentives that could be applied to enhance their adherence to international standards. This led to the publication by the FSF in the summer of 2000 of a "blacklist" of twenty-five financial centers that have poor supervision and are not internationally cooperative. The decision to publish this list was based on the view that OFCs that are unable or unwilling to adhere to internationally accepted standards for supervision, cooperation, and information sharing create a potential systemic threat to global financial stability. The importance of the issue of OFCs was stressed by the G7 finance ministers' report at the Fukuoka Summit. The G7 and FSF consensus has put strong heat on these "deviant" jurisdictions to improve their supervision and be more cooperative.

The highly leveraged institution (HLI) working group considered issues of systemic risk and market dynamic in small and medium sized economies. 
Details on the progress in this HLI area are presented in the subsection "Highly Leveraged Institutions and Hedge Funds."

The FSF also began discussion of implementation of international standards to strengthen financial systems. The forum agreed that attention should focus on twelve key international standards, which will be highlighted in a compendium of standards. Also, a study group on deposit insurance made some progress and has asked the group to consult widely in the development of international guidance for deposit insurance arrangements.

In the future, it is likely that the FSF work will be less focused on policy recommendations and will be more of a "talk shop" about issues, providing discussion papers on matters of policy relevance. Also, the existence of the FSF has led to some healthy degree of competition, in addition to cooperation and dialogue, among international agencies such as the IMF and the Basel Committee on Banking Supervision. For example, the work by the FSF on the implementation of international codes and standards has led the IMF to renewed efforts to lead the way on these issues, as exemplified by its work on the Report on the Observance of Standards and Codes (ROSC).

\subsubsection{Reforms for Better Crisis Prevention}

Two of the most important pillars of the international financial architecture are exchange rate regimes (how flexible should they be?) and capital account regimes (how open should they be?). The attitudes of the G7 countries on these issues are important. Moreover, reform of the world monetary system that was fundamental enough to qualify as a "new architecture" or a "new Bretton Woods" would properly include these questions. However, these two topics fall inside the mandate of another of the chapters for this conference (Edwards, chap. 1 in this volume). In this part of our chapter, we look at other reforms to help prevent crises.

One of the central elements of architecture reform has been designing better policies for crisis prevention. Although crisis resolution is also central to the reform process, prevention is even more important to the extent that stronger policies and institutions can reduce the probability that financial crises will occur in the first place.

The efforts of the $\mathrm{G} 7$ and other international institutions and bodies to design policies for better crisis prevention have been comprehensive. Their broad scope includes a vast series of initiatives and actions:

1. Transparency and accountability of emerging markets, their economic agents, and the IFIs (such as the IMF), and greater disclosure and reporting by banks and other financial institutions in advanced economies

2. Greater attention given by the IMF and emerging markets to indicators of vulnerability to crises 
3. Greater attention to national balance sheet analysis and risk management, especially liquidity and balance sheet risks

4. Optimal public debt management to reduce liquidity risk, exchange rate risk, and balance sheet risk

5. Prudential regulation and supervision of financial systems in emerging markets

6. Policies to maximize the benefits of international capital flows

7. Work on highly leveraged institutions (including hedge funds)

8. Work on OFCs (see the subsection "New Groups")

9. Reform of the Basel capital adequacy standards

10. Private contingent credit lines

11. Implementation of international standards and codes

12. Better governance of the financial and corporate systems

It is not possible to discuss in great detail all the initiatives, programs, and actions in the above areas. Instead we will concentrate on some of the main issues and open questions.

\section{Transparency}

There has been a lot of support for greater transparency by emerging market economies and IFIs. The arguments are familiar: greater information, transparency, and openness on the part of emerging markets, IFIs and even advanced economies' institutions will allow private investors and the entire international financial community to better assess risks, reduce the chances of irrational rushes to the exits, and improve the efficiency of international capital markets. It is usually said that transparency is like motherhood and apple pie (i.e., everyone likes it) with the caveat that it may not be enough by itself to prevent crises.

Things are, however, more complicated. Resistance to greater transparency is still widespread among emerging market economies. For example, some resistance has been presented to the new SDDS (Special Data Dissemination Standard) reserve templates (i.e., the provision within the IMF's SDDS of much more detailed data about the foreign exchange reserves of member countries) and to the effort to expand the SDDS to external debt data disaggregated by economic sector, maturity, and currency composition. Many emerging markets still do not allow the publication of their IMF Article IV reports. Many countries still resist or have not gone through the ROSC exercise. The IMF reports on the state of the banking and financial systems of its member countries (the Financial System Stability Assessments) are still in the experimental stage, and many countries oppose their publication. The IMF effort to develop "macro financial prudential indicators" (which are indicators more of the health of the financial system than macro vulnerability) is somewhat stalled because many data on the financial-sector soundness are not available and there is some political 
resistance by emerging markets to such assessment. Progress on developing indicators of vulnerability to liquidity and currency risk is positive (as more country documents provide assessments and measures of such vulnerabilities) but still incomplete; regular publication by the IMF of vulnerabilities indicators for emerging markets may be a useful addition to this effort. Moreover, the February 2001 decision by the IMF to create a new international capital markets department will support - among other functions of this new department - the monitoring of vulnerabilities in emerging market economies.

Thus, although a lot of progress has been made in the area of transparency and the IMF has been quite open to the reforms in this area of crisis prevention, a lot of work still needs to be done. One issue that still remains somewhat sticky and is a matter of concern to IMF staff is whether greater transparency (such as, for example, publication of Article IV consultations reports) may lead emerging market officials to be less open, frank, and willing to share confidential information with IMF missions. Some have argued that the great emphasis on transparency has already had some chilling effect on IMF interactions with such officials. The issue is similar to the question of how much bank and financial regulators should disclose of the information they have access to on the health of financial institutions. On the one hand, good supervision and regulation requires, at times, discretion and withholding of some information. On the other hand, financial markets need as much information as possible to make rational assessment of the true valuations of firms and financial institutions. Thus, in general, more information and transparency may be useful, but there are limits to how far one could go in this area.

BIS Capital Adequacy Standards and

Their Implications for Crisis Prevention

Many issues in the reform of the Basel Capital Accord, which set guidelines for minimum capital levels to be maintained by countries' banks, are open. The initial draft of the consultative paper on how to reform the accord was issued in June 1999, and the comment period had closed by March 2000. Two of the major proposals in the initial consultative paper were to tie capital weights to ratings by credit rating agencies and to use banks' internal credit ratings as a basis for the capital weights.

The reform of the Capital Accord is a most complex issue with many dimensions. One question is the relative importance to be given to three pillars - market discipline, supervisory review, and capital regulation - in the capital adequacy framework. But some of the sticking points in the debate on this reform have an important bearing for the specific issue of international crisis prevention. First, if you allow some banks to use their internal models of risk, what criteria do you use to decide which banks, and in what countries, as opposed to requiring a more traditional standardized ap- 
proach? For example, Europeans believe that most of their banks should qualify to use internal models of risk, but some observers, especially in the United States, are skeptical that many European banks have the capacity to do so. Thus, it is important to set benchmarks on what institutions are going to be allowed to use such models.

Second, what is the best way to build compliance with international codes and standards into the capital adequacy ratios? The FSF and other official institutions (especially finance ministries) support this approach as a way to give incentives to emerging markets to implement such codes and standards. However, there is resistance on the part of bank regulators and the Basel Committee; in their view, bank capital charges should not be used as a tool to achieve goals not directly related to appropriate risk assessment. However, compliance with standards and codes does affect capital risk of financial institutions. Also, there is some concern that bank regulators look at the issue of the capital standards in too narrow terms (the risk of individual banks) and do not appreciate enough the importance of systemic risk. Incentives to implement codes and standards may reduce financial contagion, the risk of systemic banking crises, and the likelihood of systemic risk to the international financial system.

The Basel Committee issued a new draft of the consultative paper in January 2001, seeking comments from interested parties by May 2001. The initial draft proposal to link banks' capital to ratings produced by external credit rating agencies was dropped in the new draft. Also, although the January 2001 draft reaffirmed the support for internal risk models, concerns have been expressed that reliance on internal ratings may aggravate economic cycles, because loan standards may be relaxed during economic booms and tightened during recessions.

\section{Highly Leveraged Institutions and Hedge Funds}

Concerns about the role of HLIs, and hedge funds in particular, emerged in the wake of the Asian crisis for two reasons. First, the collapse of a large hedge fund, LTCM, provides a vivid example of how high leverage contributes to systemic risk. Second, actions of some hedge funds in small and medium-sized economies led to concerns about the aggressive trade practices of such funds and to allegations of market manipulation. Hong Kong and Australia, in particular, argued that hedge funds had engaged in manipulative practices in their foreign exchange and other asset markets. Accordingly, one of the three initial working groups of the FSF, set up in the spring of 1999, addressed the question of the role of HLIs in systemic risk and market dynamics in small and medium-sized economies.

Regarding the issue of systemic risk, the recommendations of the report of this working group resemble, with some differences, the eight recommendations of the report of the U.S. President's Working Group on Capital Markets (April 1999). It was agreed to emphasize indirect regulation of 
hedge funds, for the time being, and to avoid direct regulation. ${ }^{62}$ The recommendations included measures aimed at better risk management by HLIs and their counterparties (better credit assessments, better exposure measurement, establishment of credit limits, collateral management techniques), better creditor oversight (greater intensity on firms that are falling short, periodic reaffirmation of compliance with sound practices), and enhanced public disclosure and reporting to authorities.

Regarding market dynamics, the HLI working group ${ }^{63}$ formed a subgroup that performed a study of the role of HLIs (both hedge funds and proprietary desks) in the currency turmoil experienced by six economies (Hong Kong, Australia, New Zealand, South Africa, Singapore, and Malaysia) during 1998. The results of this study ${ }^{64}$ were somewhat different from those of the IMF study on the role of hedge funds in the currency turmoil in East Asia in 1997. The latter considered the role of hedge funds only in the initial stages of the crisis (up to November 1997), whereas the FSF's HLI market dynamics study group considered the continuing turmoil in the six small and medium-sized economies under study during 1998. Whereas the IMF study had come to the conclusion that hedge funds had played only a minor role (being at the back of the herding pack in 1997 rather than as the leaders of it), the HLI study group found a more significant role of hedge funds and proprietary desks (which trade for their own account) of international financial firms in the latter episodes of turmoil in 1998 in the six economies studied. For example, circumstantial evidence was found of some aggressive trade practices (rumors, false information, and placing large trades at less liquid times of the day, such as lunch). ${ }^{65}$

Although it was hard to reach a consensus on controversial issues of market destabilization and manipulation, the group concluded that

- From time to time, HLIs may establish large and concentrated positions in small and medium-sized markets. When this is the case, HLIs have the potential to influence market dynamics, especially in periods of market turmoil.

- The judgment as to whether HLI positions are destabilizing has to be made on a case-by-case basis. Some members of the group took the position that the largest hedge funds exacerbated the macroeconomic difficulties of several economies in 1998 and even manipulated their

62. Options other than indirect regulation, such as a credit register and direct regulation, although rejected for the time being, will be reconsidered by the FSF if implementation of the other recommendations proves ineffective.

63. The HLI group included officials from finance ministries, central banks, and financial regulatory agencies of major industrial countries and some emerging market economies.

64. The report of this group ("Report of the Market Dynamics Study Group") can be found at [http://www.fsforum.org/Reports/RepHLI.html].

65 . For a recent theoretical and empirical study of the role of large players in currency crises, see Corsetti, Pesenti, and Roubini (2001). 
currencies, whereas others believe that, provided the economic fundamentals are strong, hedge funds are unlikely to present a threat.

The HLI report made a series of recommendations to address the issue of market dynamics even though most of its policy recommendations were in the area of systemic risk. First, the report noted that enhanced risk management practices could also address some of the concerns raised by emerging markets by constraining excessive leverage. Second, the HLI group also noted that where trading takes place on organized exchanges, requiring market participants to report to regulators, and possibly requiring position limits as well, could alleviate some of the pressures caused by large and concentrated positions. Third, the FSF recommended that market participants themselves articulate guidelines for market conduct in the area of foreign exchange trading. These market guidelines would address the concerns of smaller and medium-sized economies about the aggressive trading practices that might have contributed to exacerbating market pressures in period of market turmoil.

Progress in implementing the President's Working Group recommendations, and those of the HLI working group, has been slow, because they require both regulatory and legislative actions that have been hard to achieve. Some who had favored the idea of direct regulation but accepted the indirect regulation approach (hoping for a rapid implementation of the recommendations) feel frustrated that more rapid progress has not been made in implementing measures to reduce the risks posed by hedge funds and other HLIs; several of the eight recommendations of the President's Working Group remain to be implemented.

However, the nature of the hedge fund industry has changed rapidly, with some significant deleveraging occurring over time. Some major hedge fund players have effectively closed shop, especially those (LTCM, the Tiger funds, the Soros funds) that were alleged to be behind the episodes of systemic risk and destabilizing market dynamics. Emphasis on the role of hedge funds may be now misplaced in that they do not play the same leading role that they did a few years ago. The size of the assets managed by hedge funds is small (less than $\$ 1$ trillion), even after controlling for leverage, relative to that of the mutual fund or insurance sectors, each of which manages more than $\$ 5$ trillion of assets. Although such players are regulated and may be less leveraged than other players, they command large financial resources, and their investment decisions can significantly affect currencies and asset prices. Thus, such new players may emerge as more relevant for future systemic crises and the efforts to avoid them. Moreover, recent evidence about reduced liquidity in financial markets (the forex market and other G7 financial markets) and the concerns expressed about them may have to do with the disappearance of large leveraged players in these markets. As some financial institutions have closed — or scaled down the ac- 
tivities of - their proprietary desks, and as some large macro hedge funds have closed shop or significantly reduced the size of their positions, capital and liquidity available for market-making and contrarian positions may have fallen, thus leading to reduced liquidity and greater asset price volatility.

\section{Private Contingent Credit Lines}

Another possible tool for emerging market countries to prevent crises is facilities for CCLs from private international banks. These could take two forms, either the contingent repo facilities that Argentina has or loan facilities secured with collateral as suggested by Feldstein (1999b). The issue of collateralized facilities relates to the question of credit enhancements, an issue discussed later in the "Collateral and Credit Enhancements" section. Private CCLs, like those of Argentina, were also set up in Mexico and Indonesia. Although private CCLs may become an element of the toolkit for crisis prevention, one could be somewhat skeptical of their overall effectiveness for a number of reasons:

1. It is not obvious whether these facilities provide additional financing resources to an emerging market economy in periods of pressure and turmoil. The creditors may want to reduce risk when such pressures emerge and can always reduce their exposure to the debtor in a number of ways, either through direct reduction of other long positions in the country or through the use of financial derivatives to hedge the country risk and exposure.

2. The experience with private CCLs has so far been disappointing. They were unable to stem the crisis in Indonesia and were not even used, probably because of their small size relative to the amount of capital flight.

3. Mexico drew on its facility in 1999 when the global turmoil spread to its economy. Because the borrowing rate was well below the higher spreads on Mexican debt, however, Mexico's bank creditors were upset about what they perceived to be an inappropriate use of a cheap facility in periods of pressure. This peculiar attitude of creditors (reluctance to provide the insurance agreed upon on low terms in good times when hard times come) shows that the reality of private CCLs is partially at odds with how they are supposed to work in principle. However, there may be more efficient ways to design private CCLs, such as setting them with a spread relative to LIBOR rather than with a fixed interest rate and thus reducing the incentives of the borrower to capture an arbitrage gain in periods of pressure.

Thus, private CCLs have been so far a mixed bag. There are significant doubts about their true effectiveness as a crisis prevention tool.

\section{Vulnerability Indicators}

Emphasis has been given to national balance sheet management at both the aggregate and sectoral (government, financial sector, and corporate sec- 
tor) levels and the importance of managing liquidity and balance sheet risk. One aspect is the development of better indicators of vulnerability to risk of crisis. Although early warning systems may be a component of this better monitoring of risks, this task is best left to the private sector and academic research.

There is some consensus that the IMF should not be in the business of providing to the markets estimates of the probability of currency and financial crises; it should instead provide the data and indicators (various measures of financial and debt ratios) that allow private investors to make their own assessment of such risks. In fact, having the IMF issue "yellow cards" or "red flags" in the form of specific quantitative assessments of the risk of a crisis would be dangerous. It would be subject to Type I and Type II errors (failing to predict a crisis that then occurs, or predicting one that does not materialize - or, worse, triggering one that would not have otherwise occurred). However, the development of better data and indicators of external vulnerability is an essential public good that the IMF should be able to provide to markets. One problem during the Asian crisis was confusion and lack of data even on basic measures of external debt. The recent agreement by the IMF members to extend the SDDS to external debt data (ideally disaggregated by currency, maturity, sectoral breakdown, and residency of the holder of the claim) will go a long way in the direction of better information about exposure and will be a good basis for the development of more sophisticated indicators of vulnerability.

\subsubsection{Policy Regarding Reform of the International Monetary Fund}

Because the large industrialized countries dominate the IMF, any discussion of their policies must consider their attitudes toward reform of the IMF. There is no shortage of suggestions to the effect that reform is needed. ${ }^{66}$

\section{The Nature of International Monetary Fund Critiques}

Let us consider some of the arguments that have been made in the debate over reform of the IMF. ${ }^{67}$ We will not elaborate in detail on each one or try to make a judgment among them; that is the task of other chapters in this conference volume. The arguments are of interest here as inputs to the U.S. and $\mathrm{G} 7$ positions on reform of the IMF.

Most evaluations begin with a sentence along the lines of, "The IMF has made serious mistakes - what better evidence than the severity of the 199799 crises in emerging markets?" But what comes next? Sometimes the crit-

66. Reviews include Krueger (1997). We do not have space here to consider in detail the World Bank and other MDBs.

67. Many of the critiques, and a few defenses, are collected in McQuillan and Montgomery (1999). 
ics go into sufficient detail to specify exactly what they think it is that the IMF has been doing wrong and what sort of reforms are necessary. Here are some of the most frequently suggested reforms.

1. The IMF should encourage more exchange rate flexibility. Reluctance to abandon currency targets and to devalue in the face of balance-ofpayments disequilibria led to the crises of 1994-99.

2. The IMF should encourage more exchange rate stability, including firm institutional commitments such as currency boards or dollarization that will restore monetary credibility, rather than government manipulation of the exchange rate to gain competitive advantage at the expense of people's living standards.

3. The international community needs to make more official resources available for emergency programs, bailouts, debt forgiveness, and new loans. There was no good reason based in economic fundamentals for the East Asians to suffer the sudden reversal of capital inflows in 1997; under such circumstances it is the role of the IMF to plug the gap and restore confidence with large official packages of financial support. Thus, the IMF should become a quasi-international lender of last resort.

4. We need to address the moral hazard problem more seriously, because it is the ultimate source of the crises. Investors and borrowers alike are reckless when they know they will be bailed out by the IMF and G7. Thus, big bailout packages should be avoided, and whenever there is a run-off (no rollover) on private claims, semicoercive forms of burden sharing, such as concerted rollovers, standstills, and capital controls, should be introduced to bail in the private sector.

5. Countries need to adopt capital controls to insulate themselves from the vagaries of fickle international investors.

6. Countries need financial openness and capital account liberalization so they can take advantage of international capital markets (e.g., to finance investment more cheaply than from domestic savings and to provide some discipline on domestic policies).

7. Country programs need easier monetary and fiscal targets; recent IMF programs have had too much macroeconomic conditionality, inflicting needless recessions.

8. Country programs need tighter macroeconomic discipline, since monetary and fiscal profligacy is the source of most balance-of-payments problems, and private investors cannot be persuaded to keep their money invested in the countries without sound macro policies that restore investors' confidence during a crisis.

9. The IMF needs to customize conditionality to individual countries' circumstances. East Asia did not have the macro problems so familiar from Latin America. 
10. The IMF needs to require standardized and strict rules-based precertification in order for a country to qualify for IMF assistance.

11. The IMF, along with the World Bank, should pay more attention to the needs of poor countries, rather than those that are successfully developing and able to attract private capital, and should place more emphasis on poverty reduction in each country program.

12. The IMF should remove any subsidy component in loans and charge higher interest rates, close to private market rates. In any case, it should leave poverty reduction to the World Bank.

One could continue, but the point is clear. Some want more exchange rate flexibility; some want less. Some want more macroeconomic austerity and conditionality; some want less. Some want more bailouts, some less. Some want more capital controls, some less. Each odd-numbered point above contradicts each corresponding even-numbered point. But one cannot have both more and less exchange flexibility, both larger and smaller bailouts, both more open and more closed financial markets, both looser and tighter macro policies, both more and less customization of conditionality.

The principle is thus that "for every critique of the IMF there exists an equally forceful critique that is the diametric opposite." This of course does not refute the fact that some number of these attacks could be justified: it does not let the IMF off the hook. Each argument should be considered on its merits. The point, however, is that most of the public debate is conducted at a level of sufficient generality that critics can give the impression of sharing a common viewpoint when they actually have contradictory points in mind. This can give politicians the very misleading illusion that reforms are straightforward to determine and easy to implement.

Critics on the right can give politicians the impression that the desirable reform is a simple matter of reining in the excessive interventionism of the G7 and IMF. They conclude that all unbiased analysts agree that it is sufficient to let the private market work on its own, to refrain from bailouts. The danger is that when such politicians get into office, they will soon discover a need to rescue important and sensitive countries, as their predecessors have done, after having made a point of saying explicitly that they would not.

Critics on the left make a strong case when they argue that the United States and other rich countries are currently devoting a very small level of resources to attempts to help poor countries. ${ }^{68}$ However, the political obstacle to greater U.S. support for multilateral institutions is the perception that most such funds have in the past not been well spent. This perception

68. For reasons of space, we do not cover in this paper important questions regarding how to deal with poverty, what developmental policy should be, and the status of the HIPC initiative to reduce the debt burden of the poorest developing countries. 
has some basis in reality: some international agencies have been inefficient in the past. However, the IMF has been one of the more efficient and costeffective multilateral institutions. ${ }^{69}$ The danger is that the critics will succeed in tearing down the IMF and then be disappointed when no new and improved institution is substituted in its place.

\section{The Meltzer Commission Report}

Although proposals for the reform, and even abolition, of the IMF abound (see, e.g., De Gregorio et al. 1999; Feldstein 1999a; Meltzer 1998; Schultz, Simon, and Wriston 1998; Calomiris 1998a), some have had a particularly political high profile. Specifically, the recommendations of the Meltzer Commission - formally the International Financial Institution Advisory Commission created by the U.S. Congress in 1999 to provide suggestions for reform of the IMF and MDBs - have received the most attention. Some of the recommendations of the commission subsume, in one form or another, other proposals for IMF reform. Thus, consideration of the commission recommendations provides an opportunity to analyze a number of other suggestions for the reform of the IFIs and the international architecture (the role of ex ante and ex post conditionality, the need for an international lender of last resort, the use of collateral in IMF loans, market discipline, and the opening up of emerging economies to foreign financial institutions).

The main recommendations of the commission, presented in its report, were as follows: ${ }^{70}$

1. The IMF should become a quasi-international lender of last resort that provides large-scale, essentially unconditional support only to prequalifying countries that are sound in their financial system and fiscal affairs (ex ante conditionality) but that suffer from international contagion nonetheless.

2. The IMF should avoid ex post conditionality and lending to countries in crisis that lack sound economies or policies and thus do not prequalify. It should provide only "counsel" and "advice," no loans or support, to such economies. This would effectively terminate existing lending programs, such as Stand-By Arrangements (SBAs), of the IMF (and MDBs) in a wide range of emerging market economies.

69. One would think it would be easier to explain to the public the merits of an organization that has nothing to do with foreign aid but, rather, lends money in time of crisis, in return for countries' commitments to needed reforms, and is almost always repaid.

70. International Financial Institution Advisory Commission (2000). The commission also made recommendations about MDB reform, such as taking the World Bank out of the development finance business and relying mostly on grants for World Bank support. We will not discuss here, given space limits, reform of the World Bank and other MDBs. We briefly touch upon these issues, especially the division of labor between IMF and World Bank, in the later section "Mission Creep." 
3. IMF loans to prequalifiers should be short-term (a term of four to eight months was mentioned), set rising penalty interest rates to encourage early repayment, and rely on security by means of a clear priority claim on the borrower's assets.

4. Conditions for prequalification by IMF borrowers include the following: (a) a sound banking system, including the opening of emerging markets' financial systems to foreign banks; (b) regular and timely publication of the maturity structure of a country's outstanding sovereign and guaranteed debt and off-balance sheet liabilities; (c) adequate capitalization of commercial banks either by a significant equity position, in accord with international standards, or by subordinated debt held by nongovernmental and unaffiliated entities; (d) establishment by the IMF of a proper fiscal requirement to assure that IMF resources would not be used to sustain irresponsible budget policies.

To understand the main differences between the current structure of the IMF and that proposed by the commission, one may think as the current IMF structure as being based on four pillars, each requiring some degree of ex ante or ex post conditionality. The commission instead effectively recommends an IMF with only one pillar that relies strictly on ex ante conditionality. ${ }^{71}$ Let us consider briefly each of the four pillars.

First is a new CCL facility that is similar in some aspects to the one proposed by the commission in that it relies on prequalification criteria (sound financial and fiscal and data transparency) and stresses ex ante conditionality (prequalifiers would have access with little ex post conditionality to relatively large IMF resources in case of contagion).

Second are regular conditionality-based loans (Stand-By Arrangements) for countries that are small and nonsystemic and have serious macro and financial problems and that therefore do not prequalify for large support. The idea of this pillar is that program conditionality provides the sticks to ensure reform while access to normal quota IMF resources provides financial support for policy adjustment by the country in difficulty. The majority of IMF programs - currently and historically - have been of this type, for countries that do make mistakes and do have crises but who would not prequalify under the stringent conditions of the first pillar, given macro and financial or structural shortcomings.

Third, the current system allows exceptional financing (i.e., financing in excess of normal quotas) to countries that would not prequalify for a CCL because of their policy imperfections but that are deemed to be systemically important and to require large amounts of support to adjust to severe crises, thereby preventing contagious effects on other emerging markets. These ex-

71. The commission would also accept the exceptional and transitory use (before the switch to the new long-run regime) of a pillar of large financing for systemically important countries that are in crisis and do not prequalify for the large unconditional financing. 
ceptional funding arrangements are the recently created Supplemental Reserve Facility (SRF) or other arrangements that provide loans in significant excess of normal quotas. The SRF was used in recent large support packages for the first time in Korea in 1997, and then in Brazil, Argentina, and Turkey. The commission's view is that this third pillar should be phased out over time. However, the commission added an escape clause that would allow-in a transition period to this new long-run regime-for IMF large lending in exceptional cases in which significant contagion may occur.

Fourth, the last pillar of the current IMF system is the existence of subsidized lending facilities to very poor countries (the Extended Structural Adjustment Facility and now the Poverty Reduction and Growth Facility) and multiyear lending at slow repayment rates to countries with serious structural problems or in transition to a market economy (the Extended Fund Facility [EFF]). The commission argued instead that the IMF should cease lending to countries for long-term development assistance (eliminate ESAF and PRGF while writing off all debt to HIPC countries) and for longterm structural transformation (as in the post-Communist transition economies, i.e., elimination of the EFF). Such functions should instead be moved to the World Bank and other MBDs.

The commission's report argues that IMF packages, especially the large loans to countries having serious problems, exacerbate both creditor and debtor moral hazard; that ex post conditionality is not effective and may even be harmful; and that a sensible long-run regime is one in which crises are prevented in the first place. It urges that a system of inducements (IMF support to sound economies) and sticks (no IMF support to unsound economies) will provide the right strong incentives for countries to implement reforms that will prevent crises from occurring in the first place. In addition, the commission recommends that lending to poor countries and to countries that have structural problems or are in transition should not be the business of the IMF, which should concentrate on avoiding panics, runs, and crises in sound economies that are subject to contagion. The World Bank and MDBs should instead deal with the structural and macro problems of these poor and transition economies.

The publication of the commission report led to a public debate on its recommendations. Critics included minority members of the commission, the U.S. Treasury Department, and others (see Bergsten 2000; Levinson 2000; and U.S. Treasury 2000). We will here summarize some of these critiques and relate them to the arguments made by the commission.

Consider first the CCL. With the recent changes made to this facility, it is similar in some ways to that suggested by the commission: countries would prequalify based on macro and structural criteria, and exceptional financing would be quickly available for them. Although this facility may play a role in the new international financial system, critics (for example, U.S. Treasury 2000) believe that one should not overestimate its importance 
or place it at the center of a reformed IMF. For one thing, no country has applied (or qualified) for this facility yet, even after the reform of the facility. (Members of the commission would argue that this is because the countries believe that if necessary they will be bailed out on more attractive terms.) Second, while it is possible that very sound economies may be subject to contagion from time to time, the likelihood of this happening may be limited. The history of banking crises suggests that sound banks rarely experience runs and bank runs are almost always triggered by poor financial conditions and policies of particular banks: poor lending, little capitalization, high and growing nonperforming loans, and so on. For the same reason, the possibility that contagion would lead to a run on a very sound country is relatively small: Even if a country qualified for the CCL (or the similar facility proposed by the commission), chances are that this facility would rarely be needed and used. If the above argument is correct, a CCL type of facility could not be the central element of a system of crisis resolution: its importance would, in practice, be limited to preventing occasional extreme episodes of contagion to otherwise sound countries.

Is there a role for the third pillar of the current system, exceptional financing for crisis countries that do not prequalify for the CCL? Critics (again, U.S. Treasury 2000) argue that the commission recommendationsif narrowly interpreted - would have disallowed financial support to most of the large and systemic economies enveloped in the financial crises of the 1990s (Mexico, Thailand, Indonesia, Korea, Brazil, Russia, Argentina, and Turkey). They probably would not have prequalified for IMF support given macro weaknesses (poor fiscal positions in Mexico, Brazil, Russia, Argentina, and Turkey) or structural policy weaknesses (weak financial sectors in Mexico, Thailand, Indonesia, Korea, Russia, and Turkey). The third pillar of the current system, the SRF or other facilities allowing exceptional financing, was used in all these cases. The commission would allow an escape clause in limited, transitory, and exceptional circumstances in which systemic problems are at stake and exceptional financing would be allowed. However, a generous interpretation of this caveat would still imply that most of these large-scale packages would not have occurred in a new regime in which the IMF had been reformed along the lines of the commission recommendations.

To understand the logic of the commission's views, one should note that the commission sees its suggested reforms as leading, over time, to a world where countries "get their act together" in the knowledge that large-scale support would not be available unless the economy is sound. Thus, the commission is aiming at creating a long-run regime in which large-scale packages would not be made available to countries with unsound financial and fiscal policies. Also, according to the commission, the recommendations would be phased in over a period of five years, thus allowing countries the time to adjust their policies to this new regime of "no bailouts or support 
unless sound." Still, in the new long-run regime, countries that are systemically important but fail to adhere fully to the sound economy criteria for unconditional support would not receive financial support.

The commission supporters rebut that, in the new long-run regime of a reformed IMF, countries would know that failure to satisfy the criteria for CCL-type support would lead to no support at all and that this would provide a large incentive to clean up the economy and the financial system and thus prevent the kind of crises that afflicted these economies. However, supporters of the current system, in which exceptional SRF-style support for countries that do not otherwise prequalify for a CCL facility is maintained even in the long run, make various arguments: these crises may have systemic effects, and thus the international community has to deal with them even if they were partly caused by poor policies. Although poor policies and weak financial systems may trigger a crisis, the case of Asia suggests that an element of panic and self-fulfilling runs prevails even in cases in which fundamentals were not fully sound. Thus, allowing large support to systemically important economies in exchange for a serious program of reform constrained by tight conditionality may be beneficial to the country and its creditors and help maintain the stability of the international financial system. Indeed, in cases such as those of Mexico, Korea, Thailand, and Brazil, this exceptional support to countries that would have not prequalified for a CCL allowed macro and structural reform that benefited all relevant parties.

The terms of the commission recommendation for large-scale unconditional support to prequalifiers were inspired by - and founded on - the Bagehot principles for lender-of-last-resort (LOLR) support. Nevertheless, they have also been debated and criticized by some commentators.

First, the implied scale of the support seems to be extremely large given the resources available to the IMF: the commission suggested that such support might be as large as one year of a country's government revenues. Based on current data, U.S. Treasury (2000) argued that this would have implied lending to Brazil equal to $\$ 139$ billion. This is far in excess not only of the country's quota in the IMF ( $\$ 4.5$ billion) but even of the size of the recent IMF program ( $\$ 14.5$ billion). In this view, such large packages would be well beyond the financing capacity of the IMF and would increase the moral hazard involved.

The second controversy regards the commission's support for securing IFI loans by means of a clear priority claim on the borrower's assets. There are two substantial issues with this proposal.

1. In practice, IFIs already have quasi-preferred creditor status. Therefore, the extra gain may be small. If it is contemplated to use resources of the government as outright collateral for IFI lending, this may worsen the creditworthiness of the country in the eyes of the private sector. 
2. The historical practice of LOLR has been very different from the Bagehot principles that the commission cites. Recent studies show that little real hard collateral has historically been used in LOLR lending. ${ }^{72}$

Third, regarding the idea of lending at penalty rates, note first that, as suggested by Giannini (1999), the Bagehotian principle calling for "lending at a penalty rate" and lending to "solvent but temporarily illiquid banks" has not been usually applied in historical cases of banking crises. Moreover, based on data from recent historical crises showing large and protracted spikes in sovereign spreads after a crisis, U.S. Treasury (2000) argued that lending at penalty rates would "entail in most cases interest rates so high that these loans would worsen the underlying financial position of the borrowing country." Thus, although penalty rates may make some sense-and, indeed, the SRF comes with penalty rates that are 3 percentage points above short-term riskless market rates-systematic use of market rates on a country's debt would imply very high, and possibly unsustainable, borrowing rates. Also, given the seniority of IMF lending (which would be even stronger one if collateral is used), it does not make sense to use market rates that reflect default probabilities on less senior debt.

Fourth, the short-term maturity of the loans recommended by the commission would have forced repayment prematurely relative to what was needed by these economies in crisis. (The report mentioned four months, with only one further four-month extension. $)^{73}$ Even in successful largescale IMF programs (Mexico, Korea, Thailand, Brazil), actual repayment lasted more than eight months. In this regard, note that even the short-term SRF facility allows at least two years for repayment. Given the spikes in sovereign spreads occurring after crises or the effective cutoff of a country from access to international capital markets, excessively short repayment periods may end up being destabilizing.

The commission would also eliminate altogether the second pillar of the current system. It would eliminate all lending to countries that experience a crisis because of their own policy shortcomings and that thus do not prequalify for support. They will have to adjust on their own without any IMF conditional support. These cases, regular SBAs to countries in macro and financial difficulties, represent the bulk of the program activities of the IMF. Thus, the commission would drastically reduce the number of countries and cases for which access to IMF lending is allowed. The IMF would provide only "counsel," not funding, to countries with complex and deepseated problems. This recommendation is based on several arguments.

72. Giannini (2000). Charles Calomiris tells us that the commission support for this type of security is not support for collateral. Members of the commission do not necessarily agree with the language we use to characterize their positions, in general.

73. In congressional testimony, however, one of the commission members-Calomirissuggested a more flexible interpretation of the maximum maturity of these loans. 
First, the argument against funding with only ex post conditionality is the moral hazard argument. Countries believe that the IMF will rescue them if a crisis occurs. Hence they have less of an incentive to strengthen their financial systems until it is demanded by the fund. If strengthening their financial system were instead made a precondition for receiving IMF credit, the argument goes, weaker countries would rush to adopt reforms that would secure their access to IMF resources. Ex ante conditionality is therefore believed by some to be more useful in limiting the incidence of crises or limiting the scope and duration of crises that do occur. Second, the commission argues that ex post IMF conditionality is ineffective in practice, judging by historical experience.

Critics (U.S. Treasury 2000) of the proposal to eliminate standard ex post conditionality lending programs make several arguments. First, they argue that IMF conditionality works both in theory and empirically. Conditionality works in theory because the IMF would not have much of an impact if it could provide only counsel to countries with complex and deep-seated problems. The same is true if it lent to countries without any desire or commitment to change. Leverage comes from money, because the carrot of financial support is an incentive for policy adjustment and reform. These countries often need the catalytic financial support of the IMF, which, in addition to conditionality and commitment to policy stabilization and reform, is crucial to restoring investors' confidence. In recent financial crisis episodes, IMF involvement and ex post conditionality made the key difference, providing incentives for policy adjustment that was eventually successful in restoring economic growth.

Critics also argue that, empirically, IMF conditionality is more effective than argued by the commission. Indeed, there is a broad empirical literature on the effectiveness of conditional IMF lending. Most studies have instead relied on large cross-country samples that allow for the application of standard statistical techniques to test for program effectiveness, avoiding the difficulties associated with trying to generalize from the finding of a few case studies. The overall conclusion of such studies is that IMF programs and IMF conditionality have on balance a positive impact on key measures of economic performance. Such assessments show that IMF programs result in improvements in the current account balance and the overall balance of payments. This result is robust across a range of different methodologies. Haque and Khan (1999) provide a recent survey. ${ }^{74}$

The impact of IMF programs on growth and inflation is less clear. The first round of studies failed to find any improvement in these variables. More recent studies suggest that IMF programs result in lower inflation,

74. Kenen $(2001,53)$ criticizes the commission report for a selective quoting of Haque and Khan. 
but these studies do not consistently establish that this result is statistically significant. ${ }^{75}$ The impact of IMF programs on growth is more ambiguous. Results on short-run growth are mixed; some recent studies found that implementation of IMF programs led to an immediate improvement in growth (Dicks-Mireaux, Mecagni, and Schadler 1997), whereas other studies (Bordo and Schwartz 2000) found a negative short-run effect. ${ }^{76}$ Studies that look at a longer time horizon, however, tend to show a revival of growth (Conway 1994). This is to be expected: countries entering into IMF programs will often implement policy adjustments that have the immediate impact of reducing demand but could ultimately create the basis for sustained growth. The structural reforms embedded in IMF programs inherently take time to improve economic performance. Finally, the crisis that led to the IMF program, not the IMF program itself, is often responsible for an immediate fall in growth.

Finally, there is a debate on the necessity of the final pillar of the current system, IMF support of macro adjustment and reform in very poor countries and transition economies. One view, espoused by the commission, is that any support to very poor countries should be transferred to the World Bank or MDBs, because the problems of these countries are too structural and complex. The view supported by the G7 and the IMF, instead, is that a proper division of labor between IFIs implies that the many macroeconomic problems of very poor and highly indebted countries should still be dealt with by the IMF in the context of a coordinated program of adjustment, reform, and growth with the World Bank.

This division of labor and coordination is at the center of the recently designed Poverty Reduction and Growth Facility (PRGF). In the PRGF, IMF concessional lending for macro adjustment was broadened to include an explicit focus on poverty reduction in the context of a growth-oriented strategy. The alternative of taking out of the IMF all the macroeconomic components of programs for poor countries has, in the view of critics, several shortcomings. First, these countries would effectively be nonmembers of the IMF and, as such, would feel excluded from the international financial system. Who would be "kicked out" of the IMF, and who would be readmitted, would be a politically charged issue. Second, it is not obvious that the World Bank has the appropriate expertise in the macroeconomic area and the effectiveness to enforce macro conditionality credibly in its pro-

75. Conway (1994) found that inflation fell following an IMF program, and the result was statistically significant. Bagci and Perrudin (1997) also found a statistically significant reduction in inflation. Dicks-Mireaux, Mecagni, and Schadler (1997) found that programs do reduce inflation, but the result was not statistically significant.

76. Bordo and Schwartz (2000) compare countries receiving IMF assistance during crises in the period 1973-98 with countries in the same region not receiving assistance and find that the real performance (for example, GDP growth) of the former group was possibly worse than the latter. 
grams. ${ }^{77}$ Other objections to the proposal include that the IMF, in phasing out its longer-term facilities such as the EFF, would not be able to deal with the problems of transition economies.

In general, the issue of whether the IMF should make loans to very poor countries or provide long-term facilities to countries with structural problems remains controversial. One can make arguments both ways.

A set of reforms of the IMF was agreed by the member countries at the time of the IMF meetings in Prague in September 2000. The reforms did reflect parts of the Meltzer Commission recommendations that were consistent with the views of the United States and the other G7 countries. Indeed, the IMF reform proposals advanced by the U.S. Treasury, although developed before the commission presented its report, were partly aimed at deflecting criticism of the IMF in congressional circles and preempting possible recommendations of the commission. The U.S. Treasury's reply to the commission report found a series of common reform goals that were shared by the commission and the U.S. administration. These included agreement that the IMF should continue to have an important role in crisis prevention and a strong capacity to respond to financial crises; a radical change in the transparency of the operations of IFIs and of member countries; the development of new mechanisms for strengthening incentives for countries to reduce their vulnerabilities to crises; a focus within the IMF on the importance of sound financial systems, better debt and liability management policies, and appropriate exchange rate regimes; and the need for a clear division of labor between the MDBs and the IMF.

Despite these broad common objectives, however, the U.S. administration remained "in fundamental disagreement with the Report's core recommendations for further reform" (U.S. Treasury 2000). Thus, although the reforms agreed upon by the G7 were consistent with the spirit of the commission goals, their detailed substance was substantially at odds with the more radical recommendations of the commission. The reforms agreed upon by the G7 and the IMFC at the time of the Prague meetings are discussed in more detail later, in the section "Recent G7 Initiatives to Reform the International Monetary Fund."

\section{Mission Creep}

Perhaps the most widely held criticism of the IMF is that it has exhibited "mission creep," a term borrowed from the history of military interventions that eventually expand beyond their originally stated aim. There is some truth to this critique. ${ }^{78}$ The fund has undergone significant role changes, roughly once a decade.

77. Some even argue that existing structural conditionality in World Bank programs is too soft and thus that IMF macro requirements and monitoring effectively become a useful crossconditionality for World Bank programs and loans.

78. See Feldstein (1999a) for a critique along these lines. 
The IMF's original mandate, under the Articles of Agreement negotiated at Bretton Woods, New Hampshire, in 1944, was to help countries with balance-of-payments difficulties, so as maintain a stable system of pegged exchange rates. A majority of members were industrialized countries. The goal of restoring convertibility among most industrialized countries had been achieved by the end of the 1950s. When the Bretton Woods system of fixed exchange rates broke up in the early 1970s, some charged that the IMF had lost its mission but, in good bureaucratic tradition, refused to go out of business; instead, it was filling the gap by turning its attentions to the developing countries, most of which had become independent over the preceding fifteen years (Niehans 1976). This seemed an unfair criticism. The newly independent countries had as much right to belong to the fund as anyone, and most of them maintained some type of exchange rate peg long after the major industrialized countries had given them up. (There were plenty of problems to keep policymakers busy in the 1970s, with the need after the oil crises to recycle surpluses in oil-importing countries to deficit oil importers.) Thus, even a narrow interpretation of the fund's role includes balance-of-payments problems in developing countries.

The role expanded in the international debt crisis of the 1980s. From its inception in 1982, Managing Director Jacques de Larosiere was active in the strategy to manage the crisis. It was a case-by-case approach (much as in the more recent episode), consisting of country programs that each featured three elements: policy adjustments by the country in question, loans from the IMF and industrialized-country governments, and agreement by private bankers to roll over loans or provide new money.

The next big change in the fund's role occurred with the unraveling of the Soviet Bloc. The formerly Communist countries - now transition economies - joined (or, in a few cases, re-joined) the IMF. Clearly the problems in their transition extended far behind the standard IMF issues of macroeconomic policy, exchange rates, and the balance of payments. Here, however, the IMF faced the first of its big cases of "damned if you do, damned if you don't." It is universally agreed that a necessary condition for economic success in the transition economies is the establishment of property rights, the rule of law, and other well-functioning institutions. A common critique is that the G7 and the IMF did not appreciate the importance of these factors, and the extent and importance of corruption in Russia in particular, and failed to do anything about them. At the same time, an equally common critique is that the IMF engaged in mission creep in the transition economies, by taking on tasks of structural reform that are more properly left to the World Bank. One could argue that a clearer division of labor and coordination between IMF and World Bank would have solved these opposite claims, but such an ideal outcome was certainly not easy to achieve.

The most recent evolution came with the emerging market crises of 1997 
98. The IMF did not simply apply the same approach to East Asia that it had applied in the past to Latin America or other problem debtors (even if some of the macro components of these plans - tight fiscal policy and tight money-were initially similar). The new country programs emphasized structural reform more than macroeconomic austerity. This was appropriate, in that these countries have historically followed good monetary and fiscal policies. Restructuring of the banking system and strengthening of prudential supervision are prescriptions that are closely related to the roots of the crisis, and thus they are appropriate subjects for IMF attention and conditionality, even if it means having to hire new personnel with expertise in this area. Issues of corporate governance or trade liberalization are also relevant, although they could be viewed as a bit more afield. At the extreme, issues of the environment, labor rights, and human rights, although extremely important in the wider scheme of things, are clearly not relevant for the IMF's mandate. ${ }^{79}$

To include issues of banking supervision and corruption in the IMF purview certainly represents a relocation of the boundary line that separates the legitimate territory of multilateral governance from the inviolable territory of national sovereignty. How can this be justified? For years, the word "corruption," like the words "military spending," was virtually taboo at the IMF, because the governments of the member countries, who own and run the fund, did not want either of them discussed. The inability to look at issues of military spending and corruption undermined the effectiveness of IMF programs, increasing the burden of austerity on the local population and decreasing the financial effectiveness of the programs. Perhaps the strongest argument for including such structural conditionality in IMF programs is that it is impossible for the international community to justify sending additional resources to a crisis country if everyone believes that the money will end up in the bank accounts of government cronies. As national economies become more highly integrated, it is not surprising if an accounting of costs and benefits results in some moving of the boundary, pushing back national sovereignty, in some well-chosen areas. Where the integration is financial, attempts by the international financial community to address any resulting crises may end up including structural conditions that, although going beyond macroeconomics, are nonetheless relevant to the origin of the crises and to their effective solution.

Macroeconomic conditionality alone could not solve the Indonesia crisis of 1997-98, because neither an overvalued currency nor excessive budget deficits were the original problem. Even best efforts to address problems of the banking sector would probably not have been able to solve the crisis.

79. Thus, recent U.S. congressional mandates that force the administration to push issues of trade liberalization, labor and union rights, and environmental issues on the IMF agenda and condition U.S. votes on IMF programs on IMF consideration of such issues are seriously misguided. 
The ultimate origins of the Indonesian financial crisis were deeply rooted in corruption, the uncertainties of presidential succession, and the lack of commitment to policy adjustment and reform and the vulnerability of the Chinese minority. Many criticized the IMF program for a list of conditions that was so detailed as to include a dismantling of the clove monopoly; they miss the point that precisely such steps were deemed to be necessary to signal to investors that the economic interests of the president's family would no longer be allowed so fundamentally to distort the national economy. Many criticize the fund and the G7 for failing to realize that the president would never deliver on such promises; they miss the point that his failure to try to deliver is what led to his removal, in favor (eventually) of someone who might. Many criticize the fund, the United States, and the entire international financial community for having supported Suharto all those years. They miss the point that it is neither feasible nor proper for the international community to remove local rulers, leaving aside extreme cases of egregious military threats, but that rulers may be forced by domestic constituencies to leave office as the result of a financial crisis that is in turn the consequence of their bad policies.

The fund is arguably intruding on the traditional territory of the World Bank in three ways. The first, as just discussed, is the expansion beyond macroeconomic conditionality to include structural conditionality. The second is the increased emphasis on poverty reduction, embodied in the renaming of what is now the PRGF. The third is the drift toward programs with longer terms, or toward a pattern of programs that are repeatedly renewed.

It is on the topic of poverty that the IMF is most thoroughly damned by critics either way. Expert assessments from across the political spectrum recommend a clearer division of responsibility between the two agencies, including a decision to leave poverty fighting to the World Bank. On the other hand, critics hit the target with as much punch as the charge that the IMF serves the interest of wealthy capitalists, in both creditor and debtor countries, and that it is the poor who suffer the most unpleasant consequences of adjustment programs. A division of labor may be sensible as a matter of good public policy. Political considerations are also relevant, and protestors concerned with the poor will not like to be told "that is the World Bank's job." However, they don't react much better when they are told "we are working on it," so the fund may not have much to lose by giving the World Bank exclusive rights to the topic of poverty.

Finally comes the question of the length of time that patients are hooked up to the IMF support system. Not long ago, most programs ended in a few years, and the borrower repaid the fund. It is still true that defaults to the fund are exceedingly rare. However, programs that are designed to be long term became more common in the 1990s (the EFF for countries with longer-term macro and structural problem or in transition to a market 
economy and the Extended Structural Adjustment Facility [ESAF] for very poor and highly indebted countries), as did cases where programs are repeatedly extended or rolled over. There is an open debate over whether the fund should engage only in very short-term financing or be involved in longer-term funding to support structural adjustment.

Some argue that the division of labor between the IMF and the World Bank may need to be restored toward its traditional balance. In this view, the World Bank's proper role is more extensive attention to structural issues, with special attention to poverty reduction, carried out through longterm lending programs. The fund's proper role would instead be addressing shorter-term issues, particularly including financial or currency crises. Thus, in additional to traditional macro issues, IMF surveillance would also cover the soundness of financial systems, whose weaknesses were at the root of many recent crises. Even here, a division of labor could be implemented: the specific financial system reforms necessary to the restoration of confidence, macro stability, and growth may remain under the IMF realm; those regarding the medium restructuring of the banking, financial, and corporate sectors could be taken over by the World Bank. Moreover, given the partial overlap of issues in the financial area, the two institutions could cooperate and coordinate their action in this area. However, this is only one of the ways in which the division of labor between the two institutions could be arranged.

Of course, a large percentage of IMF members, and a still larger percentage of users of IMF programs, is and will continue to be developing countries. And as the World Bank continues to place greater emphasis on the important goals of poverty reduction and environmental protection in its longer-term development programs, it is important to coordinate closely with the fund. The warning that monetary stability is a precondition both for increasing aggregate income and for equitable income distribution is as true as it ever was.

Recommendations that the fund turn some responsibilities back over to the World Bank are not necessarily the same as agreeing with the argument that it has been guilty of a self-serving expansion of authority. In the heat of a crisis, actors scramble to cover whatever positions need covering. Perhaps it is inevitable that a smaller, more nimble institution, as the fund is, will be quicker to step into a gap that opens up in such areas as banking regulation or corporate governance. However, even supporters of the IMF's broadened role in the past few years say that it is now appropriate for the actors to return to their assigned positions.

\section{Recent G7 Initiatives to Reform the International Monetary Fund}

The drive to reform the IMF picked up speed in the fall of 1999 for a number of reasons. First, the IMF had been subject to a number of critiques in the wake of the Asian crisis, and it was useful to reassess its role and func- 
tions. Second, the recovery of the Asian and world economy from its crisis mode allowed attention to concentrate on how to improve the international financial system and its main constituent bodies. Third, in the United States the congressional resistance to IMF refunding in 1998 showed the need to address some of the concerns expressed regarding the role of the IMF. Congressional action to set up the Meltzer Commission, congressional legislative mandates on areas where the United States should press the IMF in program design (labor issues, trade questions, etc.), and the need to receive congressional support for initiatives such as HIPC funding were also factors. Fourth, the G7 dialogue on architecture reform that started in 1998 suggested that the $\mathrm{G} 7$ would look at the issue of the reform of the IFIs.

The United States again took a leadership role in this debate. U.S. Treasury Secretary Summers presented in a December 1999 speech (Summers 1999) the U.S. view on how to reform the IMF. The ensuing dialogue among the $\mathrm{G} 7$ countries led first to a consensus on the main outlines of IMF reform by the time of the spring annual meetings of the IMF and World Bank (April 2000) and then to a more detailed consensus and approval by the IMF board of specific proposals by the time of the fall annual meetings (September 2000 in Prague).

The main elements of the U.S. proposals, which were largely adopted by the G7, were as follows:

- Promotion of the flow of information to markets, that is, a shift of IMF surveillance to promoting the collection and dissemination of information for investors and markets. This took the following operational form: (a) IMF encouragement of more countries to adopt and comply with the SDDS, including its new provisions relating to the reporting of reserves and addition to the SDDS of greater reporting of external debt data; (b) encouragement of countries to implement international standards and codes for sound policies; and public release of these assessments (the ROSCs); and (c) a request that independent external audits of central banks and other relevant government entities be done and published.

- Emphasis on assessment of financial vulnerabilities, not just macroeconomic fundamentals, that is, a greater focus on the strength of national balance sheets to reduce liquidity and balance sheet risk at the aggregate and sectoral level through greater use of indicators of external vulnerability and better collection of data on external debt (via the SDDS) and via the development of guidelines for optimal public debt management. The United States also supported highlighting more clearly the risks of unsustainable exchange rate regimes by supporting corner regimes. Although the IMF has placed renewed emphasis on the importance of sustainable exchange rate regimes, the overall G7 consensus on this is not as radical as the U.S. position. Other G7 mem- 
bers agree that exchange rate regimes should be sustainable but do not fully endorse the U.S. support for corner regimes in most cases..$^{80}$

- A focus of the IMF's attention on its core competencies (macroeconomic and financial-sector stability) and a focus of its finance on emergency situations. This meant a more limited financial involvement of the IMF with countries, lending selectively and on shorter maturities. It also meant an IMF on the front line of the international response to financial crises, but not as a source of low-cost financing for countries with ready access to private capital, or long-term support for IMF "addicts" - countries that cannot break the habit of bad policies and repeatedly depend on IMF financial support. In the U.S. view, this implied a reform of IMF facilities to streamline and eliminate some longer-term facilities (such as the EFF and other smaller, narrowly designed funds and facilities). It would also change the pricing of the remaining three main facilities (CCL, SBA, and SRF) to charge higher interest rates and limit the duration of most loans for the SBA and SRF and reduce the charges on the CCL to give incentives for its use by sound economies. On one side was the strong U.S. support of easier conditions for CCL access (given its support of this facility and the lack of countries applying to it after its design in 1998) and skepticism of the longer-term EFF. On the other side was the European view that the EFF should be maintained (especially for transition economies and poorer countries) and the CCL not eased too much (out of concerns about moral hazard and excessive large financial packages). The eventual G7 consensus ratified in September 2000 by the IMF executive board eased the conditions for the CCL but maintained a role for the EFF (and eliminated most of the smaller facilities) while limiting and concentrating its use for transition economies and countries graduating from the PRGF program (the new successor to the ESAF program for poor and highly indebted countries). The relative pricing of the three main facilities was also changed to incentivate CCL use and discourage longer-term use of SBAs and SRFs. Measures to reduce IMF "addiction" (repeated use of IMF support) and strengthen postprogram monitoring were also agreed upon.

- Modernization of the IMF as an institution. This was to take place via greater transparency (publication of a large number of official documents) and openness (dialogue with civil society and nongovernmental organizations [NGOs] and with the private financial sector through the new Market Conditions Consultative Group), including regular publication of the IMF's operational budget. The United States also

80. We did not discuss the very important issue of the appropriate exchange rate regime for emerging markets because it is discussed in another paper from this conference (chap. 1 in this volume). The views of one of the coauthors of this paper can be found in Frankel (1999). 
supported a governing structure that is more representative and a relative reallocation of member quotas. However, reform of IMF quotas has remained highly controversial and a consensus has so far eluded the G7 and emerging market countries. An increase in the quotas of emerging markets is envisioned in most reform solutions (for example, those of the official Quota Formula Review Group or "Cooper Group" after the name of its chair). However, this would also imply a shrinkage of European countries' quotas (which currently compose one-third of the executive director positions within the IMF board), a solution strongly resisted by the European countries.

- A new focus on growth and poverty reduction in the poorest countries via efforts to translate debt relief for the HIPC into concrete reductions in poverty through the PRGF.

The above reforms of the IMF proposed by the G7 at the time of the G7 summit were endorsed by the IMFC at the time of the IMF meetings in Prague in September 2000 and operationalized during the fall of 2000, especially the reform of the IMF facilities. Regarding the latter, the CCL was enhanced by reducing the surcharge on the use of credit under the CCL and the commitment fee and by increasing the amount of funds available for borrowing at the time of activation. The use of the longer-term EFF was restricted and the time period for repayment of EFF loans reduced. Similarly, the repayment period for standby loans (purchases in the credit tranches) was also reduced to incentivate faster repayment of IMF loans. Conversely, the interest rate on exceptionally sized loans, such as those in the SRF, was increased based on an increasing scale. Finally, postprogram monitoring by the IMF of economic developments and policies after the end of a program was operationalized.

\subsubsection{Proposals for Alternative Institutions and Tools for Crisis Prevention and Resolution}

In this part we discuss a number of proposals for an international LOLR and alternative institutions and mechanisms and tools to deal with international financial crises, both in the crisis prevention and crisis resolution areas. $^{81}$

\section{International Lender of Last Resort}

There has been a wide debate on how liquidity crises are to be addressed: full bailout by an international lender of last resort (ILOLR) or bail-in (appropriate PSI)? In cases in which there is a pure liquidity crisis the case for

81. Eichengreen (1999a) and Rogoff (1999) consider a broad range of plans, including a global lender of last resort facility, an international bankruptcy court, an international debt insurance corporation, and unilateral controls on capital flows. 
an ILOLR might have a stronger basis. At the national level, the central bank can carry out the LOLR function when there is a liquidity run on domestic banks. There is no international equivalent of an LOLR, however. The IMF comes closest, but it does not have the capacity to provide unlimited funds to countries in crisis or to print or create international liquidity at will. Thus, several authors (e.g., Fischer 1999) have suggested that an ILOLR function should be bestowed on the IMF or on some equivalent international institution (a global central bank, as proposed by Jeffrey Garten in "In This Economic Chaos, A Global Bank Can Help," International Herald Tribune, 25 September 1998, 8).

Indeed, some argue that in pure liquidity cases, large bailout packages are justified and no PSI (bail-in) of private investors is warranted. Thus, the debate on whether an ILOLR is necessary in liquidity cases has been strongly linked to the debate on whether PSI is necessary in liquidity cases. As the discussion below suggests, the issue is much more complex than the simple argument that a full bailout via an ILOLR is appropriate in pure liquidity cases.

\section{Full Bail-out (an ILOLR Function) or Full Bail-in in Liquidity Cases? Some Conceptual Issues}

An official G7 doctrine for pure liquidity cases has not been fully articulated because of the complexity of such cases. Indeed, even the official PSI framework as elaborated by the G7 only partially addresses the question of what to do, if anything, in liquidity cases, especially if the country is large and has systemic effects. ${ }^{82}$

The issues in these liquidity cases are very difficult. First, it is not obvious whether there are "pure" liquidity cases. Formally, a crisis country may not be insolvent but rather illiquid in the sense that its debt-servicing problems are caused by sudden illiquidity; however, even such a country may have weak fundamentals and serious policy shortcomings. Indeed, it is hard to believe that a country with fully sound fundamentals and policies would become illiquid and subject to self-fulfilling speculative runs and panic. For one thing, even in theory, if fundamentals are strong enough such multipleequilibria runs may be ruled out: that is, weak fundamentals are necessary for an economy to be in the multiple-equilibria region. Also, empirically all

82. The PSI framework is meant to cover both liquidity cases and semi-insolvency or insolvency cases, but it emphasizes the latter and de-emphasizes the former. The preamble of the G7 operational guidelines suggests two approaches to liquidity cases: catalytic financing and voluntary arrangements that recognize the collective interest in staying in. The overall approach to liquidity cases is case-by-case but constrained by the PSI framework, as for the other cases. However, the $\mathrm{G} 7$ has not addressed head-on the role that restructurings or reprofilings should play in liquidity cases. For example, one should not lump the PSI approach to Korea with that to Brazil, because the commitment to stay in Korea was much firmer and led to formal extension of maturities via rescheduling. Moreover, the G7 guidelines for restructuring do not explicitly apply to liquidity cases. Thus, there is still a lot of room for fleshing out the G7 views on liquidity and systemic cases. 
observed cases, in which something close to an illiquidity problem was the proximate cause of the crisis, were characterized by some fundamentals or policy weaknesses. In cases like those of Mexico, Korea, Thailand, and Brazil, which are conceptually closer to the illiquidity problem, some serious macroeconomic, structural, or policy shortcomings certainly played a role in triggering the crisis. Thus, talking of pure liquidity cases and what, if any, PSI to implement in such cases is somewhat unrealistic.

However, for the sake of the conceptual argument, let us consider first "pure" liquidity cases. Some argue that a solution closer to very large official support packages (full bailout via an ILOLR) may be warranted in cases of pure illiquidity. It is also argued that this full bailout solution might be necessary if the country is not only illiquid but also large and of systemic importance. ${ }^{83}$

Although in such pure liquidity cases one could conceptually make the argument that a full bailout is the efficient policy, one could also argue that the alternative policy of a full bail-in (i.e., a combination of wide standstills, capital controls, and other measures to lock in all investors that are rushing to the exits) is as efficient and optimal. Indeed, if there is no uncertainty and no risk aversion, and there is a pure liquidity problem or run, both the full bailout and the full bail-in are equivalent solutions to the collective-action problem faced by investors (the coordination failure) that is the cause of the liquidity-driven run. So, paradoxically, the full bail-in solution is optimal even in the cases in which the full bailout solution appears warranted.

Paradoxically, in these pure liquidity cases, the bail-in solution may be superior to the bailout one because the ex ante threat of a full bail-in solution is sufficient to sustain ex ante the good equilibrium of "no run" without having to resort to such a threat ex post. In fact, if all agents know that if and when a run occurs the official sector or debtor will introduce standstills

83. A complex issue to be discussed below is what to do if the country is large and systemic but its crisis is not purely due to illiquidity: that is, what to do if serious macro and policy shortcomings are at the root of the crisis. The current IMF/G7 doctrine for both systemic and nonsystemic cases suggests that, when catalytic IMF financing, policy adjustment, and soft or voluntary forms of PSI are expected to restore market access and investors' confidence, this route could be followed, but should be substantially justified when exceptional financing is involved - not precluding the use of stronger forms of PSI if such catalytic approach does not succeed. The recent use of exceptional financing in the cases of Argentina and Turkey could have been rationalized by arguing that these may be cases in which catalytic financing and policy adjustment were deemed to be likely to restore market access and investors' confidence. However, the use of stronger forms of PSI cannot be ruled out in case this catalytic approach were not to succeed as indeed became the case in Argentina. Moreover, the Turkish package includes a soft form of PSI à la Brazil and in the spirit of voluntary approaches to PSI: the Turkish authorities met in midDecember with their bank creditors and received commitments that such creditors will maintain their cross-border exposure to the country. The expectation that such exposure would be maintained was reaffirmed by the IMF even when the Turkish peg broke in February 2001. Thus, the large packages for Turkey and Argentina in late 2000 cannot not be interpreted as cases in which PSI was neglected or ruled out altogether. However, in the Turkish case, the significant roll-off of cross-border interbank lines since the February 2001 devaluation makes doubtful the argument that soft and voluntary commitments to maintain exposure can be credible or effective. 
or capital controls to avoid the run, the incentive to run will disappear because everyone will know that no one will have the incentive and desire to rush to the door and no real losses will be incurred. In the domestic analogue, no one will want to stand first in the line at the bank if a bank holiday prevents the run from occurring. Thus, the threat of a full bail-in could be sufficient to rule out the bad equilibrium: ex post, no run will occur and the threat will not be exercised, thus avoiding the need to implement the threat in the first place.

This conceptual superiority of the full bail-in solution is, however, extremely fragile in practice. In fact, if (a) the case under consideration is not one of pure illiquidity but one in which some policy shortcomings are behind the illiquidity, (b) there is some uncertainty about the fundamentals and the policy response to the crisis, and (c) creditors are risk-averse, the dominance of a full bail-in solution will break down. When fundamentals are weak and uncertain and agents are risk-averse, they will react to the expectation or threat of a bail-in by rushing to the front of the line because the threat of a bail-in may actually be implemented. Consequently, this bail-in may imply real costs and financial losses to investors when the country is subject to shortcomings of policy and fundamentals rather than being purely illiquid.

What, then, is to be done in liquidity cases, especially considering that some policy shortcomings imply that these are not going to be "pure" liquidity cases? A full bail-in, a full bailout, or something in between? One view is that, if one were to apply the logic of PSI (i.e., that some external financing gaps may occur) that official money will not be enough to fill such gaps and that a solution based only on official money (full bailout) is not appropriate because of moral hazard distortions, then the official sector would want to do a combination of things. Specifically, part of the solution would be policy adjustment by the debtor country if macro, structural, and policy shortcomings caused the crisis. Part of the solution would be official money: the larger the package, when one is closer to a pure liquidity case, and the smaller when shortcomings are important. Additionally, part of the solution might be appropriate forms of PSI that are more or less "voluntary" depending on the circumstances and the nature of the problem being addressed. These bail-ins may take the form of "partial" bail-in (i.e., they may include only a subset of instruments and creditors that may be running).

Indeed, in recent liquidity cases (Mexico, Korea, Brazil), the response has been a combination of policy adjustment, official money, and PSI, with the relative weights being different in different circumstances. Mexico was a case closer to that of full bailout of investors (cum domestic policy adjustment). Korea was closer to a semicoercive rollover of interbank lines because the loss of foreign reserves had put the country close to the brink of default in the face of the attempt of foreign banks to reduce their exposures. Brazil was in between with a mild form of PSI (a monitoring of bank exposure followed by a commitment to maintain exposure at reduced levels). 
This, combined with policy adjustment and significant official support, was successful in avoiding a wider loss of confidence and prevented a disruptive loss of market access.

The official-sector response to these liquidity cases has been based on the view that a combination of adjustment, catalytic official money, and appropriate PSI (partial rather than a full bail-in) can be successful in preventing a wider crisis, restoring confidence and market access, and returning the country to a path of recovery and growth.

Conceptually, however, the "middle" solution, as opposed to the corner solutions of full bailout or full bail-in, has been challenged as not being feasible. Observers (such as Paul Krugman) have argued that only corner solutions are feasible in these liquidity cases: ${ }^{84}$ either there is an ILOLR with enough resources to engineer a full bailout and avoid a disruptive run, or, at the other extreme, a full bail-in (that locks in all assets and domestic and foreign creditors trying to turn short-term claims into foreign assets) is necessary. In fact, in this view a partial bail-in would not work because, as long as the economy is in the multiple-equilibria region, locking in some creditors and assets, but not all, would lead all the others to run to avoid being locked in next. Conversely, a partial bailout would not work either because, as long as the financing gap is not eliminated, the multiple-equilibria problem is not solved and agents will rush to the exits and trigger a default by claiming all the limited foreign reserves, including those provided by the partial official support. Thus, conceptually, it is argued that the middle solution may not be feasible.

Indeed, the Krugman hypothesis is supported by some theoretical work. Zettelmeyer (2000) formalizes this hypothesis by showing that partial bailouts are bound to fail in models in which illiquidity may lead to selffulfilling speculative attacks. Such partial bailouts (or bail-ins) would not avoid the possibility of a bad equilibrium because, as long as the size of the support is not large enough to fill the financing gap, the possibility that agents will coordinate on the bad equilibrium cannot be ruled out. Worse, a partial bailout implies that the greater is the official support, the larger is the reserve loss if a run occurs. Indeed, if a partial package cannot avoid a run, the operating constraint on the size of the run is the amount of official reserves (including those provided by the bailout package); thus, more support in this case means only a larger run on reserves.

This theoretical ineffectiveness of middle solutions (partial bailouts and partial bail-ins) is in contrast to the official-sector PSI doctrine that catalytic official money, domestic policy adjustment, and partial and appropriate bail-in might indeed succeed and avoid the bad equilibrium even

84. King (1999) is substantially in favor of "middle way" solutions but also suggests that corner-type solutions (such as broad standstills on debt payments) may at times be necessary to stem a crisis. The issue of standstills has been discussed in more detail in section 3.1.2. 
when such a three-pronged solution does not formally fill all of the external gap. The middle solution is predicated on the view that this combination of actions will restore confidence and lead investors who are not bailed in, and who could thus run for the exit, to avoid running even if the remaining external financing gap is large enough that if they were to decide to run the bad equilibrium could not be avoided.

The gap between the theoretical analysis (which supports the corner solutions) and the actual policies and case studies (which support the view that middle solutions can be successful) can be bridged as follows. In multiple-equilibria models, as long as the financing gap is not completely filled via full bail-in or full bailout, the possibility of a self-fulfilling run cannot be ruled out completely: The economy may end up in the bad equilibrium if those who are not bailed in do decide to rush to the exits. Moreover, in the multiple-equilibrium region, there is nothing (apart from "sunspots") that can nail down the probability that the economy will end up in the bad equilibrium as opposed to the good equilibrium. Since the bad equilibrium requires that enough agents decide to focalize on that equilibrium (i.e., decide to run), the question is how much fundamentals and policy actions can affect such decision. In existing models, this probability is indeterminate, and the economy may be as likely to end up in one equilibrium as the other.

In reality, however, domestic policy choices, official support, and the amount of bail-in $d o$ affect the probability, even if they do not do so in current analytical models. Indeed, the argument for a middle solution is based on the view that domestic policy adjustment will reduce the probability of a run as the debtor government credibly commits to reduce the imbalances that created the risk of a run in the first place. Also, the amount of official support can also affect the probability of a run because more official money means that the size of the remaining gap is proportionally reduced. And appropriate PSI may also reduce the probability of a run by leading some investors and asset classes to stay in (resulting in a voluntary or concerted rollover) and leading the others who are not subject to bail-in not to run as the domestic adjustment, the official money, and the bail-in of other investors help to restore the confidence of the remaining ones. Thus, although a theoretical understanding for middle solutions (with different degrees of partial PSI) has not been developed, they do appear to work in practice, as recent episodes (in Mexico, Korea, and Brazil) seem to suggest.

In practice, this has led the G7 and the IMF to conclude that liquidity and systemic cases should be dealt with on a case-by-case basis: no simple or rigid rules can be applied, and all relevant factors may have to be considered to decide whether and how much PSI should be applied. Moreover, some argue that some degree of "constructive ambiguity" might have to be maintained in this regime to provide the appropriate response to specific cases and avoid expectations of systematic bailouts.

This view that middle solutions may work in practice does not go un- 
challenged. Some argue that recent episodes, such as those in Mexico, Korea, and Brazil, are consistent with the view that only corner solutions can work. Indeed, the evidence from these three case studies is ambiguous on whether middle solutions are feasible. All cases had some middle-solution component because official assistance was well below the size of assets that could have been run upon, but a careful analysis suggests that these cases are also, in some dimensions, closer to the corners. ${ }^{85}$

Moreover, corner solutions have a number of practical shortcomings: a full bail-in, as discussed above and as we discussed in more detail when we considered standstills ("Moral Hazard and Private-Sector Involvement in Crisis Resolution"), may lead to a rush to the exits and contagion in a world of uncertainty and risk-averse investors. At the other extreme, a full bailout solution also implies the existence of an ILOLR that might be problematic for reasons that will be discussed next.

\section{ILOLR, Too-Big-to-Fail Doctrine, and Appropriate PSI}

What can a full bailout solution achieve, and does it require the existence of an ILOLR? Because countries suffering illiquidity often do so because of some fundamental or policy weakness, if unlimited resources were available to a country with fundamental weaknesses, the funds lent by an ILOLR facility would be used by domestic and foreign investors to liquidate domestic assets and turn them into foreign ones, eventually exacerbating the crisis rooted in weak fundamentals. This is also the reason why, in a domestic context, it would be destabilizing to give extensive and unconditional LOLR support to banks that are in serious financial distress or bankrupt. Allocating more funds to such banks leads to moral hazard (i.e., "gambling for redemption"), as the savings and loan crisis and many other episodes suggest. This is also why the response of a central bank to a banking crisis caused by poor behavior of the banking system is to provide emergency support (to avoid panic) in exchange for very strict controls and restructuring of the financial institution under distress.

In an international context, there are three implications of the above observations.

First, if a country in severe distress because of fundamental weaknesses received unconditional ILOLR support, such support would bail out investors and eventually fail to prevent a crisis, because the country is in serious fundamental distress in the first place. Second, if support is aimed at providing incentives for reform and adjustment, then the support is likely to be of the conditionality form that comes with IMF packages. Third, if bailing in private investors is motivated by the goal of reducing moral hazard, the amount of support would have to be lower than the amount of total domestic assets that could be potentially converted into foreign currency; that 
is, official financing support that is only partial would contribute to reducing such moral hazard distortions.

What about the issue of big money packages? How large should IMF packages be, and under which conditions should exceptional finance be provided? In the early decades of the life of the IMF, when international capital mobility was not widespread and restrictions to capital flows dominant, it historically was not allowed to provide large and exceptional support for crises generated by capital account problems. The IMF was restricted to providing financing limited to current account problems. Capital account liberalization and the growing size of international capital flows led to the emergence of financial crises driven by capital account problems, the type of liquidity crises associated with the existence of large stocks of shortterm foreign debt that may not be rolled over when confidence was lost. Hence, the trend to develop facilities such as the SRF, the General Agreements to Borrow (GAB), the New Agreements to Borrow (NAB), and the CCL, which would allow these capital account crises to be addressed.

Consider now the issue of exceptional packages. Assume that a country experiencing a crisis because of weak fundamentals is large, suffers from a liquidity problem, is systemically important, is a potential source of contagion to other countries, and suffers a capital account crisis (due to creditors' unwillingness to roll over bank loans and other short-term claims); a large financial package significantly in excess of quota may be able to stem default due to illiquidity and avoid further international contagion.

In this respect, such big packages for systemically important countries are the international equivalent of the too-big-to-fail (TBTF) doctrine in the domestic LOLR context. Just as governments do not usually let big banks fail even if not all of their liabilities are covered by deposit insurance because of concerns of systemic effects and contagion to other sound banks, so the international community may act to prevent big countries from defaulting for the same reasons.

A domestic TBTF doctrine may increase the risk of moral hazard. However, in a domestic context there are a number of mechanisms that limit such a risk; also, there are differences between the domestic and international economy context that may exacerbate the moral hazard problem in the international context.

First, in a domestic economy both large and small banks are subject to ex ante direct regulation and supervision, reserve requirements, capital adequacy standards, deposit insurance with risk-adjusted premia. Thus, supervisors and regulators have broad powers to control the behavior of such banks before financial distress forces the authorities to bail them out.

Second, although the FDICIA provides an out for systemically important institutions, such a doctrine was never formally embraced by the Federal Reserve and there are a number of hurdles to such TBTF rescues: the Federal Board has to take a major vote and there has to be concurrence by 
the secretary of the treasury. Moreover, some constructive ambiguity is used to prevent expectations that large institutions will be systematically rescued on a regular basis.

Third, once a TBTF institution is rescued, the authorities have a broad range of powers to dispose of it: it may be cleaned up, recapitalized, merged with other institutions, or even closed down and liquidated. Also, although an institution may be rescued to avoid systemic contagion, its managers and shareholders may be replaced. Thus, the moral hazard problems of rescuing the institution are reduced, even if there is still the issue of covering the depositors, including the uninsured depositors.

In an international context, the idea of taking over countries, closing them down and merging them with others, or replacing their shareholders is quite meaningless (in an era when, fortunately, debtor's prison and gunboat diplomacy are no longer options). Moreover, the kind of preventive regulation and supervision that are imposed on TBTF institutions in a domestic context is also severely limited in an international context. Sovereignty issues as well as the lack of leverage of the IMF over countries that are not yet in a crisis, and thus do not have an IMF program, limits the ability to provide such ex ante supervision and regulation. Thus, although in a domestic context moral hazard deriving from expectations of TBTF support may be tempered with adequate supervision and regulation, the same cannot easily be done in an international context.

In general, although TBTF arguments for big money packages for systemically important countries have some merit, the potential moral hazard distortions created by such programs have to be carefully addressed. In an ideal world, one would provide relatively large money packages mostly to sound economies without any substantial weaknesses (the type of economies that qualify for the IMF's CCL support). One would want to minimize the use of big money packages for the many cases in which serious fundamental fragilities interacted with illiquidity to generate financial crises. If one had to design a long-term regime from scratch, big money packages would not normally be part of the rules of the games, apart from very clear liquidity cases and cases in which significant contagion is due to systemic effects ${ }^{86} \mathrm{~A}$ credible commitment to avoid big money would force borrowers and creditors to be more cautious in their investment and borrowing decisions; and, if crises did occur because of a loss of confidence, adequate market mechanisms to avoid a generalized financial meltdown (orderly workouts, concerted market-based rollovers, insurance schemes based on private credit lines) would be found.

This purely market-based solution with no big money bailouts may not be feasible or credible in the current regime, and even in an historic perspective banking crises and international financial crises were messy and protracted when domestic and international financial LOLRs were missing.

86. This is the logic of having a facility like the IMF's SRF. 
However, if investors, debtors, and the official sector will continue to live in a world where the TBTF doctrine will be at times implemented for countries that are systemically too important and contagious, there is a need to design mechanisms that will minimize the moral hazard and the distortionary effects of such doctrine.

In a domestic banking context, the FDICIA increased the likelihood that uninsured depositors and other creditors would suffer losses when their bank fails. The fix was incomplete, however, because regulators can providesubject to a board decision with which the Treasury department must concur - full protection when they determine that a failing bank is TBTF - that is, when its failure could significantly impair the rest of the industry and the overall economy. Some, for example, the Minneapolis Federal Reserve, have argued that the TBTF exception is too broad; there is still much protection. Consequently, the Minneapolis Federal Reserve has proposed amending FDICIA so that the government cannot fully protect uninsured depositors and creditors at banks deemed TBTF. ${ }^{87}$ The proposed reform attacks the problem of 100 percent coverage by requiring uninsured depositors of TBTF banks to bear some losses when their bank is rescued. Such reforms, by increasing market discipline, may make bank runs and panics more likely.

Consider now how such proposals to limit TBTF-related moral hazard could be applied in an international context. The answer is that some form of private-sector burden-sharing would replicate the type of incentives suggested by the Minneapolis Federal Reserve to limit the perverse effects of an international TBTF. This means that, even (or especially) in cases of liquidity crises, investors would be expected to participate in burden sharing (commitment to rollovers, concerted semivoluntary rollovers, and even small haircuts depending on the circumstances) when a TBTF country is receiving a big money package. The need to limit moral hazard would thus be a fundamental reason for including meaningful PSI for large countries that are receiving big money packages. Indeed, systematically rescuing such large international investors - cross-border bank activities of international banks and highly risky investments of sophisticated international investors - on the basis of the risk of a run on a systemically important illiquid country would exacerbate the moral hazard problem of large rescue packages. ${ }^{88}$

87. This Federal Reserve proposal was first advanced in the Minneapolis Federal Reserve 1997 annual report; see [http://www.mpls.frb.org/pubs/ar/ar1997.html].

88. Avoiding these ex post bailouts of cross-border interbank creditors is easier said than done. As the recent crisis in Turkey in December 2000 suggests, such uninsured creditors may panic when there are problems in the banking system and they are worried about serious losses. Thus, they are likely to run if expectations of a serious banking crisis emerge; consequently, the monetary authorities might be forced, ex post and at the cost of moral hazard distortions, to extend deposit insurance to these uninsured cross-border liabilities to prevent a run. However, this provision of ex post insurance was provided under the proviso that international banks commit to maintain their exposure level to the level existing at the time of the crisis (December 2000). This was the main, but export failed, PSI component of the IMF rescue package in Turkey. A similar quid quo pro was implemented in Korea in 1997; the banks agreed to roll over their exposure into medium-term bonds in exchange for a government guarantee of such lines. 
In conclusion, the appropriate form of PSI in liquidity and systemic cases is a complex issue. The G7 and IMF approach has been to deal with these on a case-by-case basis, considering all factors in the case in deciding whether and how much PSI would be applied. Some degree of constructive ambiguity has been maintained in official doctrine and justified as necessary to provide the appropriate response to specific cases and minimize the moral hazard problem of TBTF expectations. Ideally, some combination of significant - but not systematically exceptional - official finance, domestic adjustment, and cooperative, semivoluntary, and least-coercive PSI of some categories of debt could restore confidence, prevent a wider crisis, and provide a middle solution to a crisis. Such a "middle-solution-cumconstructive-ambiguity" may address the trade-off between the need to avoid moral hazard deriving from systemic expectations of bailout and the risk that self-fulfilling runs occur in cases closer to the illiquidity corner.

Some Specific Proposals for New Institutions or Mechanisms/Tools to Prevent and Resolve Financial Crises

In the aftermath of any general crisis comes a variety of proposals for entirely new institutions or mechanisms to prevent and resolve crises.

\section{The Asian Monetary Fund}

The idea of an Asian Monetary Fund (AMF) was first advanced by Japan as a way to contain the emerging Asian financial turmoil in late 1997. The idea was that such a fund could pool regional resources to be used by countries in the region to defend their currencies against speculative attacks. The issue of an AMF became contentious as the United States successfully rejected this idea. It argued that it would compete with and duplicate the IMF and that there was a danger that the conditionality attached to the lending of this fund would be soft, undermining IMF conditionality and weakening the discipline to follow appropriate macro and financial policies. As the Asian crisis worsened, some lingering resentment remained among the Japanese and other Asians who argued that such a fund could have successfully stemmed or limited the Asian crisis and contagion throughout the region.

Such a fund might not have been successful in its short-run goal of ending the crises, even leaving aside the longer-run moral hazard issues. For example, Thailand almost exhausted its foreign reserves in the spring and summer of 1997 in spite of attempts to control the outflow of capital. It is not obvious that another $\$ 10$ or $\$ 20$ billion of borrowed reserves would have made any difference. Most likely it would have been lost and the eventual currency adjustment merely delayed. History suggests that when parities are unsustainable, sterilized intervention is ineffective and may just feed the short positions taken by speculators. Unsterilized intervention is more effective, but the same results on interest rates can be obtained through domestic open-market operations. One might argue that it may be better to save precious reserves that are a dam against liquidity risk and rather use 
domestic interest rate policy (domestic open-market operations) if a defense of the peg is deemed to be appropriate. Note, however, that policies of soft pegs before the crisis contributed to overvaluation, large current account deficits, lack of foreign exchange hedging, and moral hazard-related distortions to borrow in foreign currency. Thus, many believe that a currency adjustment was unavoidable in several crisis-affected economies in Asia and that neither unsterilized intervention nor interest rate defense could have prevented the eventual break of the currency pegs.

There are other motivations behind the Japanese push for an AFM, a push that has been later resurrected in the form of an initiative for closer monetary cooperation in the Asian region. For one thing, with the beginning of the European Monetary Union (EMU) and the emergence of the euro, the Japanese are concerned about the potential long-run marginalization of the yen as an international currency and the emergence of a world where the U.S. dollar and the euro are the only two major international currencies. Thus, closer monetary cooperation is one way to stimulate the development of a yen region and the international role of Japan's currency. Whether the yen is the right regional currency for Asia is not clear, however, because the patterns of trade and financial flows of the countries in the region show the western hemisphere (and Europe as well) and their currencies as major trade and financial partners. Furthermore, many Asians would prefer U.S. leadership in the region to Japan's, out of lingering historical resentment against the latter.

Asian countries and Japan have shared an aversion to purely floating exchange rates. The view of the United States Treasury after the Asian crisis, that middle regimes are unstable and that corner solutions may be better than intermediate middle regimes, has not been really accepted by Japan and other countries in the region that still see some form of managed rates as possible and desirable. Indeed, some countries in the region (Korea and Thailand) appear to have used intervention in foreign exchange markets in 1999-2000 to prevent excessive appreciation or depreciation of their currency, a move in the direction of managed exchange rates such as those prevalent before the Asian crisis. In that context, an AMF or other forms of monetary cooperation (such as the recent decision of some countries in the region to increase and extend their forex swap lines) can be seen as a way to ensure that exchange rate stability is maintained in the Asian region. In the view of some, the European Exchange Rate Mechanism (ERM) or EMU appears as a model of how Asian monetary cooperation should evolve over time.$^{89}$ But whether Asia is an optimal currency area is a com-

89. At the January 2001 meeting of the European and Asian Finance Ministers a joint French and Japanese paper was presented supporting the idea of limiting the degree of exchange rate flexibility in the Asian region; the paper argued that in some circumstances it might be appropriate for countries to peg their currencies to a basket of different currencies or seek to keep their currency within a fixed band (a target zone idea along the lines of the European monetary system). 
plex issue that has to be analyzed separately (e.g., Frankel and Wei 1993; McKinnon 2000).

\section{Global Financial Superregulator (Kaufman)}

Kaufman (Washington Post, 27 January 1998; 1998) has proposed the creation of a global superregulator: a new international institution that would regulate financial markets and institutions. This institution would supervise and regulate the activities of both traditional banks and nonbanking financial intermediaries. The logic of this proposal is that financial regulation is still at the national level, but financial institutions now operate globally, and financial markets are globally integrated. Thus, supervision solely at the national level may not be appropriate for firms that do business globally and in markets that are becoming more and more integrated internationally. Indeed, lack of global supervision and regulation may be one cause of the phenomenon of financial contagion.

There are tremendous obstacles - both political and regulatory and economic - to the idea that sovereign governments around the world would give up their right to supervise and regulate their domestic financial institutions. Also, there are issues of the accountability of such a global regulator: to whom would it be accountable and how? However, as the process of financial integration and globalization continues, the case for more coordination among national regulators is becoming more widely accepted. Indeed, the FSF was created in part as a mechanism of coordination of national regulatory policies in financial markets, in light of the international nature of many regulatory problems. Thus, although the idea of a global superregulator is farfetched, the idea of greater international coordination of national policies of supervision and regulation will gain ground, as the experience with the FSF suggests.

Also, greater integration may lead, over time, to supernational regulation of financial markets. For example, in Europe, the process of monetary and financial integration has opened the issue of whether banking supervision and regulation should be left to national monetary authorities or transferred to the European Central Bank. It is possible that the latter solution might eventually emerge.

One major obstacle to international supervision and regulation of banking systems derives from the safety net function played by national monetary authorities. Such services are provided by domestic monetary authorities only to financial institutions (be they domestic or foreign banks and their branches) that do operate within a country's borders. In exchange for this provision of a safety net (access to the discount window, LOLR liquidity support, deposit insurance, and even bailout in case of financial distress) the banking institutions subject themselves to supervision and regulation. If supervision and regulation were made by an international institution, however, who would provide the safety net to banking institutions? Moreover, if a systemic banking crisis in a country leads to significant fiscal costs 
of bailing out that financial system, who would pay the costs? In the current regime of national regulation, each country (i.e., its taxpayers) bears this cost. However, if regulation is international and if banking crises occur in spite of such regulation (or because of mistakes in such regulation), who should be bearing the fiscal costs, the domestic taxpayer or the international taxpayer? One could make a case in principle for the latter, but the political resistance to such a solution appears currently insuperable. ${ }^{90}$ These are complex and difficult questions that have no easy answer.

\section{Soros Proposal for International Deposit Insurance}

Soros (Financial Times, 31 December 1997; 1998) has proposed the creation of a public international deposit insurance agency that would insure international investors' claims against default. The logic of this proposal is to reduce the risk of self-fulfilling runs when investors panic and fail to roll over short-term claims coming to maturity. Insured claims would not be run on, as they would be safe. To reduce risk of moral hazard, Soros suggests that the amount of insurable claims of each country should be limited to a maximum, with the ceiling set by the IMF based on the soundness of a country's fundamentals. Debtor countries would pay the cost of this insurance scheme by paying an insurance fee when issuing loans, bonds, and other claims.

This proposal raises a number of issues. ${ }^{91}$ Specifically, if the insurance fee is actuarially fair and there are no informational failures, the debtor does not gain anything relative to issuing uninsured bonds. An insured bond would be riskless and have no spread relative to other riskless international bonds (say, U.S. treasuries) but the insurance fee would be equal to the spread of that country's debt relative to riskless assets. Thus, after paying the fee, the cost of external borrowing for the country would remain the same. ${ }^{92}$

Also, such schemes are usually not a free lunch. If some claims are insured, others are not. Moreover, because a country's ability to pay - that is, to service its external debt-is given (by its resources and expected future

90. For example, in the debate on dollarization, the United States has made clear that the Federal Reserve safety net would not be extended under any circumstance to the financial system of a dollarizing country and that the U.S. would not accept responsibility for the supervision and regulation of the financial system of a dollarizer. Taking control of supervision and regulation would imply accepting responsibility for problems of the financial system and would put pressure on the Federal Reserve to provide safety net services to a foreign financial system: hence the U.S. unwillingness to supervise other countries financial system. For a review of dollarization, from a faction in the U.S. Senate that wishes to encourage it, see Schuler (1999).

91. See also Eichengreen (1999a) for a thoughtful discussion.

92. If market prices are different from actuarially fair prices, the debtor may gain or lose. Differences in the relative knowledge or ignorance about fundamental risks between the debtor and market providers of insurance may be a channel through which value is created. However, one has to recur to externalities or informational failures to make such an argument. 
foreign exchange receipts), giving seniority to some insured claims means that the spread on the uninsured ones will go up, with no overall benefit for the country in terms of reduced average spread on its external debt. For the same reason, the risk of a run on uninsured claims will go up. Thus, the risk of liquidity runs might be increased rather than reduced. Also, if insurance is such a good idea, why wouldn't private markets be providing such services? Why should a public agency provide it? One needs to argue that externalities and informational asymmetries and failures are very important to derive a rationale for the public provision of such services. Such externalities and asymmetries may be important in practice, but designing an international deposit insurance scheme that is incentive-compatible and minimizes moral hazard distortions may be quite challenging.

\section{Collateral and Credit Enhancements: Creation of Value or Redistribution of Value?}

Several authors have suggested the usefulness of collateral or credit enhancements as instruments of crisis prevention and crisis resolution (Feldstein 1999b, 2000; Corrigan 2000). Indeed, various types of sweeteners and credit enhancements have been part of recent restructuring episodes.

In general, sweeteners (such as collateral and other enhancements) create different levels of formal or informal seniority among private claims that negatively affect other claims (whether private or official) that do not have the same features. Because a country's ability to pay, while uncertain, is given, there is usually no free lunch here, and provision of greater seniority to some claims comes at the cost of less seniority for other claims. ${ }^{93}$ This burden-shifting game, often at the expense of official creditors' claims, can distort debt flows. Deals in which new claims are provided collateral in the form of future exportable receipts are particularly notable and may not be legal (because they may clash with current "negative pledge clauses" in World Bank and MDB loans). They are a case of burden shifting. Milder forms of seniority upgrades (such as the sovereign taking responsibility for claims of semisovereign entities) are also examples of burden shifting. Other seniority upgrades are embedded in the fine print of the new bonds. For example, the Ecuador deal's reinstatement of the original principal (i.e., recession of the haircut on principal payments) in the case that the new bonds are restructured down the line is an example of this indirect attempt to provide seniority to the new instruments.

The arguments presented to justify such reinstatement clauses and general seniority upgrades are as follows: (a) they are necessary to maximize the chances of a successful deal; (b) it is unfair to creditors that instruments that have, as Bradies, already experienced one or more haircuts will experience another one in the future. However, there are several objections to

93. We discuss below the cases in which credit enhancements may create value. 
these views. First, investors who want to lock in the value of the new bonds (inclusive of any mark-to-market gains) can do so by selling these new bonds at current market prices; holding them over time implies accepting the credit risk (potential gains and losses) embedded in the underlying claims. Second, as long as such new instruments trade at significant spreads over risk-free assets, it means that they are not risk-free or senior relative to other instruments. If they were formally treated as effectively senior, they would trade at much lower spreads relative to risk-free rates. Third, creating degrees of grayness with some restructured claims being informally more senior (but not fully risk-free) than other private and public claims may add to the confusion and lack of transparency and predictability of the claims. Either new claims have clear collateral (as the Bradies had) and whatever seniority is embedded in them is formally agreed upon so that absolute and relative pricing of different claims can be clearly made, or, otherwise, one creates a new system of pseudo senior claims that adds to the pricing uncertainty and unpredictability of the system of debt flows to emerging markets.

More generally, some — like Corrigan (2000) — have suggested that credit enhancements and broad guarantees should be used as an alternative to large official packages of money. In principle, if one wanted to avoid large official packages and minimize the use of semicoercive PSI schemes, one could think of a world where countries, subject to a run or whose currency is under pressure, could get temporary loans from the private sectors that are guaranteed by the official sector. This, in Corrigan's view, could be a useful alternative to PSI and big official packages. It is, however, not clear whether this solution is truly different from a large official package. Conceptually, however, there is little difference between the IMF's directly borrowing from its official shareholders at risk-free rates and lending the proceeds in big packages at approximately risk-free rates to a country in crisis, and the private sector's lending the same amount of money to the country in crisis under a full guarantee of the loan.

The broader conceptual question is whether such enhancements provide any "value" to debtors beyond the direct benefit or transfer to the debtor deriving the implicit subsidy involved in the guarantee. It is not obvious that this is usually the case. Credit enhancements can create value when there is an externality or some informational asymmetry. For example, in a situation with the risk of a liquidity run, official money, either directly or indirectly through private loans that have guarantees, may improve welfare by avoiding self-fulfilling runs not justified by fundamentals (such as a run that is a clear case of a negative externality and market coordination failure). Thus, enhancements may not imply any subsidy cost to the official sector when they prevent avoidable crises. In those cases, however, the optimal choice is a large package of official money; the alternative of a fully guaranteed loan is not, in any substantial terms, different from the big official 
package. Political constraints and resistance to official money apply to the first scheme as easily as the latter.

Informational asymmetries may also create value. In general, the broad analytical literature on securitized credit (see, e.g., Klapper [2000] for a review) finds that secured loans occur at the expense of unsecured loans: pledging collateral or providing seniority to one lender subordinates the claims of other creditors. However, secured lending may have a rationale if there are informational asymmetries (if the borrower is unable to otherwise "signal" that its likelihood of defaulting is lower than the one perceived by the market and thus requires collateral for credible signaling) or other agency problems (as in the Jensen and Meckling [1976] case, in which collateral controls for the agency problem of asset substitution, i.e., borrowers substitute for riskier than for less risky assets). It is not, however, obvious that these cases systematically apply to sovereign borrowers. Specifically, signaling from the use of collateral may exacerbate the distortions from asymmetric information rather than reducing them. For example, a highly indebted sovereign who is likely and willing to default and is currently unable to borrow more may use the enhancement or collateral to receive new nondefaultable loans. But this new secured lending occurs at the expense of the previous unsecured loans, and the shift of collateral (the sovereign or country's assets) to the new loans means that, in the default state, unsecured creditors receive even less than they would have if such collateral had not been provided to the new loans.

However, apart from these very specific cases in which value is created, credit enhancements do not generally provide value either in theory or in practice. For example, take a loan that is enjoying a partial guarantee (such as a rolling interest rate guarantee in the 1999 Thailand Electricity Generating Authority of Thailand loan, one of the first cases of a formal World Bank guarantee of a semisovereign loan). Conceptually, investors will price this loan correctly; the component that is guaranteed will have a value equivalent to a risk-free loan, whereas the uncollateralized or unguaranteed part would have a "stripped" spread equal to that of other unguaranteed loans to the debtor. Thus, although the loans provide a financial benefit to the debtor, the subsidy value of the guaranteed part, there is no extra value created. The private sector could have, as well, given the debtor a loan that was not guaranteed at all, and the official sector could give the debtor a grant equal to the subsidy value of the guarantee. Generally, the guarantee cannot create extra value beyond this subsidy or transfer.

Some have argued that value can be created in these enhancements, but the arguments are not fully convincing. Specifically, the argument that is often made is that, while the guarantee is limited to only part of the cash flow (say, a rolling interest payment), the "halo" of safety of the official creditor (an MDB or the World Bank) that is providing the guarantee will fall on the entire loan; as a "pixie dust" effect, the spread on the uncollateralized com- 
ponent of the loan will also be reduced because, it is argued, it is unlikely that the debtor would want to default (and thus trigger the guarantee) on the payments that are guaranteed. However, this halo effect is most likely nonexistent in practice. First, Brady bonds did not benefit from such a halo for the uncollateralized component of their payment stream. Second, the pricing of the Thai EGAT loan suggests that the "halo effect" was miniscule: the spread on the uncollateralized part of the loan was ex-post similar to that on other nonguaranteed Thai borrowings. Thus, there is little evidence that such enhancement provided value.

Finally, there may be an indirect channel through which value is created, but if so, this is a distortionary and moral hazard-biased channel. The nonenhanced component of the loan could have a lower (stripped) spread than that on other nonguaranteed instruments only if investors truly perceived the instrument to have lower repayment or default risk than other instruments because of the official-sector "halo" on the enhanced component of the loan. If this is the case, however, the holders of the nonguaranteed part of the partially guaranteed loan benefit only because this relative seniority occurs at the expense of other creditors, those holding nonguaranteed claims. Thus, again, no real value is created: you only get a transfer of value from some creditors to others. Regimes in which such fuzzy hierarchies of seniority are created are not efficient. If relative seniority has to be provided, it is efficient if it is explicit with clear collateral or definition of the position of the asset in the pecking order of claims, not implicit and couched in "halo effects." Otherwise, incentives are distorted, transparency is reduced, and creative financial engineering is used to stake seniority.

Similar concerns can be expressed for debt-restructuring deals in which some of the cash flow payments are collateralized with some future foreign currency resources of the country (such as future oil receipts or other export receipts). Such deals do not usually increase the creditworthiness of the country because the ability - as opposed to the willingness - to pay depends on the country's debt relative to its assets, inclusive of the discounted values of any future stream of foreign currency receipts. They usually shift seniority to those creditors who get such deals at the expense of other creditors (both private unsecured or official creditors). These collateralized deals may also violate "negative pledge clauses" on World Bank and other MDB loans.

\section{Alternative Ideas for the Process of Debt Restructuring}

Many investors and creditors have expressed unhappiness with the current process of bonded debt restructurings (i.e., the model of "debt exchange offers preceded by market soundings") in spite of the success of recent restructurings based on this model (see the section on "The Role of the G3"). In their view, the current process is unfair: it does not include enough of their input, it does not allow for a meaningful negotiation with the debtor and 
official creditors on the distribution of the burden sharing, and it biases the negotiating power in favor of the debtor, thus undermining the incentives to service in full and on time debt payments. Some (for example, a group that was sponsored by the Council on Foreign Relations [CFR]) accordingly suggest that an alternative process should be followed in such restructurings based on creditor committees and more formal negotiations. ${ }^{94}$ In this alternative process, an ad hoc group of bondholders (and possibly other creditors) would be formed and a formal negotiation with the debtor would take place. Some also suggest that the negotiations should be extended to official creditors to ensure that the private sector is not a residual claimant but rather has a say in how much of the burden will be borne by private creditors compared to public creditors. To sweeten this shift in bargaining power to private creditors, it has been suggested that creditors may be willing, in exchange for formal committees and negotiations, to accept a voluntary debt standstill accompanied by a legally enforceable stay of litigation.

In contrast to this proposal, critics argue that it is not clear that, in debt exchanges, too much bargaining power is shifted to debtors. In fact, such offers are voluntary in the sense that the debtor has to offer terms that maximize the probability that a large fraction (often formally over 85 percent) of creditors accept it. Thus, if one looks at recent bond restructuring episodes (in Ukraine, Pakistan, Russia, and Ecuador) one can observe that the terms of the restructured bonds have been extremely generous and have provided significant mark-to-market gains to creditors who accepted such offers. Advisors make extensive market soundings before the offer is launched to figure out the preferences of creditors for the type, terms, and conditions of the restructured instruments. It is thus not clear that an alternative process based on formal negotiations would provide a smaller slice of the burden pie to creditors.

Second, formal negotiations with debtors run the risk of dragging on indefinitely and inflicting "delay losses" on both creditors and debtors. A situation in which debts are in default for protracted periods of time is highly disruptive to debtors as cutoff from market access, output losses, and other real costs accumulate over time. Such losses eventually hurt the debtor's ability to pay and are thus costly to creditors as well.

94. This is a different group from the task force that, under the CFR umbrella, proposed a framework for the reform of the international financial architecture. For reasons of space, we do not discuss the proposals of this group presented in a report (Independent Task Force 1999). These proposals are conceptually in between the radical reforms of the Meltzer Commission and the gradualist changes agreed upon by the G7 and the IMF. For example, the CFR suggests a smaller use of large IMF packages and a greater reliance on more coercive forms of PSI, but it does not go as far as the Meltzer Commission in restricting the ability of the IMF to provide lending in crisis episodes. Also, the CFR task force expressed some sympathy for a more structured restructuring process (creditor committees, negotiations, and collective action clauses) that is consistent with some of the views of the other CFR group initiative discussed in the text. 
Third, there are serious obstacles and disadvantages to the idea that creditors could be involved in the decision on how much adjustment the debtor would make, how much official multilateral support would be provided, and how much of the sharing burden would be borne by the PC creditors. ${ }^{95}$

Fourth, bilateral market soundings between debtors and creditors appear to have worked satisfactorily in Pakistan, Ukraine, and Russia. If anything the experience of the Ecuador Consultative Group in which the debtor regularly met with a broad representation of bondholders has been criticized as unproductive and unsuccessful. It became, at times, an unconstructive forum where frustrated creditors vented their unhappiness with the slowness of the adjustment and restructuring process rather than a productive procedure to accelerate the restructuring. Sometimes bilateral soundings are more efficient than large public forums where both sides posture to stake their claims.

Fifth, it is not obvious that one restructuring process provides more incentive for strategic nonpayments or defaults than another. In the debt exchange offer model, the debtors are usually wary of stopping payments to private creditors and would rather avoid nonpayment for as long as possible because the economic (and legal) costs of such a formal default can be very high: loss of output, loss of market access, trade sanctions, and so on. It is not clear why a formal negotiating process (especially one in which standstills are sanctioned and stays of litigation imposed) would provide lower bargaining power to the debtor. It is ambiguous in theory and in practice whether either process has a systematic effect on the relative bargaining power of debtors versus creditors. Indeed, some processes that would lead to delay in negotiations may be negative-sum games in which inefficient costs of delay impose welfare losses on both debtors and creditors. Thus, a system of debt exchange with market soundings may be beneficial to all.

In conclusion, it is not obvious that an alternative process based on negotiations and formal creditor committees would be in the interest of creditors. ${ }^{96}$ It would certainly be worthwhile, however, to study alternative process schemes and improve on existing ones. For example, the current system of "market soundings" has been somewhat unstructured. Maybe a more structured process would contribute to providing financial advisors with the information necessary to design successful debt exchanges. Also, although negotiations between private and official creditors are not likely to

95. See Roubini (2000) for a detailed discussion of these objections. In general, most privatesector participants agree that their involvement in the first two steps, design of macro policy adjustment effort and amount of multilateral support, is not likely to occur; but they would like to be involved in the last step, the discussion of the relative role of official bilateral creditors (PC) and the private sector in burden sharing and a direct negotiation with the debtor on the terms of a restructuring.

96. However, the official sector remains open to the idea that creditors' committees and negotiations between creditors and debtors may be at times an appropriate mechanism to restructure sovereign bonded debt liabilities; see Geithner (2000). 
occur, there may be ways to improve the flow of information to the private sector. Official creditors could be more clear about the PSI doctrine and its application; the PC could become somewhat more transparent and better explain its procedures and terms for restructuring; ${ }^{97}$ the debtor country should provide information to creditors in good and bad times and keep them fully informed of economic prospects, external debt and payment stream data, economic forecasts, and possible external financing problems and plans to address these problems; and the IMF could have a closer dialogue with the private sector and more regularly brief investors on program developments for a debtor country with external debt-servicing problems. All these steps would increase transparency, openness, and predictability of PSI and reduce the impression that the process is arbitrary and unpredictable. Constructive ideas along these lines could improve the current system and support the cooperative goals of the PSI policy.

\subsubsection{Conclusions}

The emerging market countries might have reacted to the crises they suffered in the late 1990s by challenging the legitimacy of the world financial system, charging that it was rigged to benefit rich-country investors. For the most part this has not happened. True, they complain that they deserve better representation in the governance structure than they have received in the past. True, the crises made it more difficult to claim that free financial markets operate with perfect efficiency. True, improvements in the system are both desirable and possible. Nevertheless, most countries everywhere now agree that a global capitalist system best promotes growth. Furthermore, few can deny the practical realities that give heavy weight to the United States and other $\mathrm{G} 7$ countries as a steering committee in the governance of that system - the logistical advantages of small numbers and the power dynamics of creditor-debtor relationships.

This chapter has reviewed the role of the major industrialized countries in three areas: (a) their own macroeconomic policies, which determine the global financial environment; (b) their role in responding to crises when they occur, particularly through rescue packages with three componentsreforms in debtor countries, public funds from creditor countries, and PSI; and (c) efforts to reform the international financial architecture, with the aim of lessening the frequency and severity of future crises. The latter two topics are closely intertwined, due to tension between mitigating crises in the short run and the moral hazard that rescues create in the longer term.

The phrase "new Bretton Woods," or even "new financial architecture," may be too grand to connote the reform initiatives that have been under-

97. The PC has indeed recently opened a website [http://www.clubdeparis.org/] where information is provided to investors about its activities, rules, procedures, and decisions. 
taken for the future. These reforms are modest and incrementalist, rather than sweeping and revolutionary - perhaps more like redoing the plumbing and electricity in the house than redesigning the architecture from the ground up. However, they may nonetheless contribute to crisis prevention and resolution. If all the PSI reforms are successfully implemented, crises when they occur may be better managed and resolved at lower costs. If all the crisis prevention reforms are successfully implemented, the system may become less prone to crises in the first place. This will take years. It would be foolish to think that reforms already in progress will eliminate the risk of crises in emerging markets. Some degree of volatility is inevitable - perhaps even a higher degree of volatility at early stages of a poor country's liberalization and industrialization than would prevail if it remained economically isolated and undeveloped. The United States had severe financial and economic crashes during its period of industrialization. Perhaps the rest of the world will settle down to a stable and tranquil path only when its markets and institutions are as well developed as those of the United States today.

\section{References}

Bagci, Pinar, and William Perraudin. 1997. The impact of IMF programmes. Institute for Financial Research Working Paper no. 35. London: Birkbeck College, February.

Bhagwati, Jagdish. 1998. Fifty years: Looking back, looking forward. Paper presented at the Symposium on the World Trading System. 30 April, Geneva, Switzerland.

Becker, Torbjorn, Anthony J. Richards, and Yungong Thaicharoen. 2000. Collective action clauses for emerging market bonds: Good news for lower rated borrowers too. Washington, D.C.: International Monetary Fund. Unpublished manuscript.

Bergsten, C. Fred. 2000. Minority dissent on the Report of the International Financial Institution Advisory Commission ("Meltzer Commission"). Washington, D.C.: Institute of International Economics.

Bird, Graham, and Dane Rowlands. 1997. The catalytic effects of lending by the international financial institutions. World Economy 20 (7): 967-91.

Bordo, Michael D., and Anna J. Schwartz. 2000. Measuring real economic effects of bailouts: Historical perspectives on how countries in financial distress have fared with and without bailouts. NBER Working Paper no. 7701. Cambridge, Mass.: National Bureau of Economic Research, May.

Bucheit, Lee, and G. Mitu Gulati. 2000. Exit consents in sovereign bond exchanges. UCLA Law Review 48 (October): 59-84.

Calomiris, Charles. 1998a. Blueprints for a new global financial architecture. Columbia University, Graduate School of Business. Unpublished manuscript. $275-95$.

Calvo, Guillermo, Leonardo Leiderman, and Carmen Reinhart. 1993. Capital in- 
flows and real exchange rate appreciation in Latin America: The role of external factors. IMF Staff Papers 40 (March): 108-50.

1994. The capital inflows problem: Concepts and issues. Contemporary Economic Policy 12 (July): 54-66.

Chinn, Menzie D., Michael P. Dooley, and Sona Shrestha. 1999. Latin America and East Asia in the context of an insurance model of currency crises. NBER Working Paper no. W7091. Cambridge, Mass.: National Bureau of Economic Research, April.

Chuhan, Punam, Stijn Claessens, and Nlandu Mamingi. 1998. Equity and bond flows to Latin America and Asia: The role of global and country factors. Journal of Development Economics 55:439-63.

Clarida, Richard. 2000. G3 exchange rate relationships: A recap of the record and a review of proposals for change. Essays in International Economics no. 219. Princeton, N.J.: Princeton University Press.

Cline, William. 1984. International debt: Systemic risk and policy response. Washington, D.C.: Institute for International Economics.

. 1995. International debt reexamined. Washington, D.C.: Institute for International Economics.

-2000. The role of the private sector in resolving financial crises in emerging markets. Washington, D.C.: Institute of International Finance. Mimeograph, October.

Conway, Patrick. 1994. IMF lending programs: Participation and impact. Journal of Development Economics 45 (December): 365-91.

Corrigan, E. Gerald. 2000. Two international financial stability issues: Asset price inflation and private sector participation in financial crisis stabilisation. Financial Stability Review (June): 136-41.

Corsetti, Giancarlo, Paolo Pesenti, and Nouriel Roubini. 1999a. Paper tigers? A model of the Asian crisis. European Economic Review 43 (July): 1211-36.

1999b. What caused the Asian currency and financial crisis? Japan and the World Economy 11 (September): 305-73.

. 2001. The role of large players in currency crises. NBER Working Paper no. 8303. Cambridge, Mass.: National Bureau of Economic Research, May.

Council on Foreign Relations. 1999. Safeguarding prosperity in a global financial system: The future international financial architecture. Washington, D.C.: Institute for International Economics.

Dallara, Charles. 1999. Letter to the chairman of the Interim Committee. Available at [http://www.iif.com]. 16 September.

de Brouwer, Gordon. 2000. Improving the bureaucracy of international economic cooperation. Australian National University.

De Gregorio, José, Barry Eichengreen, Takatoshi Ito, and Charles Wyplosz. 1999. An independent and accountable IMF. In Geneva report on the world economy. London: Centre for Economic Policy Research.

Dell'Ariccia, Giovanni, Isabel Goedde, and Jeromin Zettelmeyer. 2000. Moral hazard in international crisis lending: A test. Washington, D.C.: International Monetary Fund. Manuscript, November.

Diaz-Alejandro, Carlos. 1985. Good-bye financial repression, hello financial crash. Journal of Development Economics 19:1-24.

Dicks-Mireaux, Louis, Mauro Mecagni, and Susan Schadler. 1997. Evaluating the effect of IMF lending to low-income countries. Washington, D.C.: International Monetary Fund, Unpublished manuscript.

Dominguez, Kathryn, and Jeffrey Frankel. 1993. Does foreign exchange intervention work? Washington, D.C.: Institute for International Economics. 
Dooley, Michael. 2000a. Can output losses following international financial crises be avoided? NBER Working Paper no. 7531. Cambridge, Mass.: National Bureau of Economic Research, February. 256-72.

2000b. A model of crises in emerging markets. Economic Journal 110 (460):

Dooley, Michael, Eduardo Fernandez-Arias, and Kenneth Kletzer. 1994. Recent private capital inflows to developing countries: Is the debt crisis history? NBER Working Paper no. 4792. Cambridge, Mass.: National Bureau of Economic Research, July.

Dornbusch, Rudiger. 1985. Policy and performance links between LDC debtors and industrial nations. Brookings Papers on Economic Activity, Issue no. 2:303-56. Washington, D.C.: Brookings Institution.

Eichengreen, Barry. 1999a. Toward a new financial architecture: A practical post-Asia agenda. Washington, D.C.: Institute for International Economics.

- 1999b. Is greater private-sector burden sharing impossible? University of California, Berkeley, Department of Economics. Manuscript, May.

. 2000. Can the moral hazard caused by IMF bailouts be reduced? Geneva Reports on the World Economy, Special Report no. 1. Geneva: International Center for Monetary and Banking Studies.

Eichengreen, Barry, and Ashoka Mody. 2000a. Would collective action clauses raise borrowing costs? NBER Working Paper no. 7458. Cambridge, Mass.: National Bureau of Economic Research. January.

2000b. Would collective action clauses raise borrowing costs? An Update and Additional Results. Policy Research Working Paper no. 2363. Washington, D.C.: World Bank, June.

Eichengreen, Barry, and Richard Portes. 1995. Crisis? What crisis? Orderly workouts for sovereign debtors. London: Center for Economic Policy Research.

Eichengreen, Barry, and Andrew Rose. 2001. Staying afloat when the wind shifts: External factors and emerging market banking crises. In Money, Factor Mobility, and Trade: Essays in Honor of Robert Mundell, ed. Guillermo Calvo, Rudiger Dornbusch, and Maurice Obstfeld, 171-205. Cambridge: Massachusetts Institute of Technology Press.

Eichengreen, Barry, and Christof Ruhel. 2000. The bail-in problem: Systematic goals, ad hoc means. NBER Working Paper no. W7653. Cambridge, Mass.: National Bureau of Economic Research. April.

Feldstein, Martin. 1994. American economic policy in the 1980s: A personal view. In American economic policy in the 1980s, ed. Martin Feldstein, 1-79. Chicago: University of Chicago Press.

- 1999a. Refocusing the IMF. Foreign Affairs 78 (2): 93-109.

1999b. Self-protection for emerging market economies. NBER Working Paper no. 6907. Cambridge, Mass.: National Bureau of Economic Research, January.

2000. Aspects of global economic integration: Outlook for the future. NBER Working Paper no. 7899. Cambridge, Mass.: National Bureau of Economic Research, September.

Fernandez-Arias, Eduardo. 1994. The new wave of private capital inflows: Push or pull? World Bank Policy Research Working Paper no. 1312. Washington, D.C.: World Bank, Debt and International Finance Division, International Economics Department, June.

Fischer, Stanley. 1999. Learning the lessons of financial crises: The roles of the public and private sectors. Speech to the Emerging Market Traders' Association Annual Meeting. 9 December, New York. Available at [http://www.imf.org/external/np/speeches/1999/120999.HTM]. 
2000. Managing the international monetary system. Address given at the International Law Association Biennial Conference. 26 July, London.

Fischer, Bernhard, and Helmut Reisen. 1994. Pension fund investment from aging to emerging markets. OECD Development Centre Policy Brief no. 9. Paris: Organization for Economic Cooperation and Development.

Frankel, Jeffrey. 1999. No single currency regime is right for all countries or at all times. Essays in International Finance no. 215. Princeton, N.J.: Princeton University Press.

Frankel, Jeffrey, and Chudozie Okongwu. 1996. Liberalized portfolio capital inflows in emerging markets: Sterilization, expectations, and the incompleteness of interest rate convergence. International Journal of Finance and Economics 1 (1): $1-23$.

Frankel, Jeffrey, and David Romer. 1999. Does trade cause growth? American Economic Review 89 (3): 379-99.

Frankel, Jeffrey, and Andrew Rose. 1996. Currency crashes in emerging markets: An empirical treatment. Journal of International Economics 41 (3/4): 351-66.

Frankel, Jeffrey, and Shang-Jin Wei. 1993. Is Japan creating a yen bloc in East Asia and the Pacific? In Regionalism and rivalry: Japan and the U.S. in Pacific Asia, ed. Jeffrey Frankel and Miles Kahler, 53-85. Chicago: University of Chicago Press.

Friedman, Benjamin. 2000. How easy should debt restructuring be? In Managing financial and corporate distress: Lessons from Asia, ed. Charles Adams, Robert Litan, and Michael Pomerleano, 21-46. Washington, D.C.: Brookings Institution.

Geithner, Timothy. 2000. Resolving financial crises in emerging market economics. Remarks before the Securities Industry Association and Emerging Markets Trades Association. 23 October, New York, N.Y.

Giannini, Curzio. 1999. Enemy of none but a common friend of all: An international perspective on the lender-of-last-resort function. Essays in International Finance, no. 21. Princeton, N.J.: Princeton University Press.

Goldstein, Morris. 1997. The case for an international banking standard. Policy Analyses in International Economics no. 47. Washington, D.C.: Institute for International Economics.

Goldstein, Morris, Graciela Kaminsky, and Carmen Reinhart. 2000. Assessing financial vulnerability: An early warning system for emerging markets. Washington, D.C.: Institute for International Economics.

Goldstein, Morris, and Mohsin Khan. 1985. Income and price effects in foreign trade. In Handbook of International Economics, vol. 2, ed. R. Jones and Peter B. Kenen, 1041-105. Amsterdam: Elsevier.

Group of Seven (G7). 1999. Strengthening the international financial architecture. Washington, D.C.: G7.

. 2000. Strengthening the international financial architecture. Report from G7 Finance Ministers to the Heads of State and Government. 21 July, KyushuOkinawa, Japan.

Haldane, Andy. 1999. Private sector involvement in financial crisis: Analytics and public policy approaches. Bank of England Financial Stability Review (November): $184-202$.

Haque, Nadeem U1, and Mohsin Khan. 1999. Do IMF-supported programs work? A survey of the cross-country empirical evidence. IMF Working Paper no. WP/98/169. Washington, D.C.: International Monetary Fund, December.

Henning, C. Randall. 1999. The exchange stabilization fund: Slush money or war chest? Policy Analyses in International Economics no. 57. Washington, D.C.: Institute for International Economics.

Independent Task Force. 1999. Safeguarding prosperity in a global financial sys- 
tem: The future international financial architecture. Report of an Independent Task Force sponsored by the Council on Foreign Relations. New York: Council on Foreign Relations.

Institute of International Finance (IIF). 1999a. Global private finance leaders stress the importance of voluntary approaches to crisis resolution in emerging markets. Available at [http://www.iif.com/PressRel/1999pr9.html]. 24 June.

. 1999b. Summary report on the work of the IIF steering committee on emerging markets finance. Washington, D.C.: IIF.

1999c. Testing for "moral hazard" in emerging markets lending. IIF Research Papers no. 99-1. Washington, D.C.: IIF, August.

International Financial Institution Advisory Commission (IFIAC). 2000. Report of the International Financial Institution Advisory Commission ("Meltzer Commission"). Washington, D.C.: IFIAC.

International Monetary Fund (IMF). Various issues. Direction of trade. Washington, D.C.: IMF.

Various years. International financial statistics. Washington, D.C.: IMF.

Various years. World economic outlook. Washington, D.C.: IMF.

1999. Involving the private sector in forestalling and resolving financial crises. Washington, D.C.: IMF, Policy Development and Review Department, April.

_. 2000a. International capital markets: Developments, prospects, and key policy issues. World Economic and Financial Surveys. Washington, D.C.: IMF, September.

2000b. Involving the private sector in the resolution of financial crises: Standstills, preliminary considerations. Washington, D.C.: Policy Development and Review Department and Legal Department, September.

. 2000c. Report to the IMF executive board of the Quota Formula Review Group. Washington, D.C.: IMF, April.

Jensen, Michael, and William Meckling. 1976. Theory of the firm: Managerial behavior, agency costs, and ownership structure. Journal of Financial Economics 3: 305-60.

Kahn, Robert. 2000. The role of the private sector in the prevention and resolution of international financial crises. Paper presented at the Conference on the Governance of the Global Capital Market. 23 October, Montreal.

Kaufman, Henry. 1998. Proposal for improving the structure of financial supervision and regulation. Remarks before the Brookings Institution Symposium on Limiting Moral Hazard in Financial Rescues. 4 June, Washington, D.C.

Kenen, Peter. 2001. The international financial architecture: What's new? What's missing? Washington, D.C.: Institute for International Economics.

King, Mervyn. 1999. Reforming the international financial system: The middle way. Speech delivered to a session of the money marketeers at the Federal Reserve Bank of New York. 9 September.

Klapper, Leora. 2000. The uniqueness of short-term collateralization. World Bank Working Paper no. 2544. Washington, D.C.: World Bank.

Köhler, Horst. 2000. Toward a more focused IMF. Address to International Monetary Conference. 30 May, Paris, France. Available at [http://www.imf.org/external/np/speeches/2000/053000.htm].

Krueger, Anne. 1997. Whither the World Bank and the IMF? NBER Working Paper no. 6327. Cambridge, Mass.: National Bureau of Economic Research, December.

Lane, Timothy, and Steven Phillips. 2000. Does IMF financing result in moral hazard? IMF Working Paper no. WP/00/168. Washington, D.C.: International Monetary Fund, October. 
Levinson, Jerome. 2000. Dissent on the report of the International Financial Institution Advisory Commission ("Meltzer Commission"). Washington, D.C.

McKibbin, Warwick, and Jeffrey Sachs. 1988. Coordination of monetary and fiscal policies in the industrial economies. In International aspects of fiscal policies, ed. Jacob Frenkel, 73-120. Chicago: University of Chicago Press.

1991. Global linkages: Macroeconomic interdependence and cooperation in the world economy. Washington, D.C.: Brookings Institution.

McKinnon, Ronald. 2000. After the crisis, the East Asian dollar standard resurrected. Stanford University, Department of Economics. Manuscript, August.

McKinnon, Ronald, and Huw Pill. 1997. Credible economic liberalizations and overborrowing. American Economic Review Papers and Proceedings 87: 189-93.

McQuillan, Lawrence, and Peter Montgomery, eds. 1999. The International Monetary Fund: Financial medic to the world? Stanford, Calif.: Hoover Press.

Meltzer, Allan. 1998. Asian problems and the IMF. Testimony prepared for the Joint Economic Committee, U.S. Congress. 24 February, Washington, D.C.

Mody, Ashok, Mark Taylor, and Jung Yeon Kim. 2001. Modelling fundamentals for forecasting capital flows to emerging markets. International Journal of Finance and Economics 6 (3): 201-16.

Niehans, Jurg. 1976. How to fill an empty shell. American Economic Review Papers and Proceedings 66 (2): 177-83.

Petas, Peter, and Rashique Rahman. 1999. Sovereign bonds: Legal aspects that affect-Default and recovery. Global emerging markets: Debt strategy. London: Deutsche Bank.

Portes, Richard. 2000. Sovereign debt restructuring: The role of institutions for collective action. London Business School. Mimeograph, March.

Prusa, Thomas. 2000. On the spread and impact of antidumping. NBER Working Paper no. 7404. Cambridge, Mass.: National Bureau of Economic Research.

Rogoff, Kenneth. 1999. International institutions for reducing global financial instability. Journal of Economic Perspectives 13 (4): 21-42.

Roubini, Nouriel. 2000. Bail-in, burden-sharing, private sector involvement (PSI) in crisis resolution and constructive engagement of the private sector. A primer: Evolving definitions, doctrine, practice, and case law. New York University, Stern School of Business. Unpublished manuscript.

Rubin, Robert. 1998. Strengthening the architecture of the international financial system. Remarks to the Brookings Institution, 14 April.

Sachs, Jeffrey. 1985. The dollar and the policy mix: 1985. Brookings Papers on Economic Activity, Issue no. 1:117-97. Washington, D.C.: Brookings Institution.

1995. Do we need an international lender of last resort? Frank D. Graham lecture at Princeton University. 20 April. Available at [http://www2.cid.harvard. edu/cidpapers/intllr.pdf].

Schott, Jeffrey. 1998. The World Trade Organization: Progress to date and the road ahead. In Launching new global trade talks: An action agenda, ed. Jeffrey Schott, 3-24. Washington, D.C.: Institute for International Economics.

Schuler, Kurt. 1999. Basics of dollarization. Joint Economic Committee Staff Report, U.S. Congress. January (updated January 2000).

Schultz, George, William Simon, and Walter Wriston. 1998. Who needs the IMF? In The International Monetary Fund: Financial Medic to the World? ed. Lawrence McQuillan and Peter Montgomery, 197-200. Stanford, Calif.: Hoover Press. First published in Wall Street Journal, 3 February 1998.

Schwartz, Anna. 1998. Time to terminate the ESF and the IMF. Cato Institute Foreign Policy Briefing, no. 48, August, Washington, D.C.: Cato Institute.

Soros, George. 1998. The crisis of global capitalism. New York: Public Affairs Press. 
Subramanian, Arvind. 1999. Intellectual property rights. Proceedings from Conference on Developing Countries and the New Round of Multilateral Trade Negotiations. 5-6 November, Harvard University.

Summers, Lawrence. 1999. The right kind of IMF for a stable global financial system. Paper presented to the London School of Business. 13 December. Available at [http://www.ustreas.gov/press/releases/ps294.htm].

- 2000. International financial crises: Causes, prevention, and cures. American Economic Review 90 (May): 1-16.

U.S. Treasury. 2000. Response to the report of the International Financial Institution Advisory Commission. Washington, D.C.: United States Treasury Department, June.

Waldman, Michael. 2000. POTUS speaks. New York: Simon and Schuster.

Wang, Zhen Kun, and L. Alan Winters. 2000. Putting "Humpty" together again: Including developing countries in a consensus for the WTO. CEPR Policy Paper no. 4. London: Centre for Economic Policy Research.

Woodward, Bob. 2000. Maestro: Greenspan's Fed and the American boom. New York: Simon and Schuster.

Zettelmeyer, Jeromin. 2000. Can official crisis lending be counter-productive in the short run? Economic Notes 29 (February): 13-29.

\section{Mervyn King}

I am delighted to have this opportunity to comment on what can be done to reduce the risk of financial and currency crises and how to resolve those crises when they do occur. At the outset, I want to say that the large financial packages made available by the IMF in recent years cannot continue. They undermine the incentives of lenders to assess risks.

In addition, there is little political support among the major contributors to act as an effective lender of last resort. If you look at what countries have actually done-if you look at the attitude of the U.S. Congress and of the Group of Seven (G7) - there is no serious willingness to continue to put up large amounts of money on the scale of the packages seen in the late 1990s. Since there are de facto limits on official finance, we need a mechanism to enable countries to reschedule their sovereign debt payments where they are unwilling or unable to meet their liabilities, just as we have bankruptcy arrangements in domestic credit markets. We need a timeout mechanism of some kind to enable debtor countries to discuss a rescheduling - which may well involve no reduction in the present value of payments with their creditors.

First, however, I would like to discuss measures to prevent crises. Progress has been made in this area. There are, perhaps, six lessons for emerging markets from recent experience. The first is the desirability of policies that make equity investment more attractive, rather than a reliance on short-term debt finance. It is debt finance that creates the risk of financial crises. 
The second is the need for self-insurance. One of the lessons that I think countries have learned is that if there is no international lender of last resort, then they must create their own by building up very large foreign exchange reserves. China now has over $\$ 160$ billion of reserves; Korea has increased its reserves from $\$ 7$ billion to over $\$ 90$ billion. Now, there may be moral hazard involved, as was suggested this morning, in the existence of those reserves, but I still think you cannot blame countries for creating those reserves, given the cost to them of having to deal with rapid, shortterm reversals of capital flows. At the multilateral level, we have put in place the International Monetary Fund (IMF) contingent credit line.

The third lesson is to monitor and manage the national balance sheet. This is perhaps the single most important analytical lesson of recent crises. It might be possible to devise some simple guidelines, such as ensuring that foreign exchange reserves are sufficient to meet liabilities over at least a oneyear horizon. To eliminate the incentives to short-term capital flows requires not only measures in emerging markets but also measures in developed countries. Our own banking systems, and the implicit support we give to them, have created incentives for capital outflows to take the form of short-term debt finance.

Fourth, I think transparency is extremely important. A massive amount of work has in fact been done, and I think we should congratulate the IMF on progress in the difficult, and somewhat less glamorous, task of converting the agreements on transparency into practice. There are now some sixty-six standards and codes that have been developed, and these are being monitored. I do think, however, that there is one key point that is in danger of getting lost, namely, that transparency itself should not be compulsory. There should be no attempt to tell emerging markets that they should or should not follow a particular code. What is crucial, however, is that everyone should know whether or not a country is following a particular code. Therefore there should be transparency about transparency. That is the real role of the reports on standards and codes, the so-called ROSCs, which are now being implemented by the IMF. The heart of the surveillance process feeding into Article IV assessments would be these ROSCs and information about the degree of transparency about transparency.

Fifth, painful lessons have been learned in the area of relations with creditors. I think collective action clauses have a role to play, but the key is for debtor countries to work actively on their relations with creditors.

Finally, avoid fixed but adjustable exchange rate pegs. Many of these lessons are obvious, but they were ignored in recent years. Now they are widely accepted.

Where we have made much less progress is in crisis resolution. The two key principles here are the following. First, there are limits to official finance. There is no international lender of last resort. The choice is between either an orderly or disorderly process to reschedule payments. We need to 
think about this in advance and create some presumptions about an orderly process. Second, we need to give the private sector more clarity about exactly how the international community thinks about the principles that will guide it in dealing with crises.

Until the recent Fund annual meetings in Prague, there was a danger that this issue would not be addressed. If I may quote from the paper by Frankel and Roubini, they say, "the basic tension between the desire to limit official finance and the goal of having constructive and voluntary forms of PSI [private-sector involvement] has not been fully resolved in official doctrine and practice," and then in a footnote they say, "there is still a lot of room for fleshing out the G7 views on liquidity and systemic cases." How right they are. And I think until recently one could view official responses as lying on a spectrum between two extreme cases. One was to say that policy should be ad hoc, with each country treated on a purely case-by-case basis. The other was to say that we must have private-sector involvement and when asked to define private-sector involvement to respond by repeating the mantra over and over again. Following Prague, the G7 is now committed to discussing more fully what it means by private-sector involvement and to providing greater clarity to the private sector. These are significant steps forward.

What is needed is a regime of "constrained discretion," to use the phrase that has been applied to monetary policy. The question in coming months is how we are going to make this operational.

We will need to define more carefully what are the ex ante criteria for exceptional lending. Exceptional lending should not be frequent. There ought to be presumptions about the scale of IMF facilities. One useful idea might be to ask the new Independent Evaluation Office of the Fund to conduct an ex post audit in all cases of exceptional lending.

Second, we will need to spell out more clearly the nature of any timeout mechanism, including, if necessary, standstills. This is discussed in a very good paragraph of the Frankel-Roubini paper. I commend it to you; I won't go through those arguments, but they do suggest that any solution is likely to involve both the IMF and the private sector. We will need to give a clearer idea to the private sector about the scale of facilities that they should expect the Fund to provide to countries in difficulty. This is not a new issue. In the discussion leading up to the Bretton Woods meetings, a British representative wrote to the War Cabinet in February 1944, "in the course of discussion, the American representatives were persuaded of giving member countries as much certainty as possible about what they had to expect from the new institution and about the amount of facilities which would be at their full disposal." I also found very helpful a quotation from the briefing pack that the U.S. Treasury produced in 1944 after Bretton Woods. On page 83 of that document appears the statement, "it would be quite erroneous to assume that in the absence of the Fund, countries could permit uncontrolled 
capital outflow of any character at all times." So these issues were ones that people were aware of, but on which, until recently, discussion had lapsed.

Finally, on the governance of the international financial system, some have been tempted to ask, "do we need a new Bretton Woods?" The answer is clearly "no." As one of the U.K. representatives to Bretton Woods wrote, "the conference has become a madhouse. The most complete confusion now prevails." Moreover, in the Bank of England files, I found the most extraordinary report from a representative of the Bank of England to one of my predecessors. He wrote, "It has been an interesting experience to get onto friendly terms with the American press, but I think I've been reasonably successful. It has meant quite a considerable amount of hard drinking. Some little time ago a Miss Sylvia Porter wrote a number of scurrilous little articles about the BIS [Bank for International Settlements] and the governor of the Bank of England, and to my surprise I found that she was here as a representative of the New York Evening Post. I thought it my duty to make much of her, and succeeded fairly well, when I got a note from the New York Times man saying that she is known as Sylvia Hotpants." Naturally, the Bank of England official exercised constrained discretion. And that is surely the way to go. We need a framework of presumptive limits on IMF facilities that would provide greater clarity to debtors and creditors alike and make clear that debtors will need to negotiate with their creditors rather than asking for a bailout from the IMF. I am pleased that the IMF is committed to making progress on this subject.

\section{Robert Rubin}

What I would like to do is express a few views on a variety of subjects. I'm going to be much less organized than Mervyn King was and cover perhaps some broader ground in a much less systematic fashion. Let me also say that these are my views, and now that I'm finally out of the U.S. Treasury, I'm free to say what I want to say, and nobody should feel that people from the treasury identify with any of my views. Let me start by saying that this whole issue of crisis response, crisis management, and crisis prevention is enormously complicated. I read this whole paper, by the way, all 100 pages, and I thought it was very interesting; I thought in many ways it captured the debate and discussion we had at the treasury during the time that I was there. But it did strike me as I was reading it that however one may conceptualize about these issues, the fact is that when you are actually involved in having to deal with them, the reality is rather messy, and a lot of the conceptual constructs that one might think about from a greater remove lose a lot of their value once you actually have to deal with real situations. 
In terms of crisis prevention, although clearly all these crises were a function of many factors within the developing countries, my own view-and I don't think this was a view widely shared at the treasury when I was therewas that they were at least equally due to excesses in capital flows from industrial-country financial institutions, whether as interbank lending or as investment. Moreover, having spent twenty-six years running trading operations, I think that there is an inherent tendency in markets to go to excess when times are good, that people reach for yield, and that there's an underweighting of risk and overestimation of the positive. I think there is an inherent tendency in markets to produce crisis, and when one focuses on what one does about crisis prevention, I at least would start from the question of whether there is any way to induce greater discipline and greater rigor on the part of those who provide interbank credit and those who invest in developing countries. I remember when the Korean crisis first became serious, calling people at a couple of the banks that had been extending credit to Korea, and it was absolutely astounding to me how little they knew about the country to which they had extended credit. I thought about that a little bit, and it reminded me of a lot of the experience I'd had when I was still on Wall Street. When times are good, people reach, and when they reach, sooner or later it leads to excesses, and excesses sooner or later lead to trouble. Transparency is useful, and, trying to put in place the kinds of things that I know we were talking about at the time I left the treasury and I gather have advanced since then is useful. To increase transparency in developing countries is very helpful, but if it's not used with discipline and rigor, it's not going to have the effect that is sought. Therefore, I think it would be exceedingly useful to try to think of ways to induce greater discipline and rigor on the part of those who extend credit and the part of those who invest. I believe in capital requirements for banks and I believe in margin requirement for investors, because I think they have at least some effect in terms of inducing people to focus on risk. I think we need to go far further, although I have no concrete suggestions to make, and it is a subject I've thought about. The process of trying to find devices that you think would actually induce greater rigor is, I think, a very difficult one. One of them is obviously greater disclosure on the part of the banks that extend credit and the investment institutions that invest. However, in the financial markets in the United States we have pretty highly developed disclosure on the part of banks and investors and all the rest; nevertheless, we have recurring crises that come either out of the banking system or out of overreaction to markets.

All of which suggests to me that it is very important to try to find further measures with respect to inducing discipline, but it's going to be very difficult to find them. The other thing I think we need to do is limit leverage, because I don't think we will ever find ways of inducing discipline and rigor that are anything even remotely close to a perfect system, so the answer to that is to limit leverage. 
Let me go to a second subject: the question of private-sector involvement versus official-sector involvement versus reform. I thought the paper captured very well the kinds of debates that we used to have at the treasury and at the Federal Reserve. My own conclusion is roughly the conclusion of the paper, which is that some rough balance among them, on a case-by-case basis, is probably about the right place to be. I also think, as I said a moment ago, that people have conceptual models of all kinds, but once you get into the messy reality of dealing with actual crises, I think they lose most of their value. We used to have debates sometimes over whether something was an insolvency situation or liquidity problem. My personal view, although I don't think this was shared by everybody at the treasury, is that those two terms are approximately useless. I don't mean they're useless if you want to have interesting discussions; I just mean they're useless when you actually have to do something.

I think basically what you have is countries that are in trouble. Every country has all kinds of problems, including the United States. I remember a treasury official once saying that Brazil looked wonderful at one point, and then once it started to have problems, we all started to say, gee, there were a lot of problems. And there are plenty of problems in the United States. If we had a crisis tomorrow, people would say to us, look at their current account, personal saving rate, and a whole bunch of other things. So I think that basically what you've got to do is make a practical judgment in each case, on a case-by-case basis. And I don't agree that providing more certainty to the private sector is a step forward. I actually think it is a step backward. I think that in each one of these situations you're dealing with a very difficult question of how to restore confidence in the short run in order to stem a crisis, and confidence is obviously a psychological factor, and the psychology of markets is a messy, difficult, judgmental kind of matter. I think there are lessons we can learn that can help us think about the future, but I do think as a general matter you've got to make a practical judgment given the circumstances in each particular case.

I do believe very strongly that there should be some kind of presumption in favor of significant private-sector involvement because I think moral hazard is a very real issue. I remember during the Russian crisis when people were buying bonds at 50 and 60 and 70 percent yields, and I called a friend of mine at Wall Street and asked what people were doing. He said, well, everybody figures the International Monetary Fund (IMF) will bail them out because they've got 7000, 12,000, or whatever it was nuclear warheads, and I think it's the way people think - it's the way I would think, and I think that the answer to that is to make sure that people, based on their past experience, have an expectation that if there's trouble, they're going to have to pay part of the price.

Securitization obviously creates a whole set of new issues. Exchange offers have worked to a certain extent, or maybe even reasonably well, but 
my instinct is that the kinds of exchange offers that are available without a cram-down provision are not in fact the answer to this, and so I think we have a long way to go before we find an effective way of dealing with securitized debt.

Estimating the financing gap is another difficult issue. Some parts of it are pretty obvious. You can look at outstanding interbank credit or at debt outstanding, but there are other parts of it that are not so obvious: for example, how do you determine the potential for capital flight? So I think, once again, even if you think you've got your arms around the extent of the matter, I think that the answer is that it's very unlikely that you do, unless you're going to put in place capital controls. Therefore, it seems to me that what you've got to focus on, is getting the right mix of reform, official-sector money, and private-sector involvement, so that you can restore confidence, not only externally, but internally.

In terms of the structure of IMF programs themselves, my own view is that the IMF did an extraordinarily good job in the face of an extraordinarily difficult situation. The conditions in some respects were unprecedented; matters had to be decided very quickly, and you were dealing with the very complicated question of the psychology of markets.

I at least think that the IMF got it about right. It's very easy with hindsight, and if you don't have responsibility for the decisions in the face of collapsing economies, to be a critic of what was done. As I say, however, my instinct and judgment are that what was done was about the right balance. I'm not saying there shouldn't have been a little less fiscal policy in some cases; maybe in some cases there was a little too much structural reform, or maybe there wasn't, but I think that basically the judgments the IMF and the international community made were about right, and I think the proof is in the pudding, because I think in late December of 1997 and in the fall of 1998, we came very, very close to falling off a cliff in the global economy. It didn't happen, and I think it didn't happen because of what was done. Similarly, the countries that actually took ownership of reform, seemed to take ownership of reform, or at least were able to persuade people they had taken ownership of reform were able to reestablish confidence and, for the most part, to come back reasonably well, although there are certainly problems again in some of these countries.

On the question of whether or not structural reform should be part of a reform package, I guess you could make either argument on that in a conceptual, theoretical sense. But I think, as a practical matter, if structural issues are seen as having been part of what caused the problem in the first place, you're not going to reestablish confidence unless you address structural matters. My own view is that you could not have reestablished confidence in the international financial markets in Indonesia without doing something that gave people the feeling that you were addressing the issue of corruption, even though it was unlikely that whatever you were going to do 
was going to be more than moderately successful. Similarly, in almost all these situations, I don't think you would have been successful in reestablishing confidence unless the international capital markets felt that you were doing something to address structural issues. Now, as to where you draw that line, I don't have an answer. But I think, once again, it comes back to something I said in a slightly different context a moment ago, that ex ante rules are for the most part not an effective way of trying to deal with these kinds of problems. I think what you need to do in each individual situation is to make a practical judgment as to what is necessary to reestablish confidence.

What I'm about to say, I suspect, has a certain awkwardness about it. It seems to me, at least, having lived through several of these, that when crisis develops, and particularly in the world where all markets are interrelated so closely, that decisions made in each of the markets are almost instantaneously affected by what happens in other markets, that the following is so: Number one, crisis response has to be very quick. Number two, there is no assurance that any crisis response is going to work. That is to say, it's risky. Number three, politicians are risk-averse. If you accept those premises, and I think they're right, then it seems to me that this is almost surely only going to work if you have very strong leadership from the IMF, and I happen to think, as I said a moment ago, that the IMF under Camdessus, did a good job. I think you need a strong IMF, I think you need a strong leader who's willing to make gutsy decisions in full recognition that he may be criticized, and I think that you need a very small number of other countries that will be part of the process of dealing with these decisions. And I think the model we had over these last few years, of a group of G7 nations, with the United States having a particularly heavy involvement, is probably about right. You could choose a different group of nations if you want, but I think that kind of a structure is about right, because I think that as you start to get a larger number of countries and they start to debate with each other, you will not be able to move with the speed that you need to move with if you're going to deal with crisis. And the key industrial nations need to be at the core. Second, I think it has to be sheltered from a political system, because I don't think politicians for the most part are willing to take on the risks that are involved in these matters.

Another matter is industrial country macroeconomic and structural policies. One of the striking things about the Asian financial crisis was how concerned all of us were - at least, it was striking to me at the time-about whether anything would work in Asia as long as Japan was in an economic malaise. In the 1980s, as you all know better than I in many ways, the rest of the world was enormously critical of American economic policies, because of our fiscal situation and our trade imbalances. So the world is enormously affected by what happens in the major national economies or, in the case of Europe, perhaps, some collection of countries. But economic 
policy remains a sovereign matter. In the 1980s nobody could affect what the United States did, despite whatever damage we might be doing to the world, and in 1997-98, we were desperately concerned that if Japan didn't get back on track, it wouldn't be possible to reestablish confidence; nor would we have the import demand necessary to pull Asia out of this thing. There was no way to influence Japanese economic policy. I have no answer to that, except to say that this issue of the effect of the policies of the respective industrial countries on the rest of the world will probably become greater and greater as interdependence becomes greater and greater.

If you want to get a sense of how impossible the IMF's job is, just look at the paper's list of fifteen or so of the criticisms that were made of the IMF, and on each topic you can see they were criticized from diametrically opposed positions. At any event, I think there is also a tendency in these kinds of situations to come up with all kinds of ideas that are either dangerous or impractical or both. Because some of the people in this room were the sponsors of some of those ideas, I won't get into the specifics, but simply say that I do think one has to approach all suggested approaches with rigor, discipline, and a keen sensitivity to the messiness of what actually happens in these situations as opposed to what sounds attractive in some conceptual sense.

Let me conclude by saying that in my view, at least, crisis prevention is never going to be even close to perfect, but I think it can be better. I've suggested, at least in the jurisdiction of this panel, what I think should be the single most important focus of trying to make it better, although I think there are also a lot of things you could do in developing country policy as well. I also think it is inevitable that there will be future crises and I think it is possible that as we have them they will become more and more severe, because of the increases in capital flows, the increases in the speed of capital flows, the tendency of capital flows to go to larger and larger numbers of countries, with lower and lower credit quality, and also the vast increases in outstanding derivatives. And I think derivatives are an issue in the global economy that nobody's had to face yet because we haven't had a derivativecaused or substantially exacerbated crisis, but in my opinion it is likely that, sooner or later, we will have one.

With respect to crisis response, my own instinct, because I have lived through all this, is that the way these things were handled - on a case-bycase basis, and with the kinds of programs we had and the kind of mix of private-sector involvement, official-sector involvement, and reform - may be about as good as we're going to do, although it's certainly very, very important to keep looking for better ways. I also have an instinct, as I mentioned a moment ago, that we do not have effective ways of dealing with securitized debt obligations, and I think the kinds of exchange offers that have been used in the last two years (although to some extent I suppose they can be said to have worked) are unlikely to be an adequately effective mecha- 
nism, going forward. I guess the only other comment I would make is that I think there's probably more we can do on the prevention side; I'm sort of skeptical that there's a lot we can do on the response side, but I do think, as I said a moment ago, that we will almost surely have periodic crises and that they may well —on average, at least — tend to increase in severity. So I think it's enormously important that we not get complacent during good times but continue to focus on both prevention and response. Thank you.

\section{George Soros}

I should like to address some of the issues that were not addressed here today. The discussion of the international financial system has been framed in terms of the last crisis. The issues that have been addressed have been those that were raised by the last crisis: What went wrong? What can we do to prevent an occurrence of that crisis? In that context we have considered the behavior of the lenders, the behavior of the borrowing countries, and especially the behavior of the international financial institutions. Several reforms were introduced that are actually quite far-reaching, and they will be quite sufficient in my opinion to prevent a recurrence of the kind of crisis we had in 1997 and 1998. I believe the landscape has changed more radically than is generally recognized. The moral hazard inherent in International Monetary Fund (IMF) bailouts has been effectively eliminated because the private sector has suffered severe losses in countries like Indonesia and Russia. Even more importantly, it has been made very, very clear that bailouts are no longer politically acceptable. Instead of bailing out, we are now speaking of bailing in - and that means a shift of 180 degrees.

As a result of these changes, the power and influence of the IMF have been severely impaired. The emperor has no clothes as far as the markets are concerned. Because of that, the risks of investing in emerging markets have greatly increased, and the potential rewards have also diminished. The last crisis was caused by the excessive flow of capital to emerging markets. The next threat, as I see it, comes from the opposite direction-from the lack of adequate flows of capital to the capital-deficient countries at the periphery of the global capitalist system. The situation is reminiscent of the French construction of the Maginot Line after the First World War to prepare themselves for static trench warfare; but in the Second World War they were confronted by mobile warfare with tanks.

I am not so much making a prediction as I am making an observation, because the signs of inadequate capital flows are already visible. They do not show up in the published statistics about international capital move- 
ments, but they do show up in the persistent current account deficit of the United States. They are probably covered up by the large figure for errors and omissions. Since the United States has a negative saving rate, the deficit must be financed by the saving of foreigners. The international financial markets suck up the saving of the periphery countries into the center, but since the last crisis the financial markets no longer push out enough capital to the emerging markets. We can see this in the greatly widened margins that periphery countries have to pay for their borrowings and in the inferior performance of their stock markets. The emerging markets never recovered their losses from the last crisis, and they have turned down much before Wall Street. We can also see it in the substandard economic performance of periphery countries. I am thinking of countries like Bulgaria-a small country that few people pay attention to. They have actually done all the things that needed to be done, but there is no growth and people are discouraged. There is a danger that the government, which has been as good a reform government as any in the former Soviet Empire, will be rejected by the electorate at the next elections. Or take a country like South Africa, which, again, has had a really good government in terms of macroeconomic policy. Again, there is no growth, and you may well see a weakening of political will there. Countries like these could grow faster if they could attract investment, but the inflow of capital is missing. The situation is likely to get worse if and when there is an economic decline at the center. I think that the prospects of a hard landing in the United States have greatly increased in the last couple of months, so we shall see. It was quite unusual to have a crisis in the emerging markets that was not touched off by an adverse economic development at the center. If we now have such an adverse development, I believe it will aggravate the situation at the periphery. It will not necessarily manifest itself in the form of a crash, because a crash has already occurred. It is more likely to register as a depression, which could have negative political implications. So I think what is missing in our deliberations is an examination of the deficiencies of the global financial markets themselves.

The prevailing trend is to place ever greater reliance on market discipline. However, financial markets are inherently unstable, and global financial markets suffer from an additional element of instability from which the financial systems of developed countries are largely exempt. In the course of their development individual countries have learned to deal with the instability of their financial markets: they have established regulatory authorities and lenders of last resort. But the global financial system does not have a lender of last resort, and the prevailing regulatory environment is much more permissive than used to be the case before markets became globalized. Moreover, it is generally agreed that this is as it should be. The consensus among regulators is that markets are much better at regulating themselves than they themselves are at regulating markets. That is what they mean by imposing market discipline. Practically everybody is in favor of imposing 
market discipline. I feel very much like a lone voice in arguing that market discipline is not enough. I contend that greater reliance on market discipline will reveal certain deficiencies in the international financial system that are not currently recognized.

To understand these deficiencies, we must reexamine the prevailing paradigm that holds that financial markets have a built-in tendency toward equilibrium. This may be true of fish markets, but it is not true of financial markets because financial markets do not deal with known or knowable quantities: they are trying to discount a future that is contingent on how it is discounted at present. Financial markets are not just passively reflecting the so-called fundamentals; they are also actively creating them. Instead of rational expectations, market participants are confronted with a situation of radical uncertainty, in which their decisions shape the course of events. I have been told that modern economic theory has recognized this uncertainty in the form of multiple equilibria, but I am not convinced. In my view, financial markets do not necessarily tend toward equilibrium, and it is up to the financial authorities to preserve the stability of financial markets.

We have learned this lesson the hard way. Central banking and financialmarket regulation have developed in response to financial crises, but under the influence of the prevailing paradigm, which I call market fundamentalism, we seem to have forgotten this hard-learned lesson. In the past, financial crises have usually led to a strengthening of our financial institutions. After the recent crisis, the tendency has been in the opposite direction: to downsize and reduce the influence of our international financial institutions. This can be seen in the reforms already undertaken and even more in the Meltzer Report, which is the only really incisive and coherent critique of the present situation and is likely to be very influential. The systemic breakdown that occurred in the 1997-99 crisis is attributed not to the inherent instability of international financial markets but to the moral hazard introduced by the IMF-led rescue programs. "Eliminate the moral hazard" became the battle cry of the market fundamentalists.

As I said earlier, the 180-degree turn that has occurred since the inception of the last crisis will be sufficient to eliminate the moral hazard. I also believe that this is basically a desirable development because the brunt of past IMF rescue programs had to be borne by the debtor countries. However, the correction of the moral hazard problem is revealing another problem that was hitherto obscured, and that is the built-in disparity in the position of the center and the periphery of the global financial system. I call this the problem of the uneven playing field.

The playing field is uneven not only because the center consists of welldeveloped economies and the periphery is less developed; the center is rich and the periphery is poor; the center is the provider of capital and the periphery is deficient in capital. Even more important is the fact that the center is in charge of managing the system. Make no mistake about it: the sys- 
tem needs to be managed. We have wonderful, well-functioning markets because they have been well-managed. And the management is in the hands of the Group of Seven (G7), of which the United States is by far the most influential member. The IMF is very much dominated by the G7. The system is managed with the interests of the center in mind. When those interests are truly in danger, we do have the means to preserve the system. We have lenders of last resort, we have regulatory authorities, and we have managers of monetary policy. This was clearly demonstrated in October 1998 when the default of Russia threatened to disrupt the international financial markets, and all the proper actions were taken to prevent the crisis from affecting us. Reducing interest rates and bailing out Long-Term Capital Management were the key measures, and they worked. We do not have similar institutional arrangements for intervening in the case of periphery countries - even if they threaten the stability of the international financial system-because the aim of the intervention is to preserve the stability of the system, not the stability of the country in trouble. As I mentioned before, the brunt of the IMF rescue operations has had to be borne by the countries that were being rescued.

The situation will not be corrected by replacing bailouts with bail-ins because the private sector is not a charitable institution, and if it is subjected to burden sharing, it is going to charge for it. That is why the next problem will be an inadequate supply of capital to the periphery countries. The reforms that have been introduced and the changes that have occurred have increased the risks of investing in those countries and diminished the rewards. With open capital markets, the periphery countries are not in charge of their own destiny. This puts them at an inherent disadvantage with regard to the center. For instance, if the center is threatened by recession it can lower interest rates or it can stimulate the economy by fiscal measures. But a periphery country cannot afford such luxuries. It must tighten its budget and raise interest rates in order to prevent the flight of capital. Thus, the insistence on market discipline and the elimination of moral hazard renders the playing field even more uneven than it was before.

To demonstrate how important who is in charge of the system is, I should like to invoke the case of the European Exchange Rate Mechanism (ERM). The member countries did not differ much in wealth or institutional development, but the exchange rate system was in charge of the Bundesbank. After the reunification of Germany, the role of the Bundesbank as the protector of domestic monetary stability and its role as the trendsetter of European monetary policy came into conflict. The domestic considerations took precedence, as they had to, and the ERM collapsed.

I do not think that it is possible to create a level playing field, just as it is not possible to eliminate the moral hazard associated with lenders of last resort. The United States and the G7 are not going to abdicate their power and responsibility, and it would be unrealistic to expect the Federal Reserve 
to give precedence to the needs of other countries over domestic considerations. However, it is not unrealistic to insist that we should take some steps to make the playing field less uneven. It can be justified on both moral and prudential grounds. If those who are in charge cannot bring some benefits to all the members who belong to the system, then the system cannot be considered just, nor is it likely to endure.

So what could be done to make the playing field somewhat more even? I'd like to introduce two very general concepts that are currently not part of the discourse. One is to provide some economic incentives for the countries at the periphery that follow sound economic policies. Because we have a system that combines a global economy with the sovereignty of state, you can't interfere with the internal affairs of a sovereign state through punitive measures. You can do it only by offering incentives that they may voluntarily accept. If you did that, you could help to overcome many of the internal, political, and economic deficiencies that prevail in those countries. Going into the 1997-99 crisis, the IMF had practically no power to intervene until a crisis had actually occurred and a country had turned to the IMF for assistance. It is only by offering incentives that the IMF could play an active role in crisis prevention. This point has been recognized with the introduction of the Contingent Credit Line, but the emphasis on market discipline has militated against any concessions, and the Contingent Credit Line as it is currently constituted has had no takers. We need more elaborate arrangements according to which the kind of assistance that the IMF is willing to provide will vary according to the policies followed and the standards achieved by individual countries.

Second, an even more unacceptable idea is some kind of international wealth redistribution. We have a global economy, we need a global society and within a society there has to be some measure of social justice. At present, each country is supposed to pursue its own idea of social justice. But the development of global financial markets that allows capital to move around freely has impaired the capacity of individual countries to pursue their idea of social justice, because if they try to tax or regulate capital it will move elsewhere. This development has helped wealth creation but it has hindered the pursuit of social justice. Insofar as there is a need for social welfare, it can no longer be pursued on a national basis. Those who have persisted in their ideas of social justice as it could be practiced before the freedom of capital movements became universal have seen those policies fail in the new environment. That does not mean that the issues of social justice and wealth redistribution are no longer relevant. It only means that they cannot be pursued on a purely national basis. Actually, countries at the center have a much greater degree of discretion in the matter than countries at the periphery. Even so, their discretion is limited. But wealth redistribution on an international scale is simply not on the agenda. The only exception is the proposal to provide debt relief to the highly indebted under- 
developed countries. The idea has received widespread support - it is even endorsed by the Meltzer Commission - but it amounts to charity, not a recognition of the problem of an uneven playing field, and it doesn't really address the problems of these countries.

I have some ideas on how these two very general concepts could be introduced into the international financial architecture, but I do not have the time to elaborate them. Nor do I have time to discuss the vexed question of exchange rates. The point I want to make is that the current discussion is too narrow and based on the wrong premise. The most far-reaching and incisive criticism of the international financial institutions comes from the Meltzer Report, which is a document imbued with market fundamentalism, although it is tempered by a dose of charity toward the highly indebted poor countries. There is an urgent need for a similarly comprehensive assessment based on the recognition that financial markets are inherently unstable and not designed to take care of social needs. We need institutions to serve those needs, and one of the primary needs is to curb the excesses of financial markets.

\section{Discussion Summary}

Jacob Frenkel remarked that it isn't possible to prevent all crises. Indeed, the expectation of future crises - some of which we will be familiar with and some of which we won't - is a logical corollary of the creativity of markets. The proper perspective to adopt is that of risk management rather than risk avoidance. As a practical matter, this means that we should focus on eliminating distortions in the pricing of risk, thereby moving away from volatility suppression and toward volatility reduction. Returning to the issue of desirable exchange rate regimes, he emphasized that as a rule speculative attacks on currencies came when governments tried to peg the exchange rate. In current conditions it is wrong to think of international reserves as the mechanism for self-insuring against a crisis. "[I]n the new world, the selfinsurance mechanism is the development of financial markets that create the instruments to enable you to deal with [exchange rate] changes, and these markets will not develop if you insist on pegging the exchange rate," he said. On the issue of transparency, he said that "transparency about transparency"- that is, making it clear which countries publish information about the condition of the financial system - is one of the ways to encourage the development of self-insuring mechanisms.

Domingo F. Cavallo sought to clarify his statement from the session on exchange rate regimes, fearing that it was being misinterpreted. He said, "The currency system of Argentina is perfectly sustainable," and he pointed 
to the size of reserves, the ability of nationals to make deposits in foreign currencies, and the ability of banks to lend in foreign currencies as important elements in this sustainability. He went on, however, to say that we can't be sure that the current system is the final version. If Mexico had adopted the Argentine or Hong Kong system, he said, they would be converging to some kind of monetary association with the United States. He is not so sure that the Argentine system is converging to a monetary association, given that the euro and the yen are moving so much against the dollar. With Argentina's trade so diversified, at some time, possibly more than twenty years into the future, and when the Argentine exchange rate appreciates rather than depreciating, the country will move from a super-fixed to a floating regime, he said.

Regarding the problems being experienced by the Argentine economy, he said that they are not problems of overvaluation. Exports are actually growing faster than GDP. Rather, the problems are the result of destructive tax increases that have been closing off investment opportunities. This, he concluded, is not a situation you can come out of by devaluing the currency.

Andrew Crockett disagreed with Robert Rubin's pessimistic assessment that crises are inevitable and will probably become more common, finding it "profoundly gloomy in some respects." As interpreted by Crockett, Rubin's view is that this cycle of crises is inevitable because of the way markets "reach for yield and have excesses." He believes that one of the reasons for this reaching for yield is the way risk management is undertaken by institutions and reinforced by supervisors. The current practice assumes that risk falls in a boom and rises in a recession. However, it is more accurate to say that underlying risk rises in a boom and "crystallizes" in a recession. If risk management models could be made to reflect this, Crockett thought we might be able to break the trend of ever worsening crises.

Michael P. Dooley warned that he was going to be even gloomier. He said the discussion thus far had been based on the assumption that the real costs of crises come from the panic-induced breakdown of financial intermediation. He thinks that investors are smarter than that. Investors design contracts so that if they are not paid the renegotiation of the contract interferes with financial intermediation in the country. This, in turn, leads to output loss. This cost is what leads people to repay international debt, and so it is an important part of the system. If this interpretation is correct, Dooley said, involving the private sector is going to be much more difficult than suggested in models where its simply panic or bad luck that is driving the outcomes. Unless there is an alternative "enforcement mechanism," and he does not see what this might be, the threat of output loss is the one thing that makes international debt possible in the first place.

Dooley added that the ones to pay the price in the country are not the ones who have made the decisions. Residents of debtor countries suffer the loss in output while private debtors and creditors are bailed out. Referring 
to Richard Cooper's famous 1971 paper on devaluation, Sebastian Edwards interjected that the evidence is that government officials do pay the price. In the vast majority of crisis episodes Cooper studied, the finance minister or central bank governor was either fired or imprisoned, or maybe even executed. Stanley Fischer offered another calculation: of the six big recent crises the IMF has dealt with-Mexico, the three Asian cases, Russia, and Brazil - only two out of the twelve finance ministers and Central Bank governors involved survived in office following the crisis.

$E d w a r d s$ asked what mechanisms for preclassifying countries for preferential access to funds in times of crisis make sense. Based on the thinking of the Meltzer commission, he identified (without necessarily supporting) five: fiscal solvency, bank strength and supervision, participation of foreign banks, transparency, and avoiding pegged exchange rates.

Fischer responded to George Soros's call to reward countries with good policies in some way. He said that the recent changes to the IMF's Contingent Credit Line (CCL) bring it closer to what Soros suggests. However, Fischer thinks that standards and other reforms will only be effective if they affect spreads in the markets, and it is an open question how best to persuade market players to pay attention.

Arminio Fraga said that in designing any new facilities it has to be kept in mind that markets do not like discontinuities. It is fine to label countries when things are going well. But what, he asked, will be the response when a downturn comes? He favors something along the line of what Robert Rubin suggested - "some degree of ambiguity while the work is being done." $\mathrm{He}$ said this is not like the exchange rate regime debate, in which he supports the idea of extremes. The corner solutions are not practical when it comes to labeling countries. Fraga suggested that trade issues should receive more treatment in the Frankel and Roubini paper. He said the best thing that developed countries could do is to continue to work for global free trade, adding, "they should also practice what they preach."

Morris Goldstein said that Mervyn King had noted "with a tinge of pride" that the IMF now monitors sixty-six standards and codes. Recalling that in 1995 the number was zero, he said that if you want financial market participants to watch what countries are doing, they are not going to be able to watch sixty-six areas. A positive recent development is the decision by the G7 and the IMF to identify twelve as having some priority. It would have been even better, he thinks, if they had chosen six.

Yung Chul Park questioned the assertion in the paper that American capitalism has won and that the Japanese or Asian model has lost. He queried what faults they are referring to in the Japanese-Asian system. Do they mean, he asked, that relationship banking has deteriorated into crony capitalism? But this raises the question of whether the system is inherently defective or has been mismanaged by corrupt governments. He fears that "this game [of picking the superior system] will be played every four years like the 
Olympic games." He added that trying to compare the Asian model with the Anglo-Saxon model is not very productive because all the East Asian economies have market-based systems. They do have bank-oriented financial systems, but Park recalled that just a few years ago the academic community recommended this system of developing and emerging market economies. He also complained that the East Asian economies feel that they are being left out of discussions relating to reform of the international financial system. And he noted that there is considerable support among East Asian countries - including China - for the idea of some sort of Asian Monetary Fund.

Nouriel Roubini raised the issue of how more internationally mobile capital and greater derivative-driven leverage have lead to greater systemic risk. We live in a world, he said, where everyone is a mark-to-market investor, there isn't the forbearance that existed in the 1980s, and everyone is using the same value-at-risk models. With everyone acting the same way, Roubini said, we must think about the systemic effects of another liquidity shock. Continuing on the leverage theme, he said it is not obvious that greater leverage is necessarily bad. Overall leverage has contracted along with the hedge funds. But the absence of leverage - or, more importantly, the absence of these market participants - might mean that liquidity is reduced. These and other issues that have a bearing on systemic risk need to receive much more attention, Roubini said.

Jeffrey Sachs said he wanted to come back to what he saw as a shared theme in King's, Rubin's, and Soros's presentations: that incentive problems existed on both sides of the market. Yet in the final analysis, he said, the system is run by (borrowing Soros's term) the core. "This is not an international system; this is a creditor-run system," he complained. The core has a fear that any standstill will break the system. Sachs said that he has always advised countries just to stop paying when they are in a crisis-and to do so unilaterally, without waiting for permission from the U.S. Treasury.

"When that happens," he said, "the crisis eases." Moreover, when we don't allow countries to do it, they often break into pieces, like Yugoslavia did when it was told that it wouldn't get a Paris agreement back in 1990. He added that there is no real lender of last resort in the world, and "there is very little money around." As an example he pointed to Africa, where net transfers are practically zero. U.S. aid to the least developed countries is now about $\$ 600$ million, or less than six-tenths of 1 percent. Sachs ended by saying that the illusion has been created that there is little risk for the rich countries due to the fact that the imbalanced approach is being followed. But that illusion, and the bubble it may have given rise to, "is going to leave us most vulnerable ourselves." 
